\title{
Dragonflies of Dragon's Blood Island: Atlas of the Odonata of the Socotra Archipelago (Yemen)
}

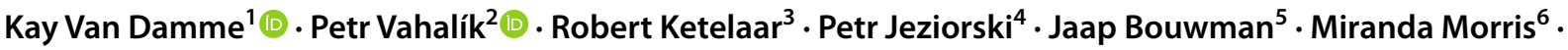 \\ Ahmed Saeed Suleiman ${ }^{7} \cdot$ Henri J. Dumont ${ }^{8}$ (i)
}

Received: 1 April 2020 / Accepted: 25 July 2020

(C) The Author(s) 2021, corrected publication 2021

\begin{abstract}
Dragonflies are important bioindicators of aquatic ecosystem health. We discuss the distribution and richness of the 22 dragon- and damselfly species known from the Socotra Archipelago UNESCO World Heritage Site (Yemen) in the western Indian Ocean. We compiled 841 records from literature, field data and museum collections, covering a surveying period of 123 years (1896-2019). Distribution of the only endemic, the Socotra Bluet Azuragrion granti (McLachlan, 1903), an indicator of pristine lotic waters, is updated. Relatively higher dragonfly species richness occurs in eastern Socotra where suitable aquatic habitats are present all year. We observed a significant drop of the number of taxa over several decades in areas in the Hadiboh Plain where human development impacts are strongest. We discuss the indigenous people's perception of dragonflies to assess the potential of these invertebrates as local flagships for aquatic biodiversity conservation. Our knowledge of the Socotran Odonata remains incomplete, yet they are now among the best studied animal groups in the archipelago. A new record of an Oriental Anax indicates that the island's dragonfly fauna may yet harbour surprises. Our compilation of odonate records is the first for Socotra and serves as a baseline for future monitoring of the archipelago's vital aquatic habitats. We converted all records into a geodatabase which we uploaded to an online, freely available web mapping server and mobile application to facilitate research and conservation of the Socotran dragonflies (www.dragonfliesofsocotra.com).
\end{abstract}

\footnotetext{
This paper belongs to a Topical Collection "Twenty years of biodiversity research and nature conservation in the Socotra Archipelago" edited by Fabio Attorre and Kay Van Damme, conceived at the 18th Friends of Socotra Conference, 26-29 September, 2019, Orto Botanico di Palermo, Palermo, Italy".

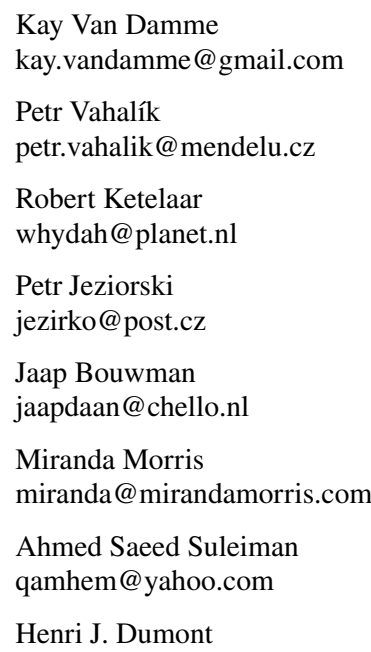

1 Senckenberg Research Institute and Natural History Museum Frankfurt, Senckenberganlage 25, 60325 Frankfurt am Main, Germany

2 Department of Forest Management and Applied Geoinformatics, Mendel University in Brno, Zemědělská 1, Brno 613 00, Czech Republic

3 Rhienderinklaan 25, 7231 DB Warnsveld, The Netherlands

$4 \quad$ Na Bělidle 1, Haviŕrov-Suchá 735 64, Czech Republic

5 Huissensestraat 85, $6833 \mathrm{HM}$ Arnhem, The Netherlands

6 University of Saint Andrews, St Andrews, UK

7 Environmental Protection Agency, Socotra Branch, Hadiboh, Socotra Governorate, Yemen

8 Department of Biology, Ghent University, K.L, Ledeganckstraat 35, 9000 Ghent, Belgium
} 


\section{Graphic abstract}

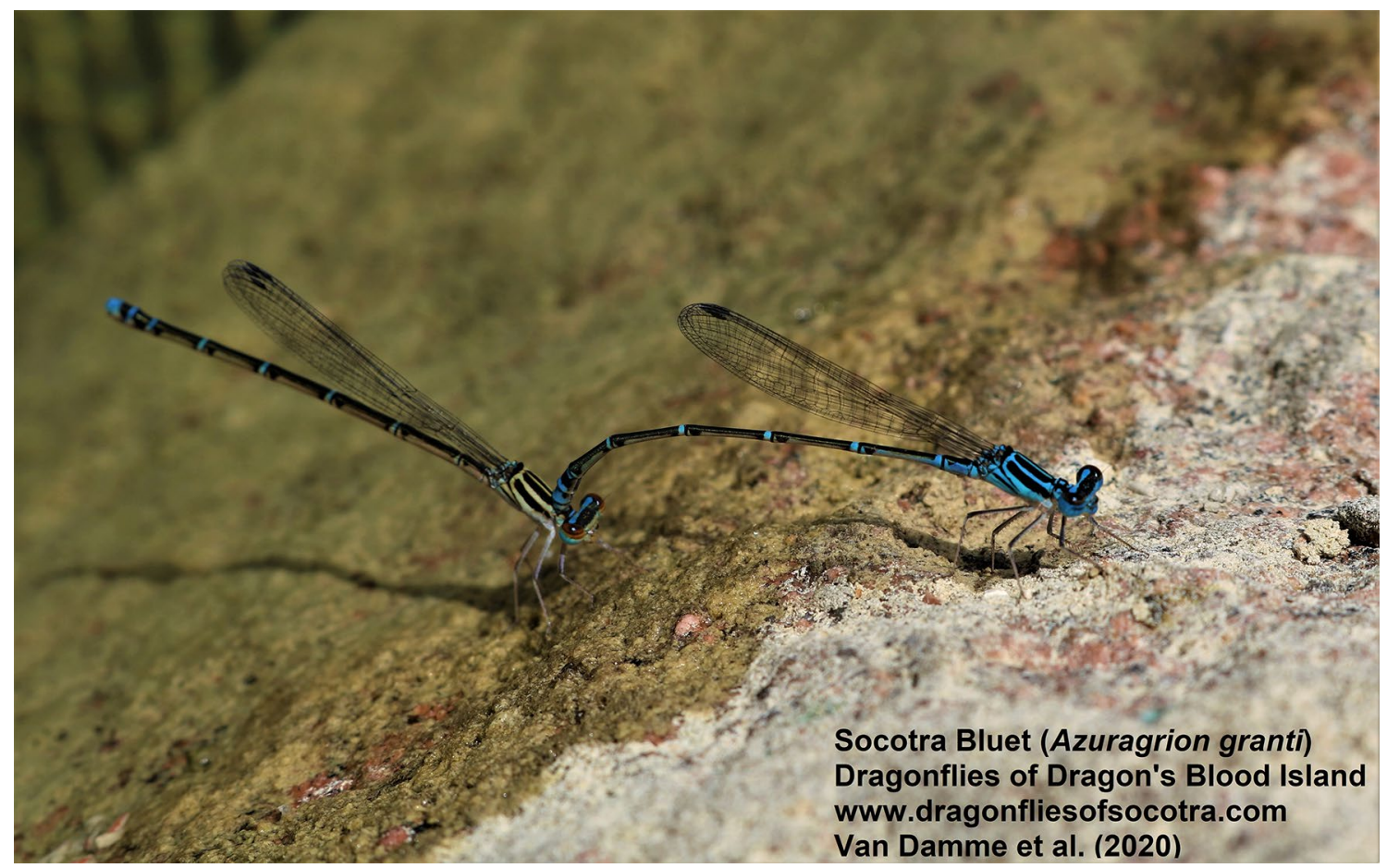

Keywords Odonata $\cdot$ Socotra Archipelago $\cdot$ Distribution $\cdot$ Aquatic habitats $\cdot$ Biodiversity $\cdot$ Richness

\section{Dedication}

This paper is dedicated to the late Dr. Wolfgang Schneider, an exemplary researcher known for his kindness and professionality. Wolfgang has been a dear friend and an excellent odonatologist who contributed for decades to freshwater conservation in the Arabian Peninsula. His interest in the biodiversity of Yemen and Socotra, and his undying love for the dazzling dragonflies, will not be forgotten.

Their displays of contrasting colours and aerial acrobatics have endeared them to scientists and laymen alike (Schneider and Samraoui 2015).

\section{Introduction}

The Socotra Archipelago (Yemen), a UNESCO Natural World Heritage Site just off the Horn of Africa, is well known for its high levels of endemism and biodiversity (Miller and Morris 2004; Cheung and DeVantier 2006). The archipelago, totalling a land surface of about $3800 \mathrm{~km}^{2}$, is situated ca. $240 \mathrm{~km}$ east of Somalia and $380 \mathrm{~km}$ south of the Arabian mainland; it consists of four islands, of which Socotra Island is the largest, constituting about $95 \%$ of the total land mass. The granite basement forms a microplate, continental in origin, that dates back to the Palaeozoic; the archipelago was situated adjacent to Oman until the oceanic phase of the Gulf of Aden rifting in the Oligo-Miocene (Cheung and DeVantier 2006). The maximum altitude is ca. $1540 \mathrm{~m}$ in the granitic Hageher mountains, yet most of the land surface consists of elevated karstified limestone plateaus bordered by coastal lowlands (Beydoun and Bichan 1970). The archipelago is situated in the intertropical convergence zone and therefore subjected to monsoon seasons that create temporary isolation from visitors and a partly tropical climate at higher elevations, although the lowlands and the plateaus are predominantly arid (Miller and Morris 2004; Scholte and De Geest 2010). The ancient former connection to the AfroArabian mainland and the varied topography combined with the monsoonal weather system result in high biodiversity and endemism, in particular in wet refugia in the mountains (Wranik 2003; Miller and Morris 2004; Van Damme 2009; Banfield et al. 2011; Van Damme and Banfield 2011; Bezděk and Hájek 2017).

The surface waters of this small island group in the western Indian Ocean are relatively low in biodiversity when compared to the terrestrial environment; the Socotra Archipelago has been distinguished as its own freshwater ecoregion with a depauperate yet endemic freshwater invertebrate 
fauna (Thieme et al. 2005) and has the only Ramsar wetland in Yemen (Ramsar 2013). However, the aquatic habitats contain remarkable endemic invertebrates including molluscs, insects and crustaceans, such as the IUCN Red Listed freshwater crab Socotrapotamon socotrensis (Hilgendorf, 1883) (MacLachlan 1903; Apel and Brandis 2000; Fikáček et al. 2012; Hájek and Reiter 2014). The land on Socotra faces a wide range of challenges including pollution, overgrazing, climate change, water extraction and infrastructure developments, all of which may negatively affect the aquatic environment as well (Wranik 2003; Thieme et al. 2005; Van Damme 2011; Van Damme and Banfield 2011; Neubert et al. 2014; IUCN WH Outlook 2017).

To protect the surface waters of Socotra, selecting bioindicators and priority areas is key. Odonata are a major flagship group, increasingly used as sentinels of aquatic ecosystem stability and global warming, as these insects respond rapidly to environmental changes in both aquatic and terrestrial habitats (Clark and Samways 1996; Clausnitzer and Jödicke 2004; Kalkman et al. 2008; Simaika and Samways 2009; Dolný et al. 2011; Samways and Simaika 2016). Pollution, habitat destruction and exotic species may have a significant effect during the aquatic life stages of Odonata, while adults are susceptible to alterations in the terrestrial environment, such as the presence of littoral vegetation (Remsburg and Turner 2009). In particular in arid regions such as in the Arabian Peninsula, human impacts on dragonfly habitats are of grave concern (Krupp et al. 1990; Schneider and Samraoui 2015). In addition, extreme climatic events, including cyclones which in recent years had severe impacts on Socotra, are likely to have an impact on insular populations of dragonflies (Clausnitzer and Martens 2004). For conservation on islands, vulnerable dragonfly species should be highlighted (Clausnitzer and Martens 2004); equally important is focusing on areas with high dragonfly diversity, identifying threats and priority sites (Samways et al. 2011).

Ecosystem services of dragonflies include a wide range of benefits to humans, such as their potential impacts as predators of invertebrate disease vectors, as well as aesthetic benefits (May 2019). In addition, being charismatic colourful insects, dragonflies play a role in conservation, recreation and ecotourism in many countries as iconic flagship species for the aquatic environment (Lemelin 2007). Their role as 'guardians of the watershed' cannot be ignored (Clausnitzer and Jödicke 2004). Being attractive to visitors, dragonflies therefore have a socioeconomic impact in several regions by supporting the conservation of key habitats (Walpole et al. 2002). In the Arabian Peninsula, Odonata are considered one of the few invertebrate groups that serve as ambassadors for freshwater conservation (Schneider and Samraoui 2015).

Odonata are one of the best studied insect groups in the Socotra Archipelago (Batelka 2012; Bezděk and Hájek 2017). They include some of the few Socotran insect populations for which sequences are available, i.e. nuclear ribosomal markers of two species of Azuragrion May 2002 (Samraoui et al. 2002; Dumont et al. 2010). The first Socotran Odonata have been collected as part of the earliest faunistic surveys on the island around the end of the nineteenth century (McLachlan et al. 1898; 1903). These early works on the Socotran species are among the first detailed Odonata studies in the entire Arabian Peninsula (Schneider and Samraoui 2015). In the outer islands Samha, Darsa and Abd al Kuri, the first dragonfly surveys were carried out only later, starting in the 1980s and 1990s (Schneider and Dumont 1998; Wranik 2003; Scheider and Nasher 2013). Odonata are common in a wide range of surface waters in Socotra, in wadis, temporary pools, estuaries, lagoons and man-made water reservoirs (Schneider 1999; Schneider and Dumont 1998; Nasher and Al Jumaily 2003; Wranik 2003; Riservato et al. 2010). The current species tally of the archipelago's dragonflies and damselflies can be considered as near to complete (Schneider and Nasher 2013). Depictions of Socotran Odonata can be found in McLachlan (1903) and in Wranik (2003), however with outdated taxonomy.

Compared to other archipelagos of similar size, Socotra has a relatively poor odonate fauna (Schneider and Dumont 1998; Schneider and Nasher 2013). A total of 21 species belonging to 15 genera and five families have been recorded from the archipelago before the current study (Schneider and Dumont 1998; Riservato et al. 2010; Schneider and Nasher, 2013; Bezděk and Hájek 2017). The single endemic species Azuragrion granti McLachlan, 1903, Grant's Bluet or Socotra Bluet (Zygoptera: Coenagrionidae), has been assessed as Near Threatened in the IUCN Red List (Schneider et al. 2018). It is one of seven Odonata taxa endemic to the Arabian Peninsula (Schneider and Samraoui 2015). The Phantom Flutterer Rhyothemis semihyalina (Desjardins, 1832) (Libelullidae) is no longer found in the island (Kimmins 1960; Riservato et al. 2010; Van Damme and Banfield 2011), and the only recorded extinction of local populations of an invertebrate from Socotra so far. The most recent tally of locally extant taxa is therefore 15 Anisoptera and 5 Zygoptera (Schneider and Nasher 2013). The majority of the species are Afrotropical, a few are Paleotropical, Oriental or widespread migrants (McLachlan 1903; Dumont 1991; Schneider and Dumont 1998; Schneider and Nasher 2013). The dragonfly species composition of Socotra is quite similar to that of Oman, in particular to Dhofar (Schneider and Dumont 1998) although the latter area harbours more species (Lambret et al. 2017).

The goal of this study is to provide a comprehensive baseline of the distribution of the Odonata of Socotra based on the available literature, field data and museum collections. We include general ecological notes from field observations and discuss perception of the indigenous people towards these animals. Because Odonata are a useful group for monitoring aquatic habitats, we examine their distribution and richness 
over time to identify changes and priority areas for conservation. In addition, we update the knowledge on the distribution of the endemic Socotra Bluet A. granti and we include a note on one new record of an Oriental Anax.

\section{Material and methods}

\subsection{Distribution records}

We compiled distribution records of the Socotran Odonata from available literature, augmented by unpublished records from museum collections and field surveys. The data are herein available as electronic supplementary material and under the Socotra Dragonfly Portal (see Online Resources). Literature records span a surveying period from 1896 to 2010; additional records include unpublished field data up to 2019 (e.g. surveys Ketelaar et al. 2009-2010, survey KVD 2019). There is a 30-year gap in the records; the first record after 1956 is in 1988. All records are from the period October to April, as the archipelago is difficult to access for researchers from outside during the monsoon period (May-September) and no local monitoring is carried out yet. All records were checked for geographical accuracy and only reliably identified records were included; even though adult dragonflies may fly far from aquatic ecosystems, the records generally reflect the presence of suitable habitats on the island close to each observation during the surveying period (Oct-Apr). Records with vague or unidentified localities were excluded; for toponyms that could be identified in older literature (McLachlan 1903; Kimmins 1960) we used Bezděk et al. (2012) to infer the nearest coordinates. Specimens collected by Wranik deposited in the National Museum of Prague, identified by Jeziorski, lack coordinates; for these records, the localities are an approximation after direct correspondence and agreement with Dr. Wranik. For specimens labelled with the toponym "Diksam" in the latter collection, which forms part of the central high limestone plateaus in Socotra, we placed the locality along the courses of Wadi Ziyreg, confirmed as the main aquatic collection site by Dr. Wranik in the area, at the point where the main road cuts through the wadi (Wranik
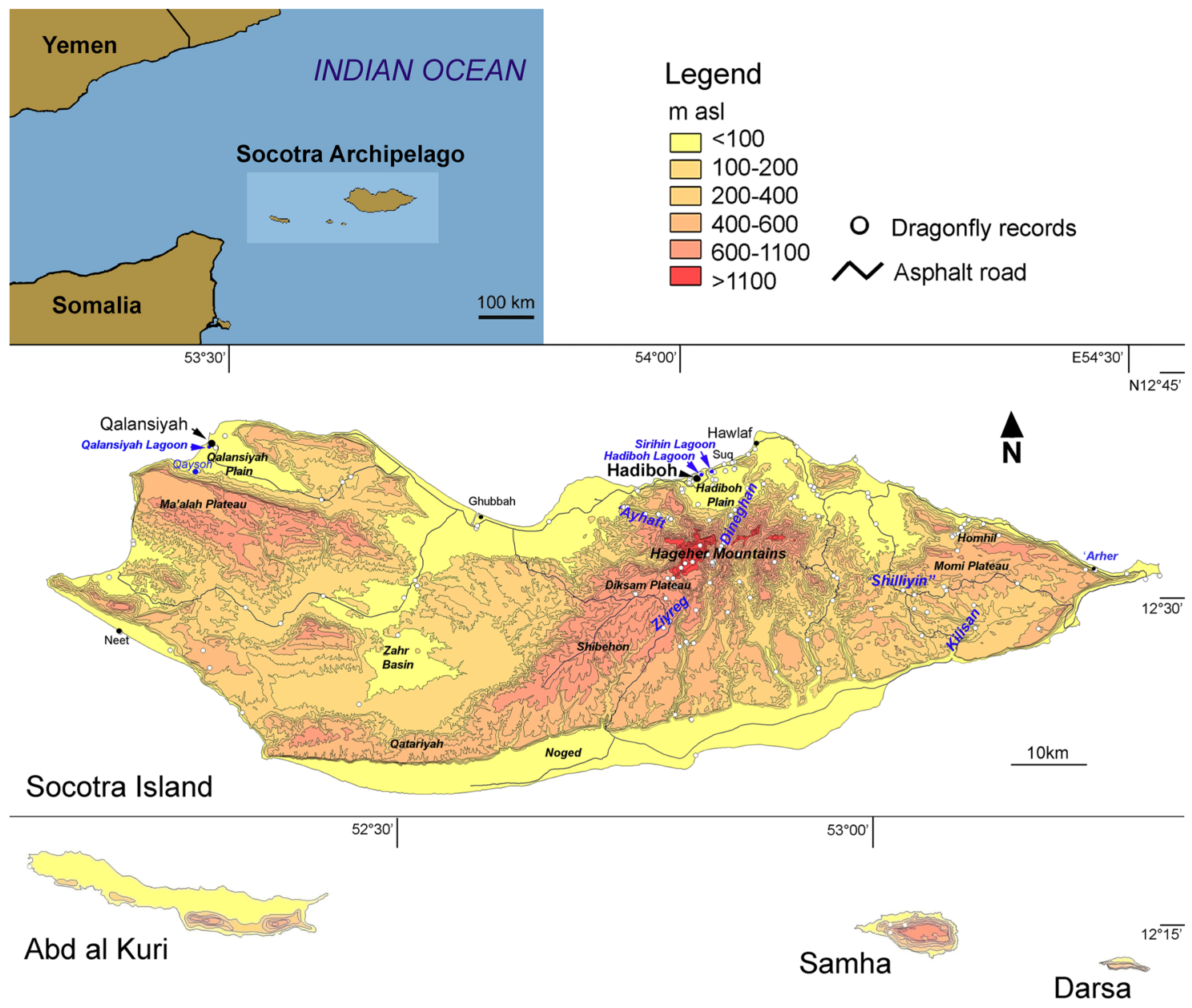

Fig. 1 The Socotra Archipelago (Yemen). Empty circles show all dragonfly localities included in this study, covering a survey period from 1896 to 2019 
pers. comm. 2020). In total, 841 reliable records of the Socotran Odonata were collected in our database covering a surveying period 1896-2019. Species distribution and richness were visualized using DIVA-GIS version 7.5, the latter using the simple point-to-grid procedure (spatial resolution 0.05 ) and number of different classes as output (Hijmans et al. 2001).

For comments on local habitats we used field observations from our surveys in Socotra. Extra information per record is included in the electronic supplementary material and the Socotra Dragonfly Portal. The study area and key localities referred to in the text are shown in Fig. 1. Information on the language and local culture was compiled by M. Morris during local interviews showing photographs of dragonflies in the 1980s and 1990s (partly published in Wranik 2003) and updates and additions collected by KVD, working with Socotri speakers Ali Yahia Mahroos and Salem Hamdiah during surveys in 2019 and 2020.

\subsection{Toponyms}

Local toponyms occur in different spellings in entomological papers (Bezděk et al. 2012) due to the challenging transcription of the unique Socotri (Sokotri-Soqotrii) language. English transcription (and phonetically correct transcription between parentheses) of the most common toponyms used in the text are provided here by M. Morris: 'Adho di-Meleh, mountain pass near the upper course of Wadi Dineghan ( ${ }^{(} \bar{A} \mathrm{dho}$ di-Mēla; the /'/ to signal the letter / $/$ / which is missing in English), 'Arher spring ('Árher), 'Ayhaft wadi ('Ayhaft), Di-Degub cave (Di-Dēgub), Di-Hāmis wadi (Di-Hāmis), Diksam plateau (Díksam), Dineghan wadi (Di-Négəhan), Dirhur wadi (Dírhur), Hadiboh town (Hadiboh), Hageher mountains (Hagher), Homhil area and wadi (Hōmhil), Kilisan wadi (Kilísan), Ma'ābadh wadi (Ma`āassoś), Ma'nefo wadi (Ma`néfo), Momi (Mōmi), Qadhub village (Qāșab), Qalansiyah town and wadi (Qalansiyah), Qariyah lagoon (Qariyah), Qaysoh wetland (Qíssoh), Qishn area and wadi (Qishn), Shu'ub wadi and mangrove (Śyácab/ Syúcub), Sirihin lagoon and wadi (Sírihin), Suq settlement and wadi (Shiq), Ziyreg wadi (Zīreg; often in literature as Zerik). The location of several key toponyms are shown in Fig. 1.

\section{Results}

\subsection{Species accounts}

\section{Zygoptera-Damselflies Coenagrionidae-Pond Damsels}

\section{Azuragrion granti (McLachlan, 1903)—Grant's Bluet or Socotra Bluet}

(Fig. 2a, b habitus; Fig. 3 map; Fig. 4a, b as prey)
Only known endemic Socotran odonate (Fig. 2a, b). Restricted to Socotra Island, not in the outer islands (Fig. 3). See May (2002) for revision of the genus Enallagma Charpentier, 1840. Azuragrion granti is found between 0 and $1200 \mathrm{~m}$ altitude, but typically above $300 \mathrm{~m}$ (Fig. 3). Restricted to freshwater, never in brackish environments. With a total of 69 records in our database (8\% of the total records), A. granti is a relatively common species in Socotra, but it is not widespread. The species is restricted to the eastern half of the main island (Fig. 3) where it is typical for flowing freshwater ecosystems and often occurs in sheltered, well-vegetated surroundings. The Socotra Bluet is primarily a mountain endemic of permanent lotic systems; it ventures down to sea level along the deep valleys leading down from the Hageher, the central mountain range in Socotra. Prefers more fast than slow flowing waters (but present in both) where it is locally abundant (Fig. 2b), sometimes around deep clear wadi pools. Commonly seen at Wadi 'Ayhaft, Ziyreg, Dirhur and Dineghan. Also recorded from several localities in the east that are not directly connected to mountain valleys. For example, Guichard (in Doe 1992) mentions A. granti from the wadi pools at the escarpment in Homhil. We found the species in a small shallow sheltered stream running through a date palm plantation in the coastal plain in the northeast, at the foot of the limestone escarpments of the Halah area (Wadi Dhamr, just south of the village Rosh). Adults often seen in tandem (sometimes under water), on boulders and in littoral vegetation. Not a strong flyer. The nymphs are abundant on submerged rocks, mostly in clear flowing waters and in large clear wadi pools, where they live freely on boulders. Often found in the same habitat as the endemic freshwater crab Socotrapotamon socotrensis.

Azuragrion granti disappeared in several localities in the northern lowlands. In the 1950s, the species occurred in the Hadiboh Plain (Fig. 3), recorded here by G. Popov in 1953 (Kimmins 1960). Popov's record is from Wadi Ma'nefo, a stream which runs from the foothills southwest from Hadiboh through the city, towards the sea. The locality is listed as "Hanifu" in Kimmins (1960), for coordinates see "Manifo" in Bezděk et al. (2012) and the map in Wranik (2003); we estimate this locality along the wadi between the foothills and Hadiboh. We consider two specimens collected by D. Botting during the Oxford Expedition to Socotra from a locality labelled "Kishem" in 1956, as originating from between the western foothills towards the central area of the Hadiboh Plain; the record by Botting from the collections at the Natural History Museum in London has been hitherto unpublished. His toponym Kishem corresponds to an area and a stretch of Wadi Dineghan (Wadi Di Negehen) when it arrives from the foothills and flows through the lowlands towards an area between Hadiboh and Suq (map in Wranik 2003); the watercourse is called Wadi Qishn in this area, from which the stream continues further north to 

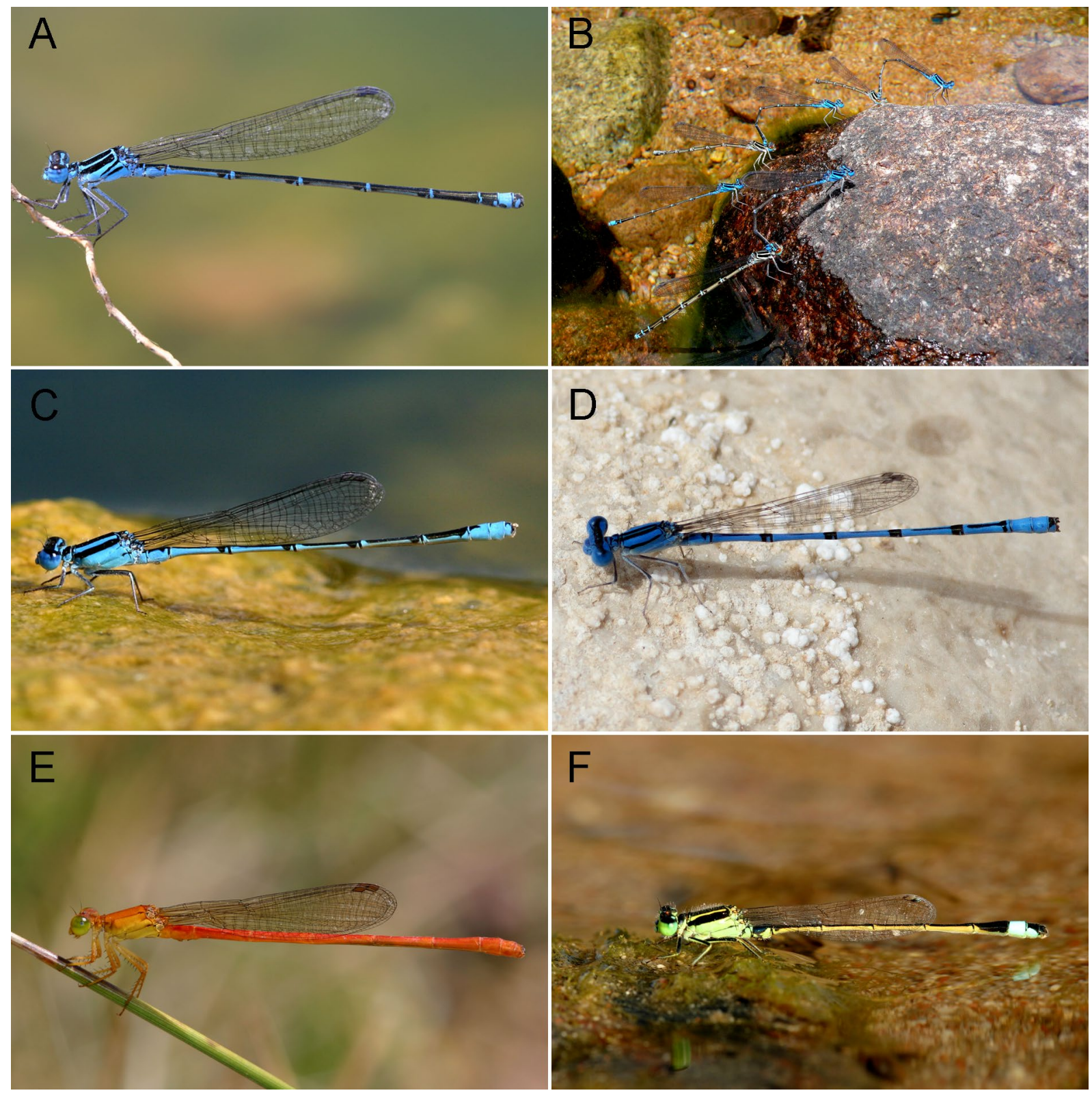

Fig. 2 Coenagrionidae (Zygoptera) from the Socotra Archipelago (Yemen). a Azuragrion granti male; b Azuragrion granti male and female, in tandem; c Azuragrion nigridorsum male; d Azuragrion somalicum amitinum male (not from Socotra); e Ceriagrion glabrum male; F. Ischnura senegalensis male. a photo R. Ketelaar, Di-Hashus, Socotra Island, 26-02-2009, b photo R. Ketelaar, Wadi 'Ayhaft,

the coast as an estuary connecting to Sirihin Lagoon as it becomes Wadi Sirihin (see also Bezděk et al. 2012). A map by A. Spark in the account of the Oxford Expedition by Botting (1959) shows an approximation of the village Kishin (Qishn) towards the foothills of the Hadiboh Plain; we estimated the record between the village itself and further north along the courses of Wadi Qishn as depicted in the map by Wranik (2003). Azuragrion granti was also recorded in 1953 from "Moaddhab" (Kimmins 1960), a locality which

Socotra Island, 22-02-2009, c photo P. Schrijvershof, Wadi Ash Shuwaymiyah, Oman, 26-02-2016, d photo R. Ketelaar, Wadi Shilliyin, Socotra Island, 25-02-2009, e photo R. Ketelaar, Ridah, Momi, Socotra Island, 24-02-2009, f photo R. Ketelaar, lagoon at Suq, Socotra Island, 20-02-2009

can be identified as Ma'ābadh, a lowland area and wadi $10 \mathrm{~km}$ directly east from the centre of Hadiboh (Maabad in Bezděk et al. 2012); the latter locality is situated near to where W.R. Ogilvie-Grant recorded A. granti in 1898 at Wadi Di-Hāmis (McLachlan 1903) (Dahamis in Bezdĕk et al. 2012). It is possible that the species is still present in some waters at the foothills of the Hadiboh Plain or foothills in the Ma'a badh area, but we found no records to suggest the presence of the Socotra Bluet in the latter lowlands since 

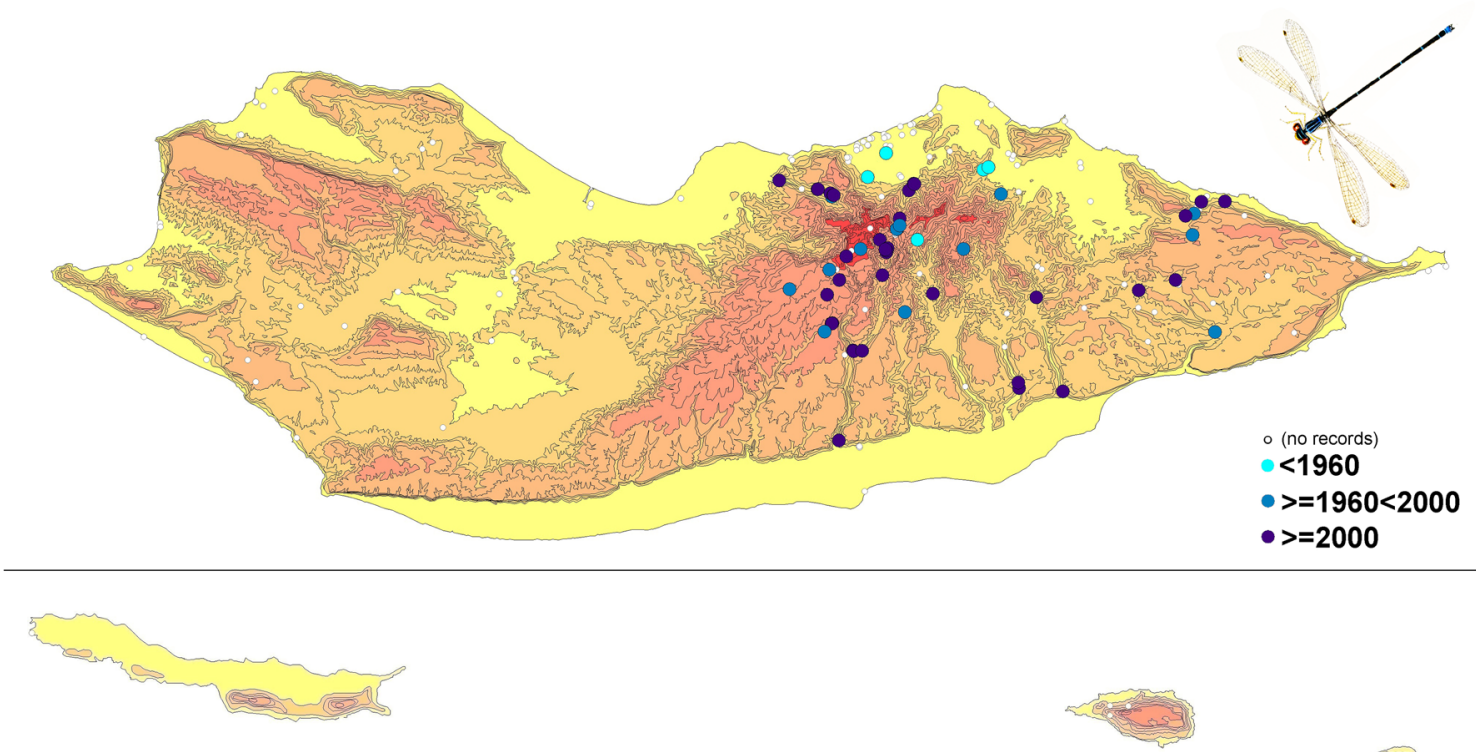

\section{Azuragrion granti (McLachlan, 1903) - Socotra Bluet}

Fig. 3 Distribution of the endemic Azuragrion granti in the Socotra Archipelago (Yemen) based on records from 1896 to 2019. White circles indicate surveyed localities lacking records for this species
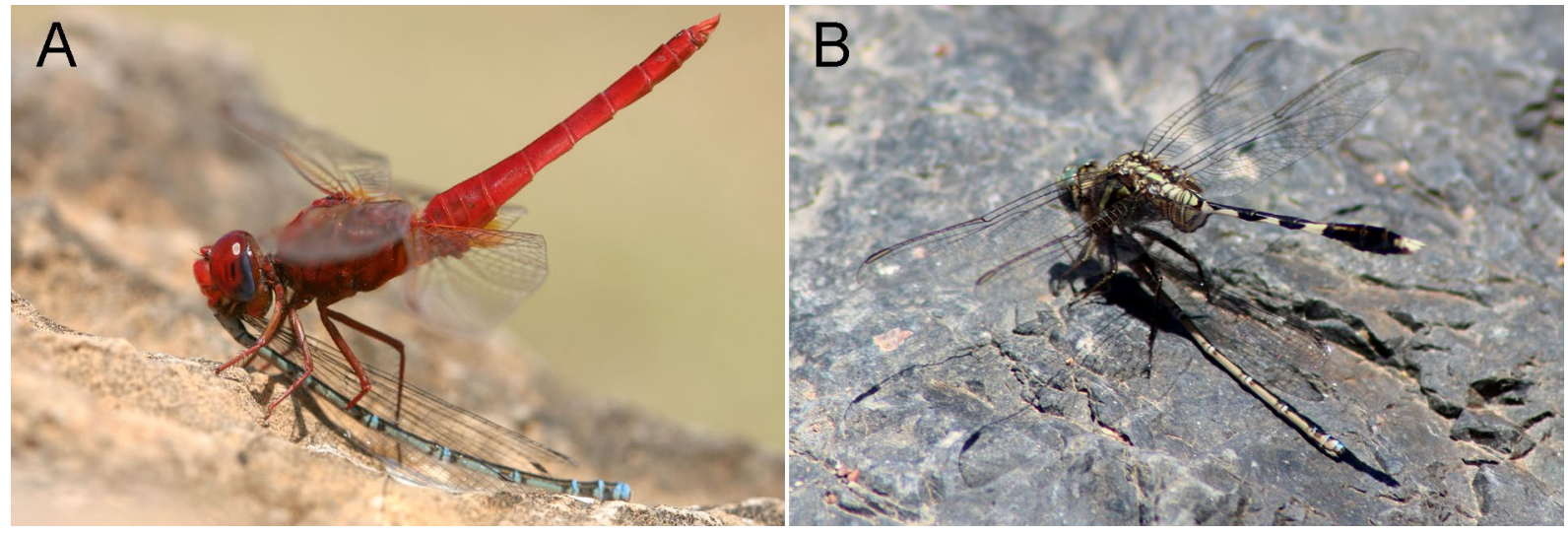

Fig. 4 Azuragrion granti as prey for other Odonata, Crocothemis erythraea (a) and Orthetrum sabina (b). a photo R. Ketelaar, Wadi Ziyreg, Socotra Island, 21-02-2009, b photo K. Van Damme, Wadi Ziyreg, Socotra Island, 04-2019

1956. In the high mountain areas, A. granti was recorded first in 1898 (McLachlan 1903).

We estimate that the total area of occupancy of A. granti may have therefore shrunk ca. $100 \mathrm{~km}^{2}$ since its disappearance in the Hadiboh and Ma' ābadh areas; currently, we estimate the known area of occupancy at about $800 \mathrm{~km}^{2}$, about a fifth of the total surface of Socotra island. Comparison of records of 1960-2000 and 2000-2019 (Fig. 3) suggests more observations south and east of the Hageher mountains since 2000. This is an artefact that we attribute to a larger number of odonate surveys in the southern and eastern areas in the last 20 years, such as the records by Riservato et al. (2010); it is likely that the species existed here before as well. Before 2000, these areas were harder to access due to the absence of the now extensive road network in Socotra (Fig. 1). The most western record of $A$. granti is in the lower stretches of Wadi 'Ayhaft, a valley connected to the high mountains.

We observed that $A$. granti, as a slow flyer that is often locally abundant, is a common prey for other Odonata. We observed predation by the Libellulidae Crocothemis erythraea (Fig. 4a) and Orthetrum sabina (Fig. 4b). 


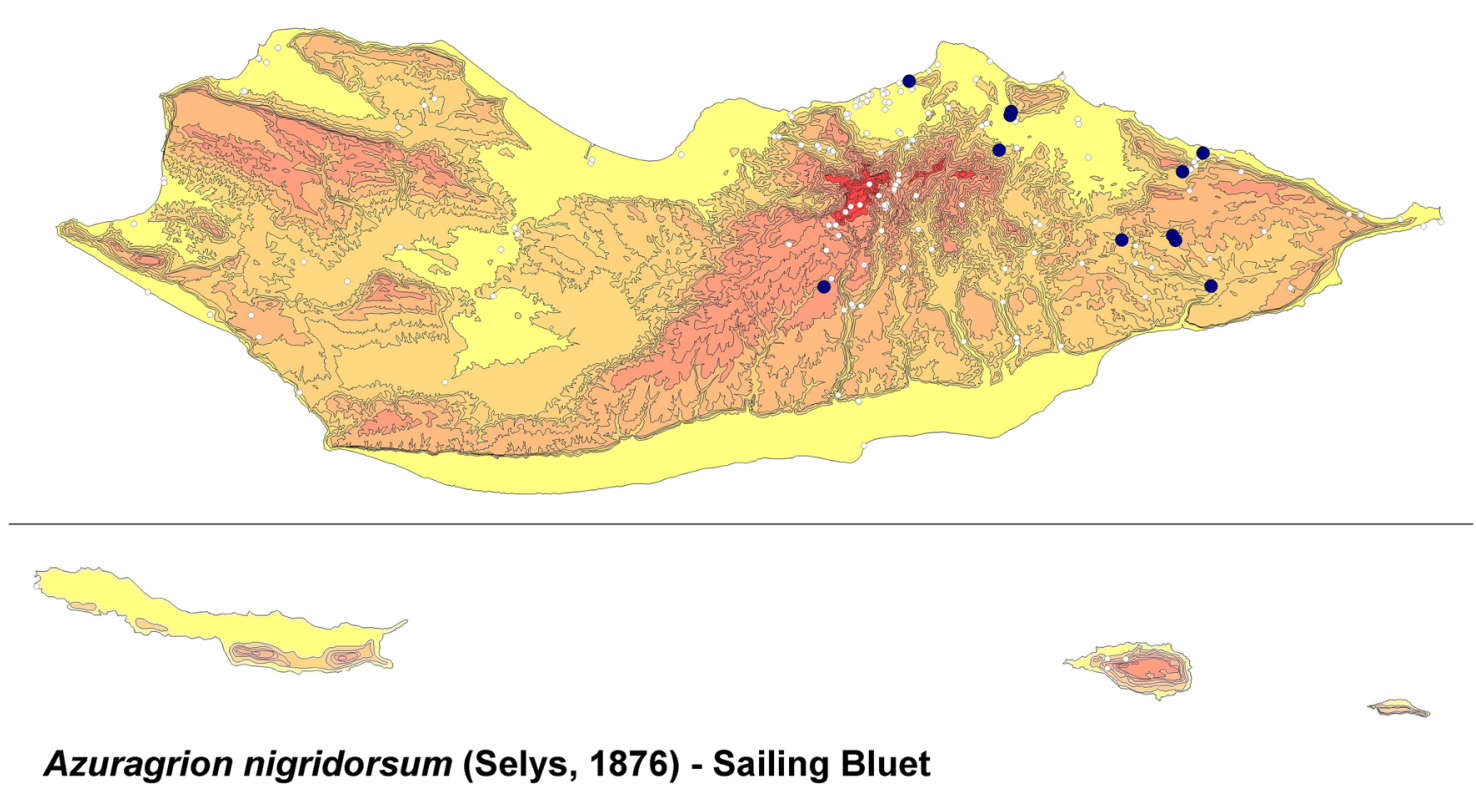

Fig. 5 Distribution of Azuragrion nigridorsum in the Socotra Archipelago (Yemen)

\section{Azuragrion nigridorsum (Selys, 1876)—Sailing Bluet}

(Fig. 2c habitus; Fig. 5 map)

A rare species in Socotra (Fig. 2c), only 12 observations or $1.4 \%$ of the total. Not on the outer islands. Azuragrion nigridorsum is only found in the north-eastern quarter of Socotra Island (Fig. 5), recorded from several wadis in lowland areas along the coast and in waters on the Momi and Diksam plateaus from sea level up to $600 \mathrm{~m}$. Total area of occupancy before 1960 in Socotra is about $480 \mathrm{~km}^{2}$ and $420 \mathrm{~km}^{2}$ after. All localities, except one in Diksam, are at 0-300 m elevation. The most southern record is in Wadi Kilisan. In 1898, W.R. Ogilvie-Grant collected A. nigridorsum from the Hadiboh Plain (as Ischnura n.sp. in McLachlan 1903); however, the species has not been recorded in this area since. Breeding was observed in Wadi Shilliyin in Momi, where A. nigridorsum occurs in large numbers. The species can be confused with A. granti in the field (Figs. 2a, b); however, the body of A. nigridorsum is distinctly shorter in comparison (Fig. 2c). In addition, the antehumeral stripe is connected posteriorly to blue on the mesepimeron in A. granti, while it is separated from mesepimeral blue by a complete black humeral stripe in A. nigridorsum; only abdominal segment S9 is largely blue in A granti, while S8-9 are largely blue in A. nigridorsum.

In the higher areas such as the Hageher mountains, $A$. nigridorsum seems to be replaced by $A$. granti; distributions of both species overlap only in Momi and Homhil (Figs. 3, 5). The Sailing Bluet does not occur on Socotra in fast-flowing streams which are more typical for A. granti, instead the males can often be seen on clumps of floating algae and grassy vegetation along slow flowing streams and in marshes. Schneider (1999) described on Socotra how A. nigridorsum males "fly close to the water upstream, rest on it to float downstream and then take off again". The species ranges from sub-Sahel Africa and Madagascar to southern Arabia (Dumont 1991); it has a disjunct distribution in Arabia, occurring in southern Arabia only in two areas in the mainland of Yemen and Oman (Dhofar) and in Socotra Island (Schneider and Nasher 2013; Lambret et al 2017). See May (2002) for the separation of A. nigridorsum from Enallagma.

\section{Azuragrion somalicum Longfield, 1931 ssp. amitinum Waterston, 1991—Somali Bluet}

(Fig. 2d habitus; Fig. 6 map)

Extremely rare on Socotra Island (Fig. 6). Not in the outer islands. Recorded only once, collected by KVD in 1999 (Schneider and Nasher 2013) at ca. $900 \mathrm{~m}$ altitude in the Diksam plateau towards the Hageher mountains at Skand, in a sheltered well-vegetated shallow marsh. The species may be more common in marshes and small wetlands in the high altitude areas of the Hageher Mountains of Socotra; however, without close examination in the field, this species (Fig. 2d) may be confused with the other bluets of Socotra. The subspecies A. somalicum amitinum has a very small area of occupancy globally, occurring in Dhofar in Oman (Waterston and Pittaway 1991; Schneider and Ikemeyer 2016; Lambret et al. 2017), Socotra and South Yemen, only known from a few localities (Schneider et al. 2013; Schneider and Nasher 2013). It can be considered as very rare throughout its range; the 


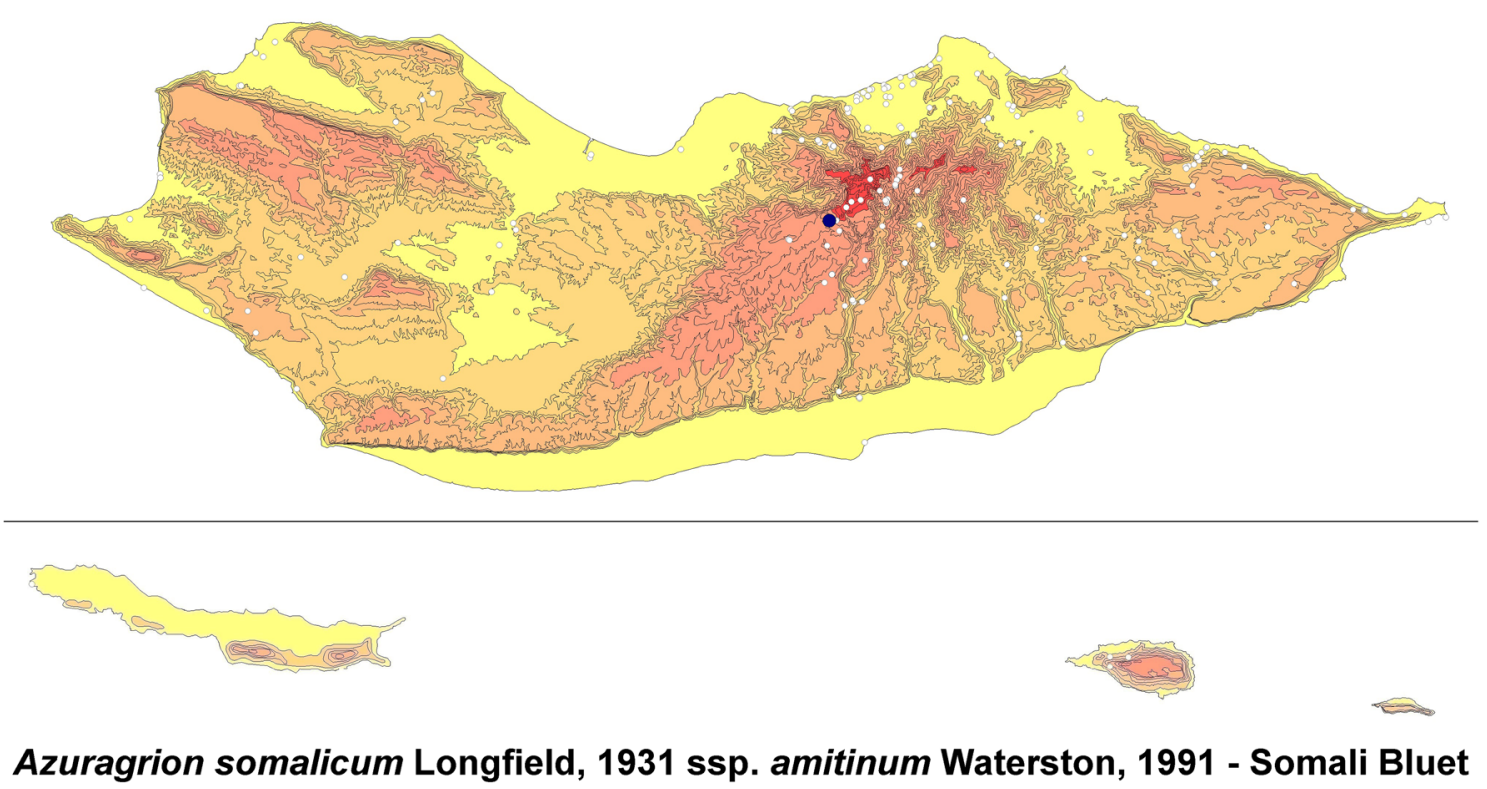

Fig. 6 Distribution of Azuragrion somalicum amitinum in the Socotra Archipelago (Yemen)

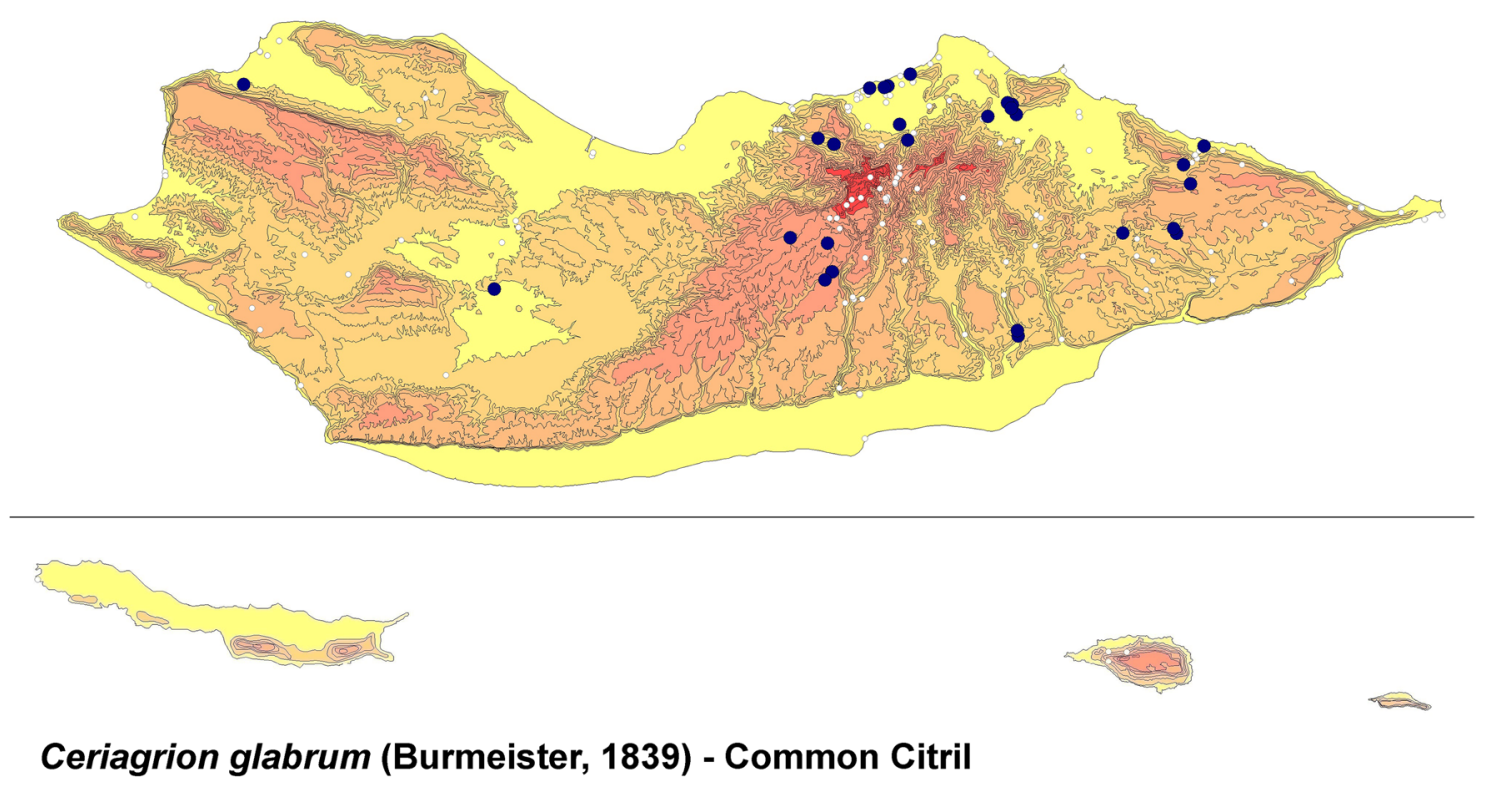

Fig. 7 Distribution of Ceriagrion glabrum in the Socotra Archipelago (Yemen)

status of this taxon needs closer investigation (Schneider and Nasher 2013). See May (2002) for revision of Enallagma.

\section{Ceriagrion glabrum (Burmeister, 1839)—Common Citril}

(Fig. 2e habitus; Fig. 7 map)

Widespread in Socotra (Fig. 7), not common (4\% of the records) but locally abundant. Not in the outer islands. The species is found in brackish lagoons, in lakes and in freshwater wadis and marshes, often on grassy banks and macrophytes, on clumps of floating algae in lagoons and along slow flowing waters, between 0 and $900 \mathrm{~m}$ altitude; not recorded from the highest central areas in the mountains. Occurs in the Hadiboh Plain at Sirihin and Hadiboh Lagoons, found here during the first dragonfly surveys (McLachlan et al. 1898; McLachlan 1903) and still found in this area today. Along wadis on the Momi and Diksam plateaus, especially in areas with low grassy vegetation. In other regions, such as in 


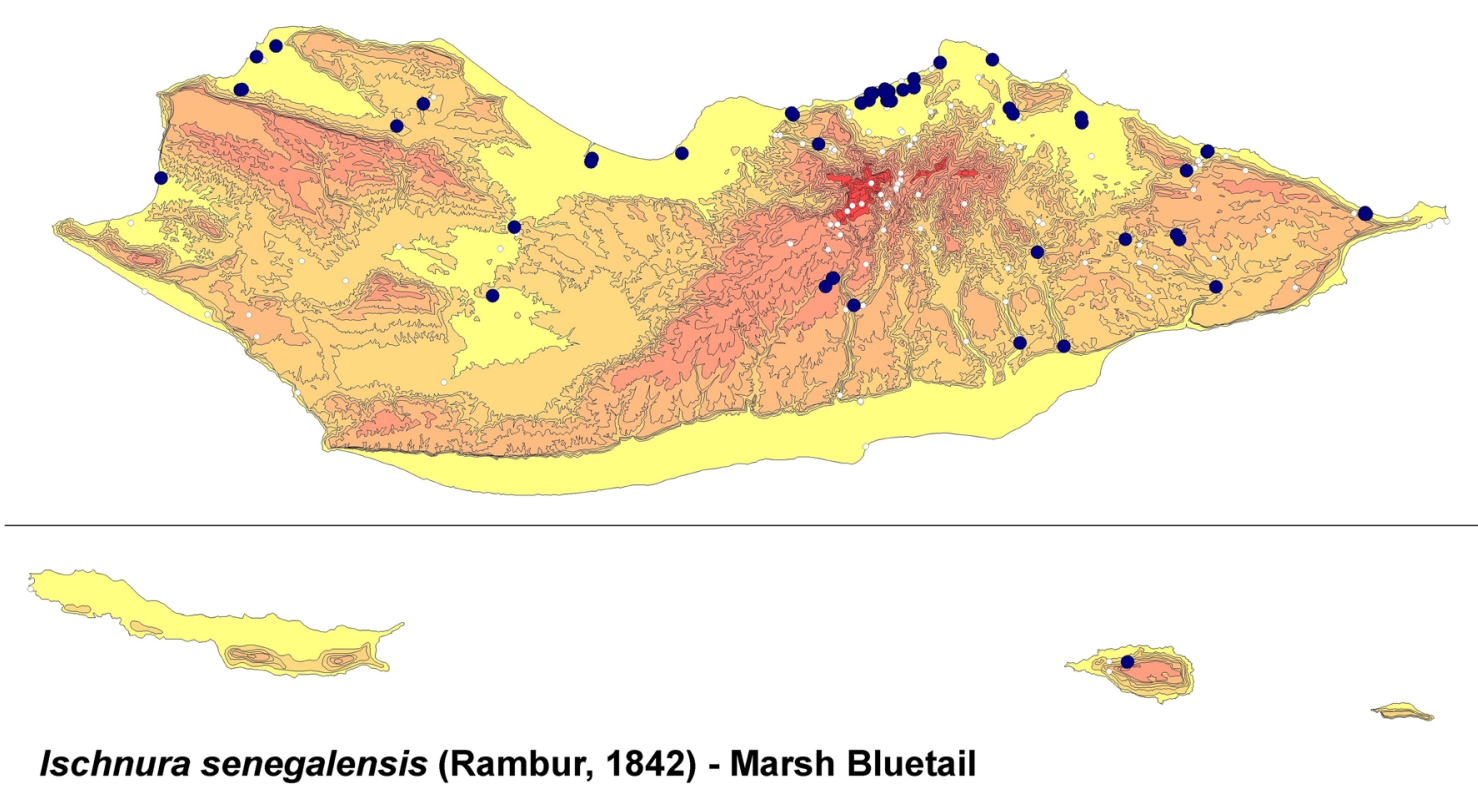

Fig. 8 Distribution of Ischnura senegalensis in the Socotra Archipelago (Yemen)

Oman, $C$. glabrum is known to need sufficient vegetation on the banks for oviposition (Lambret et al. 2017). On Socotra such low grassy vegetation is common in localities where $C$. glabrum is found. The reddish-orange colour (Fig. 2e) provides effective camouflage against dry vegetation (Wranik 2003). Only two records in western Socotra so far exist, one in the central Zahr Plain and one westernmost record at the sheltered wetland Qaysoh near Qalansiyah (Fig. 7). The species is widespread in Africa south of the Sahara, Madagascar, the southern half of the Arabian Peninsula and occurs in several Indian Ocean Islands (Boudot et al. 2016a; Lambret et al. 2017); it is regionally extinct in northern Africa where it was known from Egypt (Samraoui et al. 2010).

\section{Ischnura senegalensis (Rambur, 1842)-Marsh Bluetail}

(Fig. 2f habitus; Fig. 8 map)

Tolerant to a wide range of salinities and occurring in different habitats, widely distributed and relatively common on Socotra Island, in total adding up to $8 \%$ of all records (Fig. 8). Ischnura senegalenis (Fig. 2f) is the only damselfly occurring on any of the outer islands in the archipelago (Samha Island; Wranik 2003). It is a typical and locally abundant species of stream banks, marshes, wetlands and brackish lagoons. It is one of the few species on Socotra that reproduces in brackish environments (ovipositing females observed in this study) where it is often joined by Macrodiplax cora. Found in coastal lagoons and wadis along the northern coast including Hadiboh, Sirihin Lagoons in the east and Qalansiyah Lagoon in the west and as well as inland wadis such as Wadi Ziyreg. Common in the Hadiboh Plain, up to $600 \mathrm{~m}$ elevation, but most common at 0-300 m. Can be abundant in localities with hypersaline conditions such as a brine collection site along the north coast, the Ghubbah sinkhole. The Marsh Bluetail is among the most wide-ranging dragonflies in the world. It can be found in the Old World, with a large distribution in Africa and Asia (Boudot 2015).

\section{Anisoptera-Dragonflies \\ Aeschnidae-Hawkers}

\section{Anax imperator (Leach, 1815)_Blue Emperor}

(Fig. 9a habitus; Fig. 10 map)

Widespread in Socotra Island at altitudes of 0-1200 m, yet not the most common species (5\% of the records; Fig. 10). Not in the outer islands. Known from Socotra since McLachlan (1903), as Anax mauricianus Rambur, 1842. Present in brackish environments such as Sirihin and Qalansiyah Lagoon, and in freshwater streams on the eastern plateaus. Found at Diksam and Momi and wadis coming down from the mountains such as 'Ayhaft and Dineghan. Breeding observed in both freshwater and brackish localities such as Sirihin Lagoon (Fig. 9a). Often hovering above larger stretches of water in wadis. Present in western and eastern localities on Socotra Island, yet only a few records in the west (Fig. 10). The species is widespread across western Asia, Africa and Europe (Dumont 1991; Kalkman and Proess 2015). 


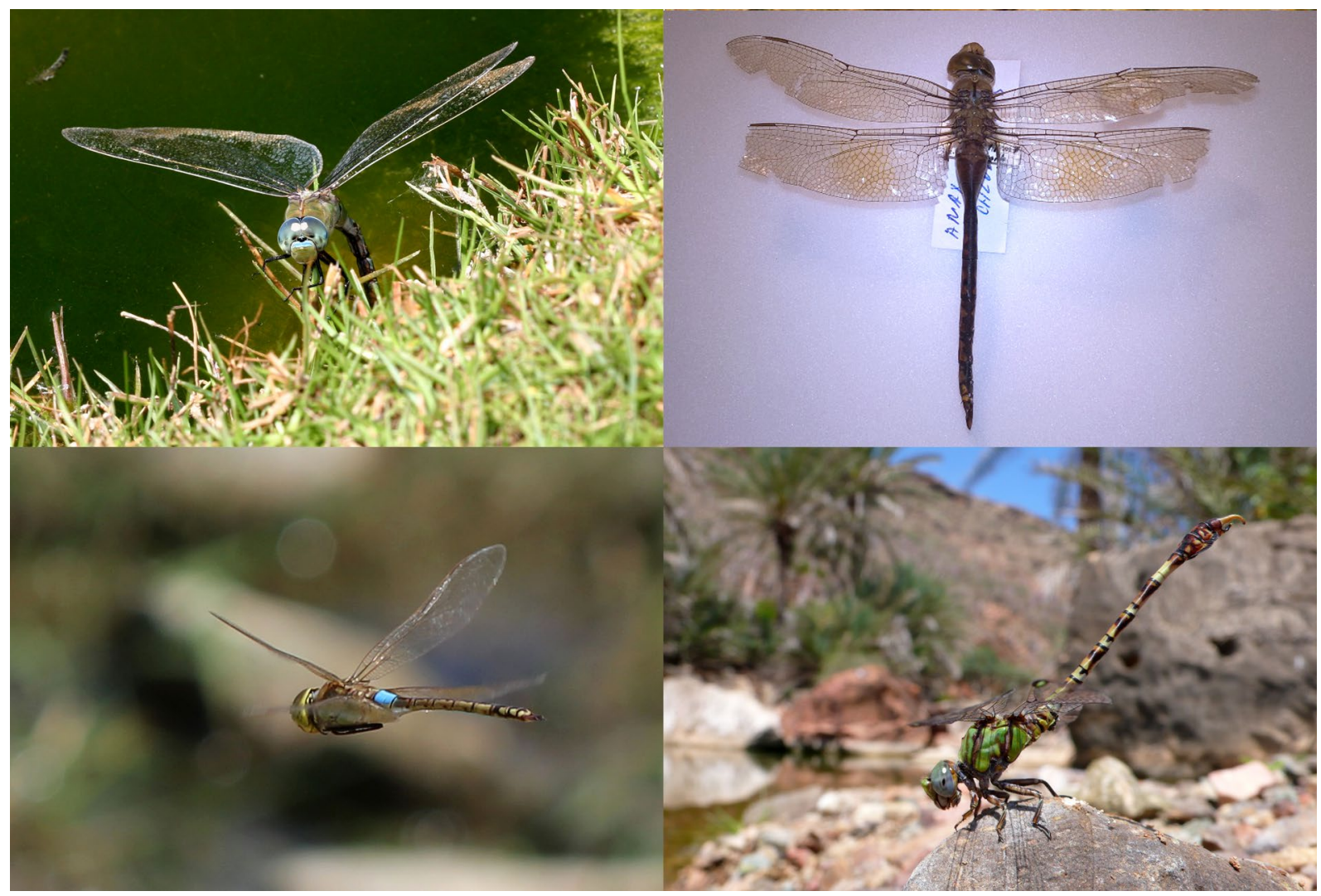

Fig. 9 Aeschnidae and Gomphidae (Anisoptera) from the Socotra Archipelago (Yemen). a Anax imperator ovipositing female; b Anax indicus? (A. guttatus-group) male; c Hemianax ephippiger male; d Paragomphus genei male. a photo R. Ketelaar, Di-Hashus, Socotra
Island, 26-02-2009, b photo P. Jeziorski, National Museum of Prague, coll. W. Wranik, c photo R. Ketelaar, Wadi Ziyreg, Socotra Island, 06-11-2010, d photo R. Ketelaar, Qaryiah Lagoon, Socotra Island, 24-02-2009

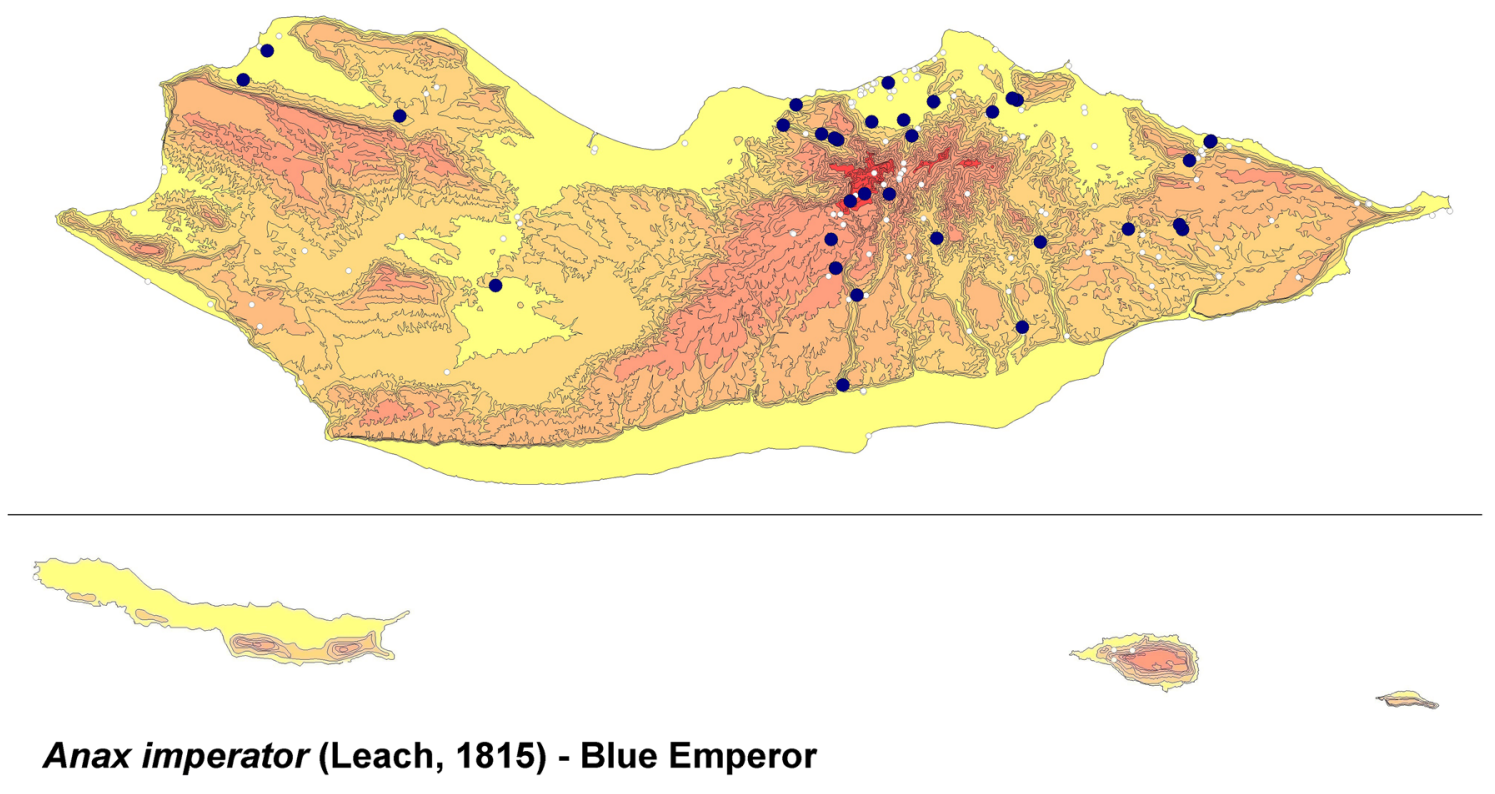

Fig. 10 Distribution of Anax imperator in the Socotra Archipelago (Yemen) 


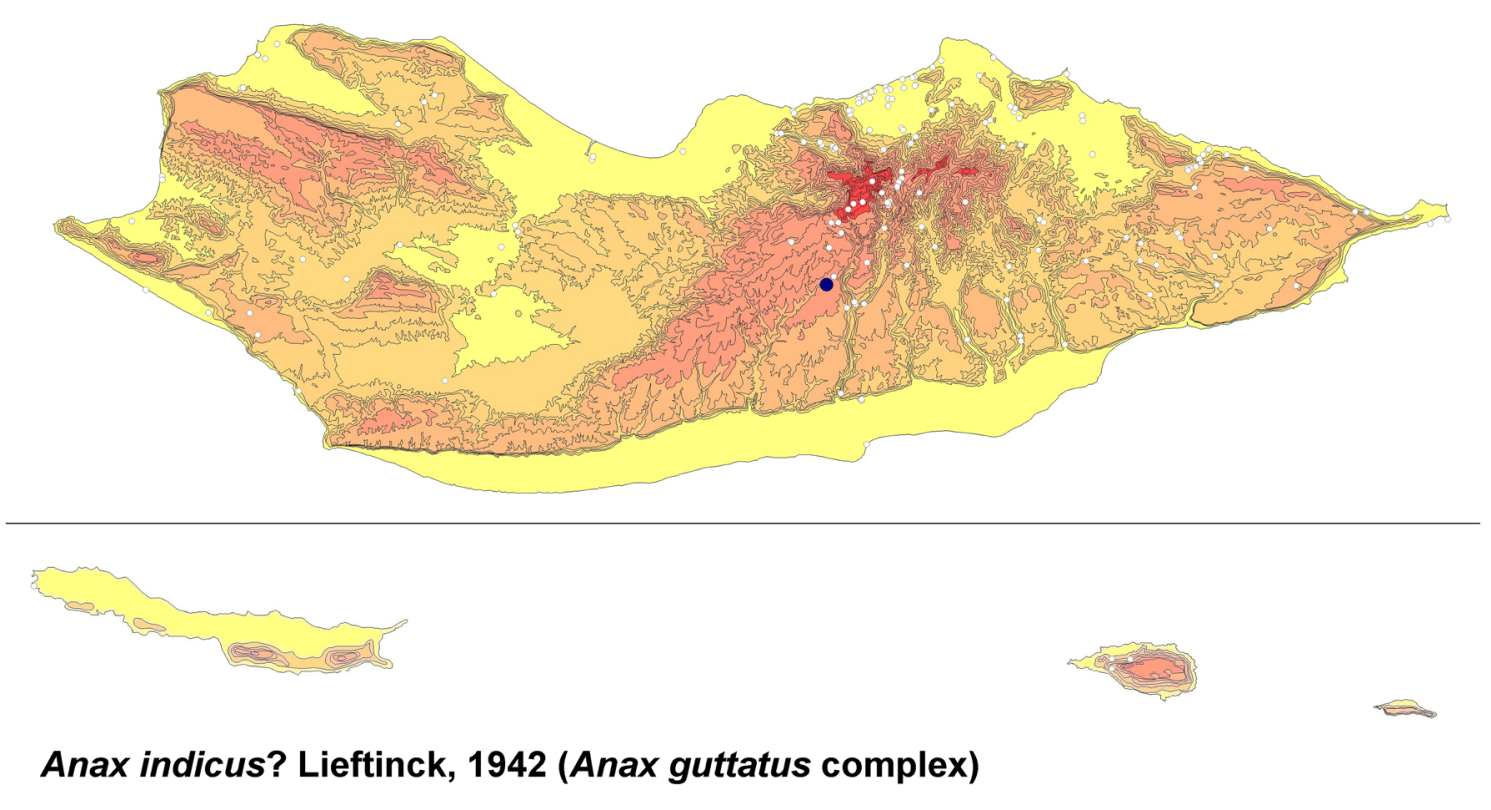

Fig. 11 Distribution of Anax indicus? (A. guttatus complex) in the Socotra Archipelago (Yemen)

7. Anax guttatus (Burmeister, 1839) species complexLesser Green Emperor (Anax indicus? Lieftinck, 1942)

(Fig. 9b habitus; Fig. 11 map)

A single adult female specimen from the W. Wranik collection in Prague Museum (Fig. 9b), collected from the Diksam plateau at $600-900 \mathrm{~m}$ alt (Fig. 11) on Socotra Island in 1997 was identified by Petr Jeziorski as A. indicus?
Lieftinck, 1942 (Jeziorski unpubl. data). The locality is described by W. Wranik (pers. comm. 2020) as a part of Wadi Ziyreg, "a small running water area with some deeper and more stagnant water areas among the larger boulders and green around-later this area was affected by road building". In flight, this animal could be confused with another aeschnid on Socotra, Hemianax ephippiger (Fig. 9c), as the abdominal second segment of both species has a blue dorsum; however, wing venation differs

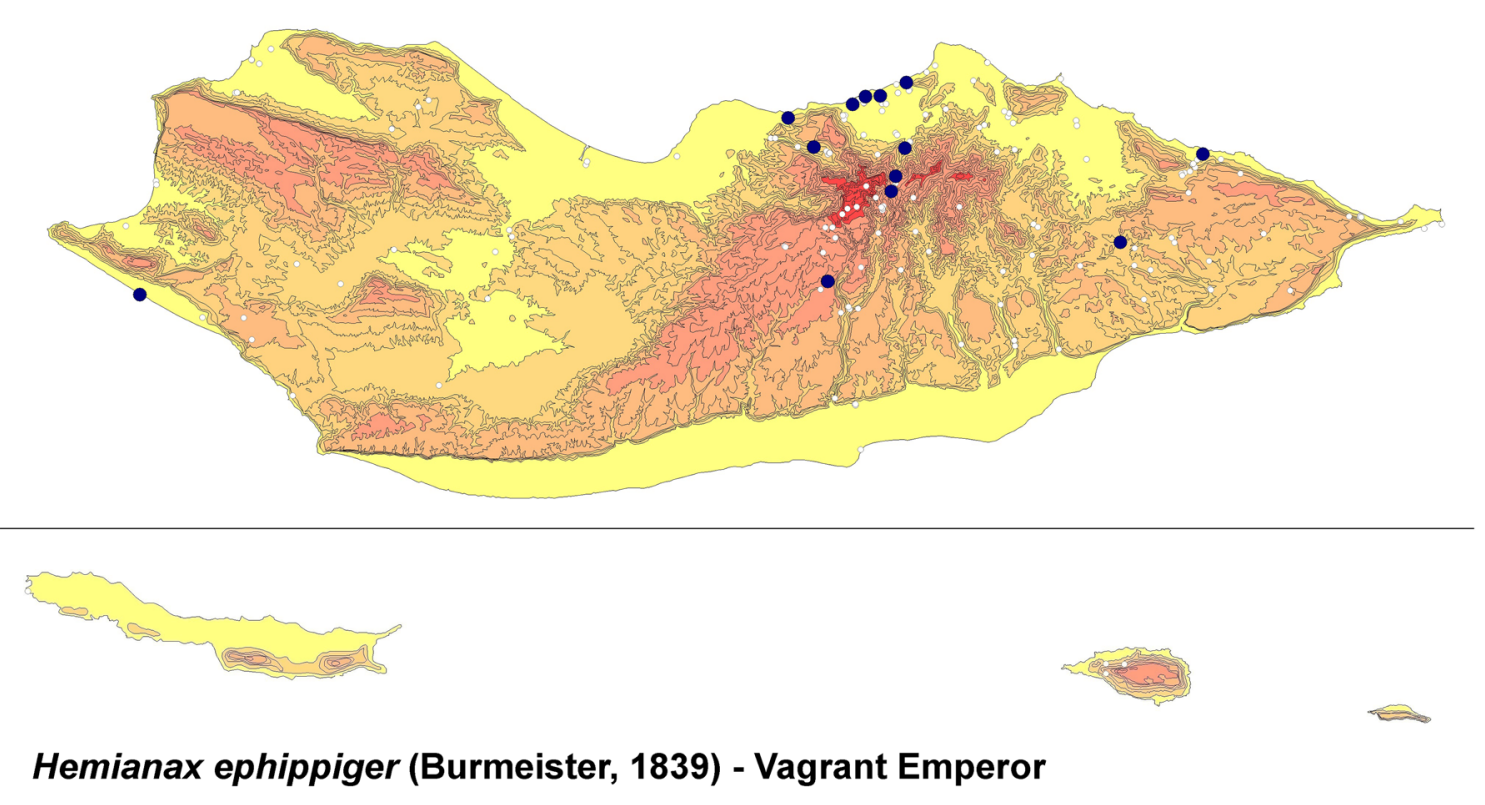

Fig. 12 Distribution of Hemianax ephippiger in the Socotra Archipelago (Yemen) 
between the latter and the Oriental taxon (see Dumont 1991 and Wranik 2003 for wing venation of H. ephippiger). The specimen at Prague Museum (Fig. 9b) can be clearly identified as an Anax, not a Hemianax. Anax indicus is a species that forms part of an Oriental A. guttatus-complex with wide distribution in need of revision. Members of this group occur in SE Asia and India, yet can be found in remote islands, including the Seychelles (Belyshev and Haritonov 1978; Samways 2003a). The single record should be treated with care until the presence of a third member of Aeschnidae on Socotra can be confirmed. In future surveys, potential populations of $H$. ephippiger on the island should be checked closely to establish whether superficially similar species are present, such as this unusual record. It is likely, however, that this record concerns an occurrence of migration and that no permanent population is established.

\section{Hemianax ephippiger (Burmeister, 1839)_-Vagrant Emperor}

(Fig. 9c habitus; Fig. 12 map)

Rarely seen in Socotra (2\% of the records; Fig. 12), present in diverse habitats, both in brackish and freshwater sites at altitudes 0-900 m. Not in the outer islands. First record in 1898 from the Hadiboh Plain (McLachlan 1903), where it still occurs; the last observation in the brackish Sirihin Lagoon is from 2010 where the species breeds (ovipositing female observed in this study). Found in the Hadiboh Plain in lagoons and wadis, in freshwater in Wadi 'Ayhaft and scattered localities along the northern coast, in Momi and in Diksam, mostly in flight. Not observed from the western half of Socotra, except for one record from the mangrove areas at Neet (Fig. 12). This species is a strong flyer (Fig. 9C) and has a wide distribution in Africa, Western Asia and occurs up to the northern parts of Europe as a vagrant (Lambret and Boudot 2013; Kalkman and Monnerat 2015a). See also the A. guttatus group above (Fig. 9b) for notes on a similar member of the Aeschnidae with a blue "saddle" that may be present in Socotra.

\section{Gomphidae - Clubtails}

\section{Paragomphus genei (Selys, 1841) — Green Clubtail}

(Fig. 9d habitus; Fig. 13 map)

Widespread, yet not a common species in Socotra Island (3\% of the records) occurring from sea level to $1200 \mathrm{~m}$ elevation in the Hageher mountains (Fig. 13). Not in the outer islands. In a wide range of habitats, mainly standing freshwater; also recorded from the brackish Qariyah Lagoon on the northwestern coast. In flowing waters and pools in the mountains and on the plateaus, present in east and west of Socotra Island: however there are only two western records, of which one in the Zahr Plain. Common in Wadi 'Ayhaft and Dineghan. An obvious species, often perching on boulders or on smaller rocks or bare soils along wadis (Fig. 9d) and foraging far from the waters in the valleys. The species is typically African and Mediterranean; it occurs widely in the western Mediterranean and has a disjunct distribution in the
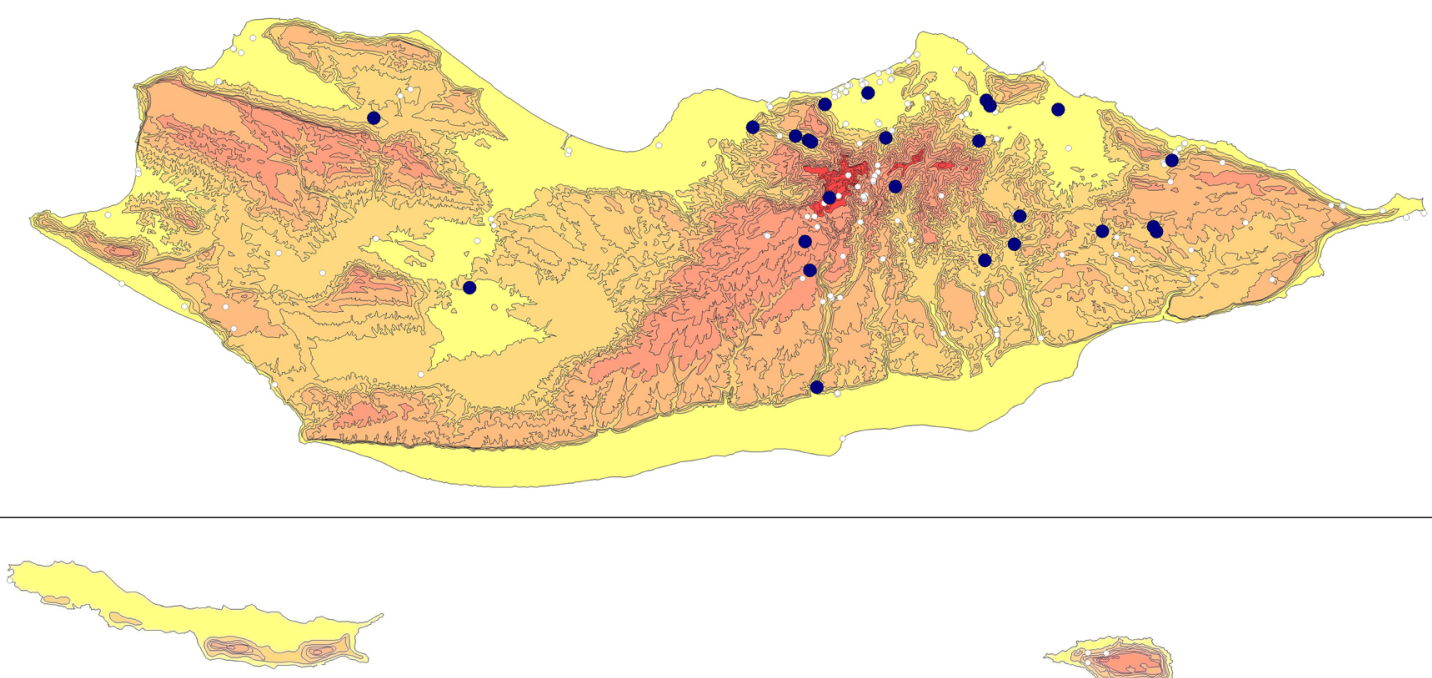

Paragomphus genei (Selys, 1841) - Green Clubtail

Fig. 13 Distribution of Paragomphus genei in the Socotra Archipelago (Yemen) 

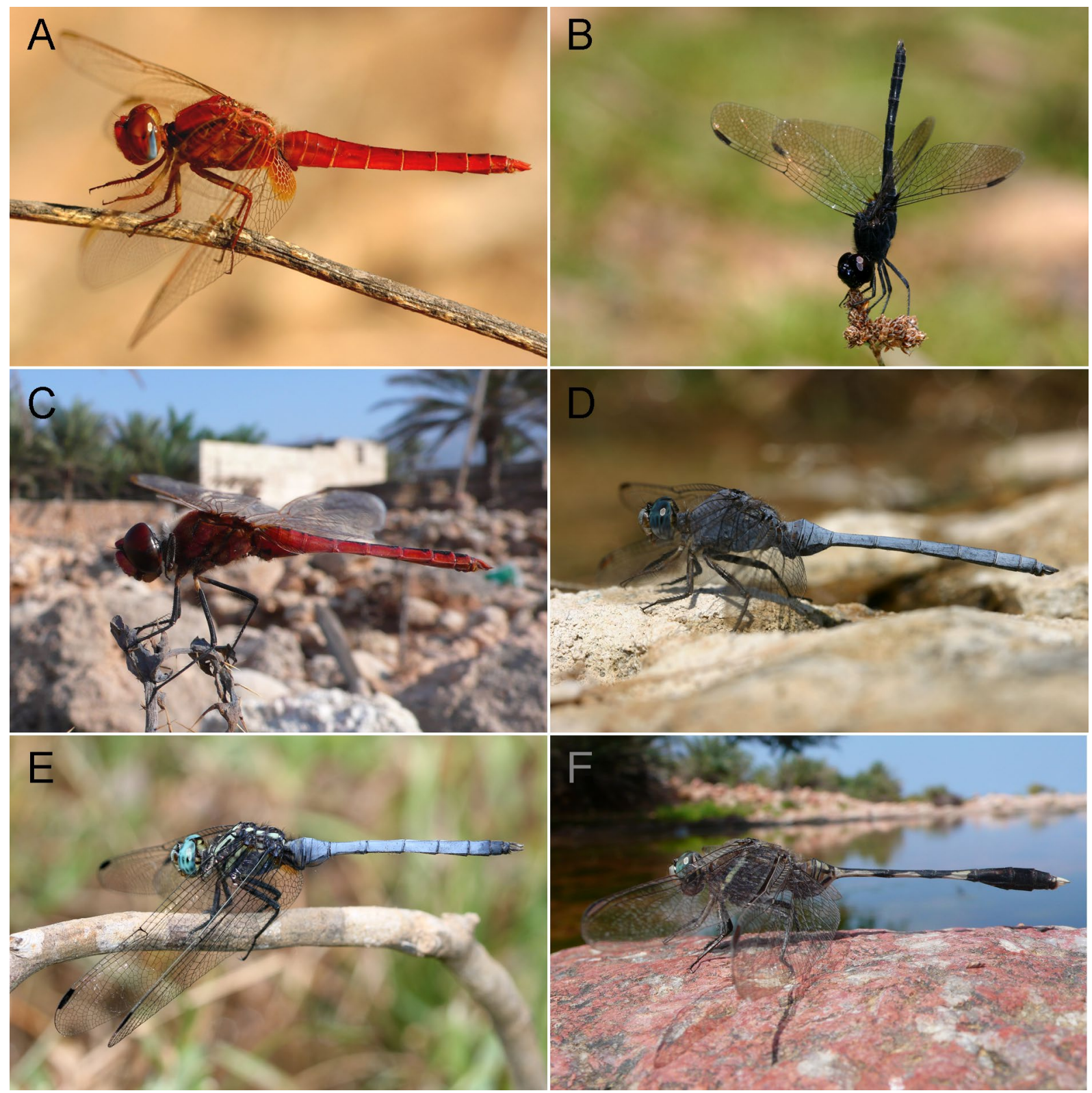

Fig. 14 Libellulidae (Anisoptera) from the Socotra Archipelago (Yemen). a Crocothemis erythraea male; b Diplacodes lefebvrii male; c. Macrodiplax cora male; $\mathbf{d}$ Orthetrum chrysostigma male; e Orthetrum julia falsum male; f Orthetrum sabina male. a photo R. Ketelaar, Wadi Irih, Socotra Island, 03-03-2009, b photo R. Kete-

Middle East (Boudot et al. 2016b). Socotra is one of the few easternmost disjunct localities in its range.

\section{Libellulidae-skimmers}

\section{Crocothemis erythraea (Brullé, 1832)—Broad Scarlet}

(Fig. 14a habitus; Fig. 15 map)

laar, Ridah, Momi, Socotra Island, 24-02-2009, c photo R. Ketelaar, Qhadub Lagoon, Socotra Island, 24-02-2009, d photo R. Ketelaar, Wadi Ziyreg, Socotra Island, 21-02-2009, e photo R. Ketelaar, 'Adho di-Meleh, Socotra Island, 05-11-2010, f photo R. Ketelaar, Wadi Dineghan, Socotra Island, 20-02-2009

One of the most common dragonfly species on Socotra (10\% of the records) with broad ecology and tolerance, occurring at $0-1100 \mathrm{~m}$ altitude in a wide range of aquatic habitats (Fig. 15). One record is known from Samha island (Riservato et al. 2010). The Broad Scarlet is abundant in coastal brackish habitats such as Qariyah and Sirihin Lagoons on the north coast of Socotra, in wadi pools and along streams, like Wadi 'Ayhaft, Dineghan, Ziyreg and the small spring at 'Arher. Also found in hypersaline conditions in brine collection pans 


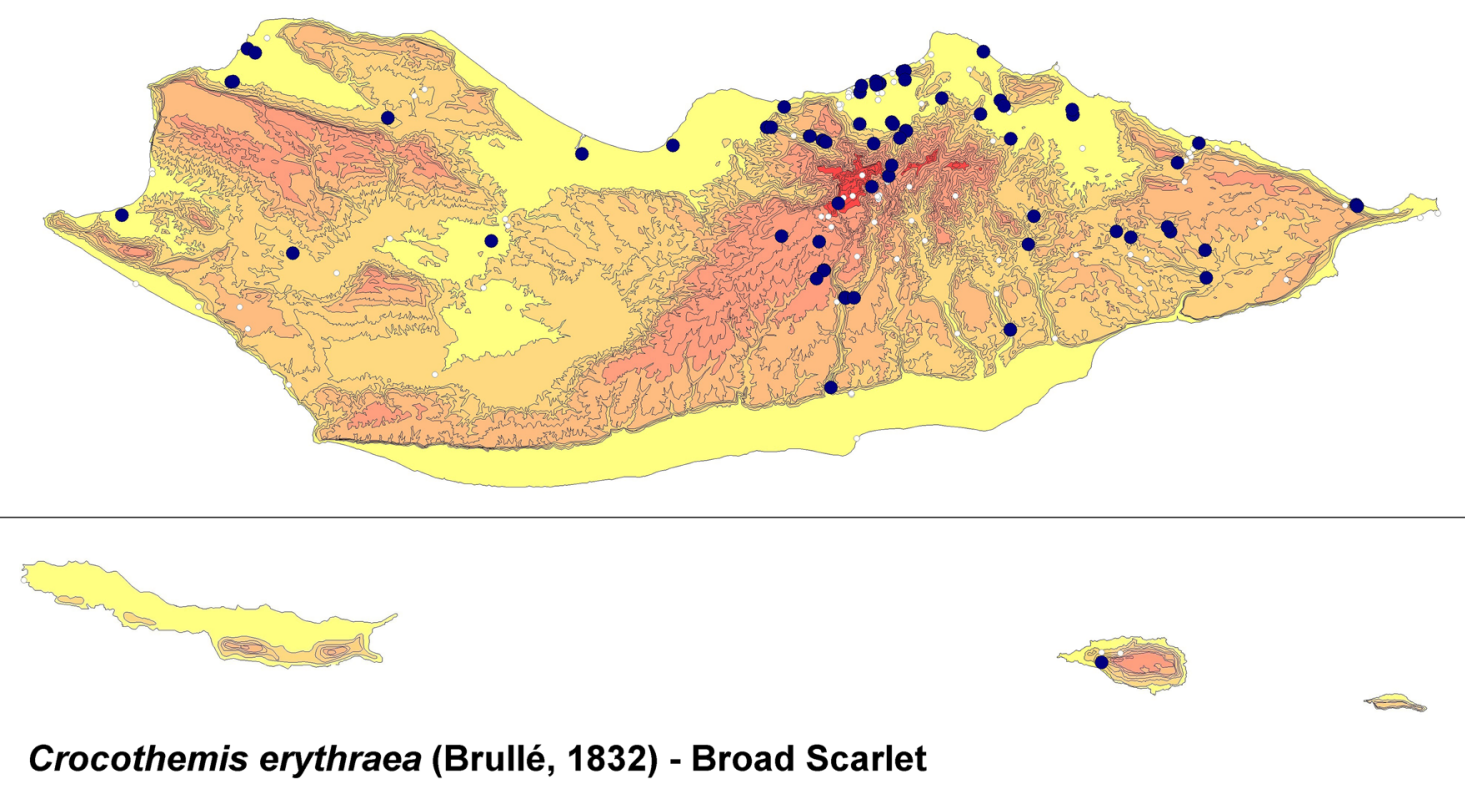

Fig. 15 Distribution of Crocothemis erythraea in the Socotra Archipelago (Yemen)

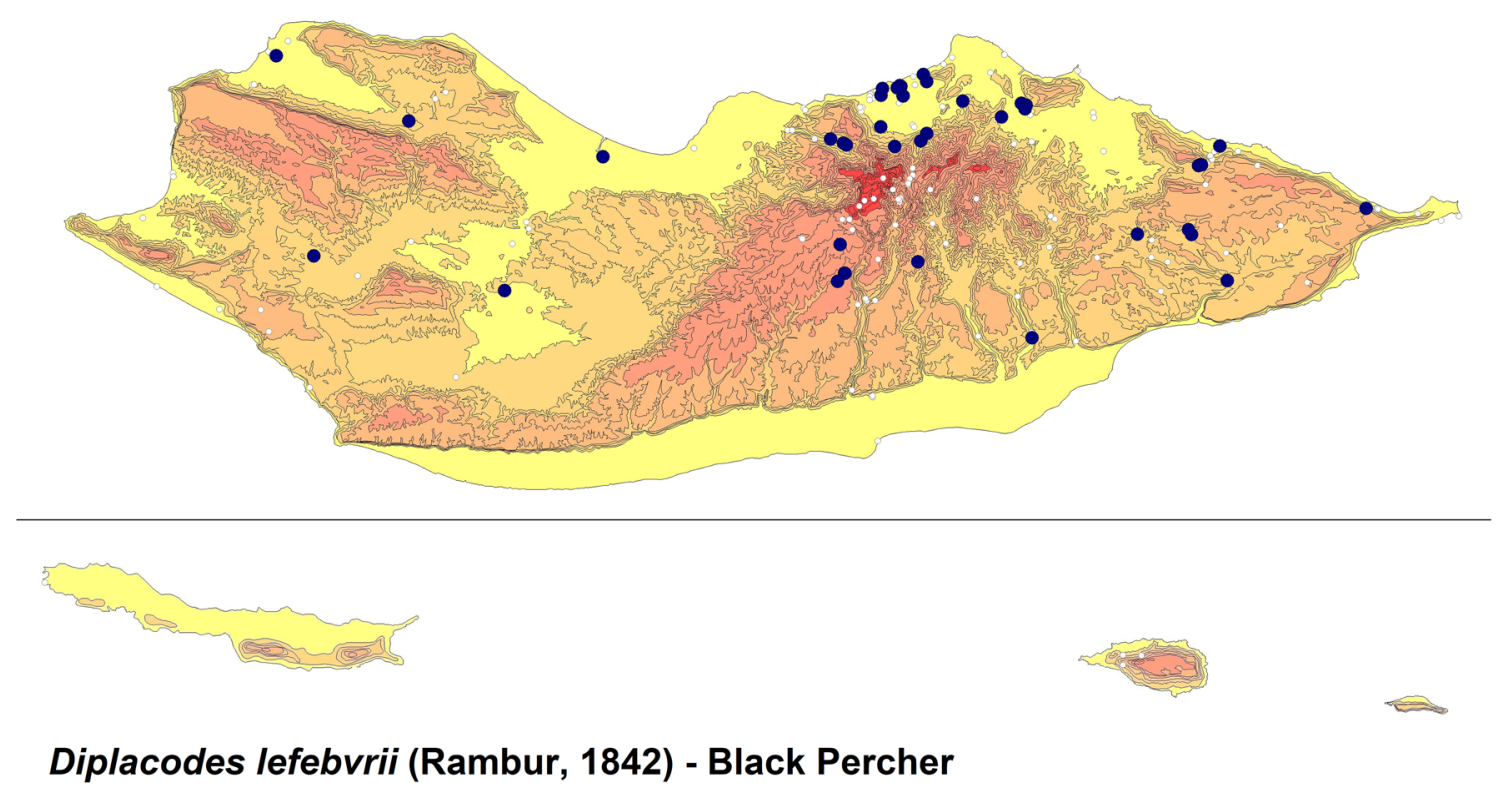

Fig. 16 Distribution of Diplacodes lefebvrii in the Socotra Archipelago (Yemen)

in a sinkhole at Ghubbah. Common around artificial wells and water reservoirs. Present in the Hadiboh Plain since the earliest records (McLachlan et al. 1898). The species occurs in northern Europe and Africa to West Asia, and is common on the Arabian mainland (Clausnitzer 2016a). We identified the Broad Scarlet from a photo taken on a large naval ship on patrol in the Indian Ocean near Socotra, illustrating the migratory capacity and likely recurrent colonisation of this species (BBC News 2013).

\section{Diplacodes lefebvrii (Rambur, 1842)—Black Percher}

(Fig. 14b habitus; Fig. 16 map)

Widespread in east and west Socotra and mainly present in lowland areas along the northern coast and on plateaus such as Momi and Diksam from sea level to $800 \mathrm{~m}$ altitude (Fig. 16). Not the most common dragonfly in Socotra (6\% of all records), yet locally abundant. Typical for more open 


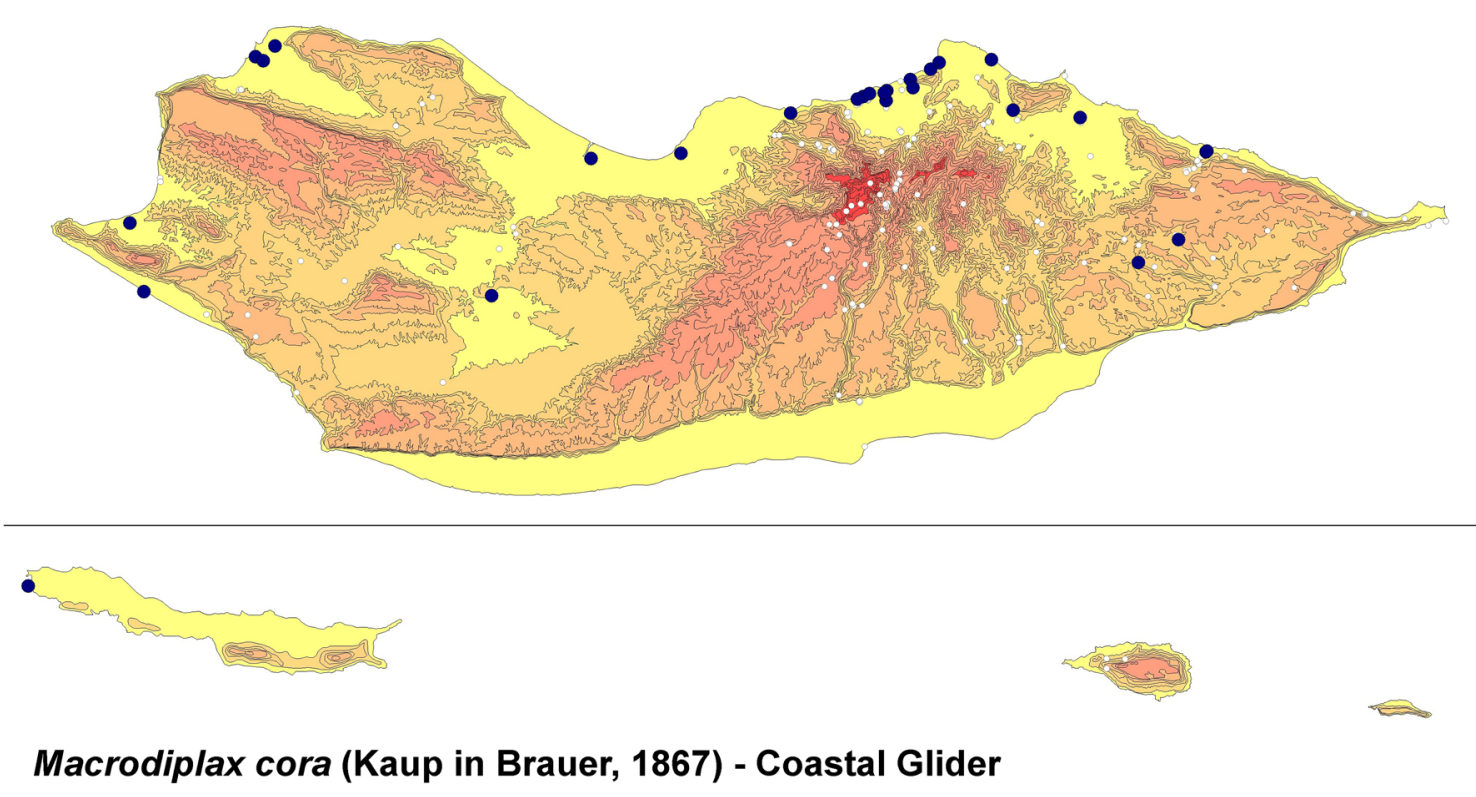

Fig. 17 Distribution of Macrodiplax cora in the Socotra Archipelago (Yemen)

lowland, not found in the high central Hageher mountain areas. Present in a wide range of habitats in both east and west Socotra, including lagoons in urban areas such as near Hadiboh and Qalansiyah. Also in slow running waters and pools such as in Wadi 'Ayhaft and Kilisan. Present at hypersaline conditions in the brine collection site at Ghubbah on the north coast, yet breeding probably only in freshwater. Commonly seen perching (Fig. 14b) in the city of Hadiboh on walls and fences. The Black Percher is widespread in Africa and ranges to southern Europe in the north and India in the east; in the Arabian Peninsula, the distribution is disjunct (Kalkman and De Knijf 2015; Dow and Clausnitzer 2016).

\section{Macrodiplax cora (Kaup in Brauer, 1867)_Coastal Glider}

(Fig. 14c habitus; Fig. 17 map)

A species tolerant of higher salinities. On Socotra, the Coastal Glider is not common ( $4 \%$ of all records), yet locally abundant and mainly restricted to its typical habitat, lagoons and estuarine waters where it breeds (Fig. 17). Mostly found between 0 and $50 \mathrm{~m}$ altitude, sporadically higher (200-300 m on Momi Plateau). It is the only dragonfly species recorded from brackish waters in Abd al Kuri, the westernmost island

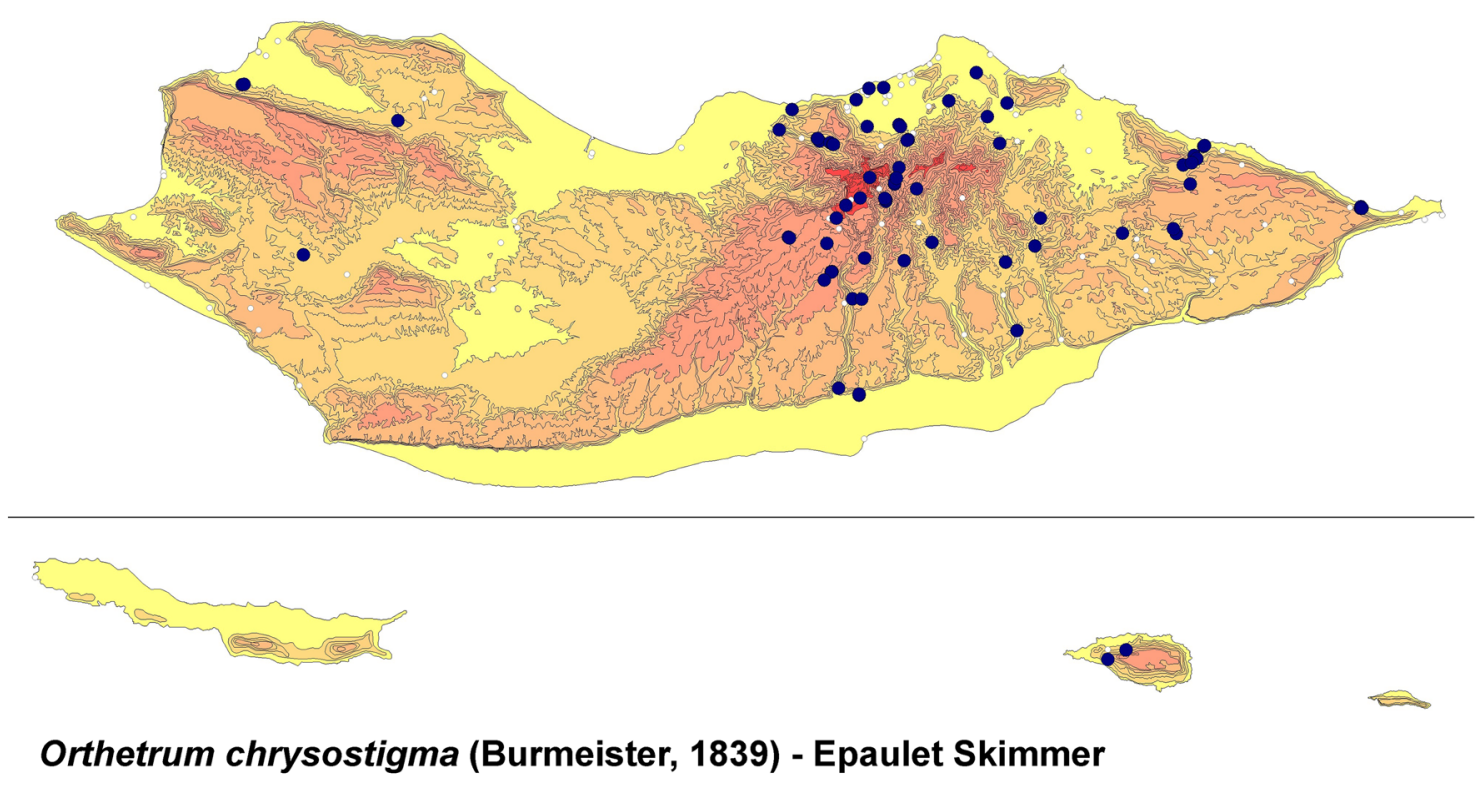

Fig. 18 Distribution of Orthetrum chrysostigma in the Socotra Archipelago (Yemen) 
in the archipelago (Riservato et al. 2010; Fig. 17). Macrodiplax cora is locally abundant in brackish waters and estuaries near the main cities Hadiboh and Qalansiyah and is often seen in these urban areas (Fig. 14c). A few inland records in Socotra include freshwater habitats on the eastern plateau (Momi) and in the central lowlands (Zahr plain). Not recorded from the southern coast of Socotra so far. The Coastal Glider is a widespread migrant with its main distribution in tropical Asia and Australasia extending to western Indian Ocean islands, Oman, southern Yemen and few locations in Africa such as Somalia and the the northeastern tip of South Africa in Kwazulu Natal (Sharma 2013; Dijkstra and Clausnitzer 2014; Lambret et al. 2017). Socotra is one of the few areas in the western limits of its range. The species can be seen as a local indicator of brackish waters, which are under pressure because of coastal developments.

\section{Orthetrum chrysostigma (Burmeister, 1839)_Epaulet Skimmer}

(Fig. 14d habitus; Fig. 18 map)

One of the most common species in Socotra, about $10 \%$ of all records in our database. In a wide range of habitats in the lowlands, on the plateaus and in the high mountain areas between sea level and $1200 \mathrm{~m}$ (Fig. 18). It is abundant along Socotra's coastal lagoons, man-made wells, pools and pristine freshwater streams, most typical for stagnant and slow-flowing waters in quite open areas. It occurs in wadis with vegetated as well as unvegetated banks. One of the few dragonfly species that also occur in Samha Island (Fig. 18), in man-made wells with nearly no surrounding vegetation. Typically seen perching on boulders along the wadis on Socotra, such as in Wadi 'Ayhaft and Wadi Dineghan and around reservoirs (Fig. 14d). Very similar to the Julia Skimmer in Socotra, and close investigation is needed to distinguish both. The Epaulet Skimmer reaches the Canary islands in the west and occurs throughout Africa, southern Europe and parts of the Arabian Peninsula (Kalkman and Monnerat 2015b).

\section{Orthetrum julia Kirby, 1900 ssp. falsum Longfield, 1955-Julia Skimmer}

(Fig. 14e habitus; Fig. 19 map)

A very rare species on Socotra, absent from the outer islands (Fig. 19). First recorded by Schneider and Nasher (2013) from a specimen collected by H. Pohl in 1999. We counted four records in total, from relatively undisturbed (but grazed) permanent freshwater environments in sheltered areas in Socotra Island. Three sightings are from 600-900 m altitude in the Hageher mountains in the upper course of Wadi Dineghan and its sources at the "Adho di-Meleh pass (Fig. 19); one specimen in the collection at Prague Museum originates from the sheltered entrance of Dejub cave in the southern Noged plain, at around $100 \mathrm{~m}$ altitude. The large entrance of the cave contains small permanent pools at the entrance which are fed by drips from the karstic limestone. Except for the one southern record, all records known from Socotra are in a mountain area of less than one $\mathrm{km}^{2}$. We also recorded a larva of $O$. julia falsum in 2010 from a
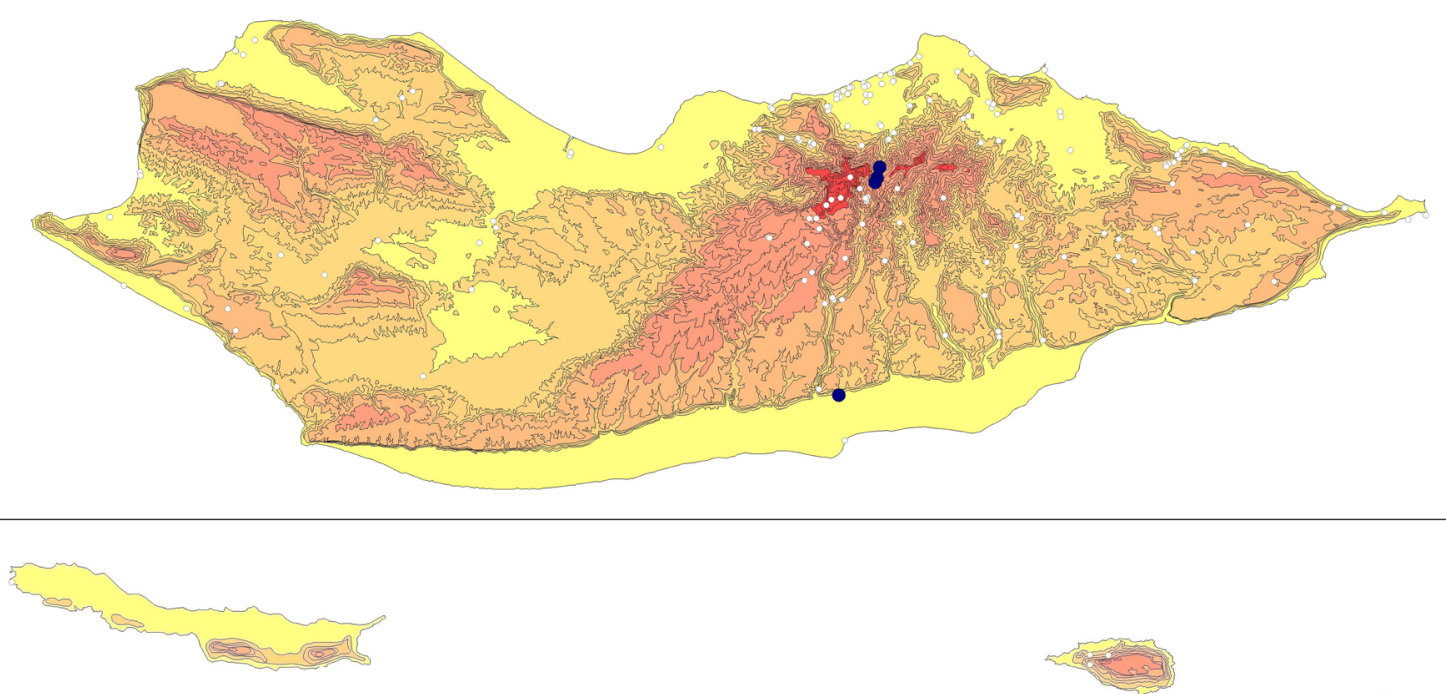

Orthetrum julia Kirby, 1900 ssp. falsum Longfield, 1955 - Julia Skimmer

Fig. 19 Distribution of Orthetrum julia falsum in the Socotra Archipelago (Yemen) 


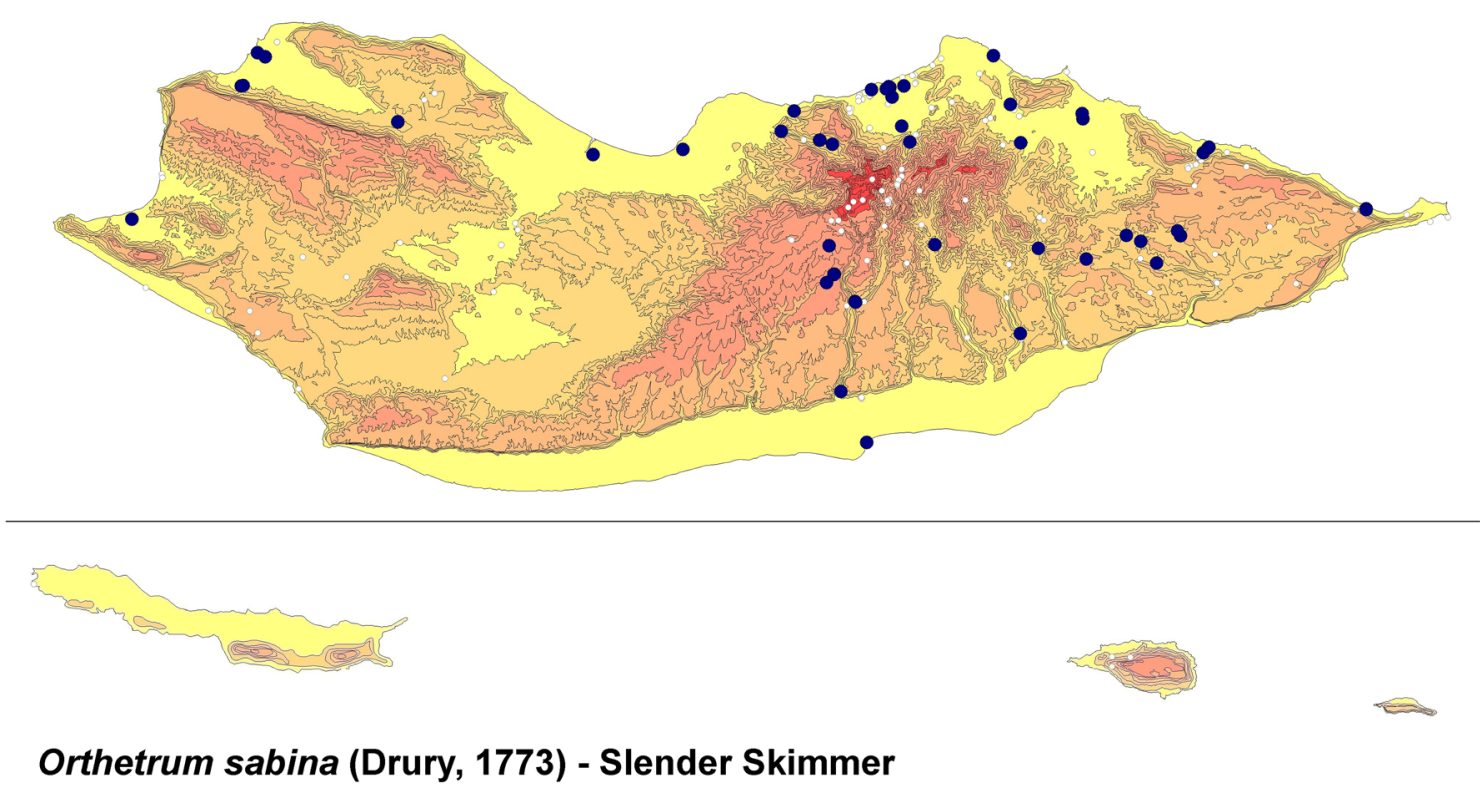

Fig. 20 Distribution of Orthetrum sabina in the Socotra Archipelago (Yemen)

small, shallow and grassy stream at the 'Adho di-Meleh pass together with ten males and three females (Fig. 14e); this is the only locality where several individuals were found and reproduction is confirmed. In the field, $O$. julia falsum and $O$. chrysostigma are nearly identical and these two species can only be distinguished by close examination (Figs. 14d, e). Although $O$. julia falsum seems to be mainly restricted on the main island to the high mountain areas near "Adho di-Meleh, it is likely that its distribution in perennial sheltered streams on Socotra Island may be wider than currently assumed, due to confusion with $O$. chrysostigma. The subspecies is widespread in Africa and southwestern parts of the Arabian Peninsula (Schneider and Parr 1998).

\section{Orthetrum sabina (Drury, 1773)—Slender Skimmer}

(Fig. 14f habitus; Fig. 20 map)

Relatively common on Socotra (7\% of the records) and with a wide ecological range, mostly present in permanent waters (Fig. 20). The oldest record is from 1953 in Hadiboh (Kimmins 1960), where the species still occurs. O. sabina is common in urban areas in Hadiboh and Qalansiyah in disturbed coastal wadis and lagoons, but equally present in pristine freshwater areas on the plateaus and the mountains, at altitudes of 0-800 m (Fig. 14f). Found in western and eastern Socotra, relatively less common than $O$. chrysostigma. The Slender Skimmer occurs in parts of northern Africa and throughout the Arabian Peninsula, Asia and Australia (Kalkman 2015).

\section{Pantala flavescens (Fabricius, 1798)—Globe Skimmer}

(Fig. 21a habitus; Fig. 22 map)

Widespread and one of the most common dragonflies in Socotra Island at $0-1100 \mathrm{~m}$ altitude and present at sea level in Samha Island (Fig. 22). Constitutes 9\% of all records. One of the most locally abundant species in Socotra, especially at stagnant pools and slow flowing wadis, sometimes forming swarms. Known from the Hadiboh Plain since the earliest records (MacLachlan et al. 1896) from Tamarida, an old name for Hadiboh, where the species is still common. Found in a wide range of habitats, in mangrove stands in Neet, coastal lagoons in Hadiboh and Qalansiyah, and wadi pools and streams such as 'Ayhaft and Ziyreg. May appear in large swarms on Socotra Island in October-November (Porter 2011). The Globe skimmer is often seen in flight (Fig. 21a); it is a highly migratory widespread species that can be found in large parts of both the Old and the New World (Dumont 1991; Kalkman and Monnerat 2015).

\section{Rhyothemis semihyalina Desjardins, 1832 ssp. separata (Selys, 1849)_Phantom Flutterer}

(Fig. 21b, c habitus; Fig. 23 map)

Not found in Socotra since 1953. We consider that this species (Figs. 21b, c) may be locally extinct (Riservato et al. 2010; Van Damme and Banfield 2011). Five records are known, dating from 1896 to 1953 (Fig. 23). Near the end of 


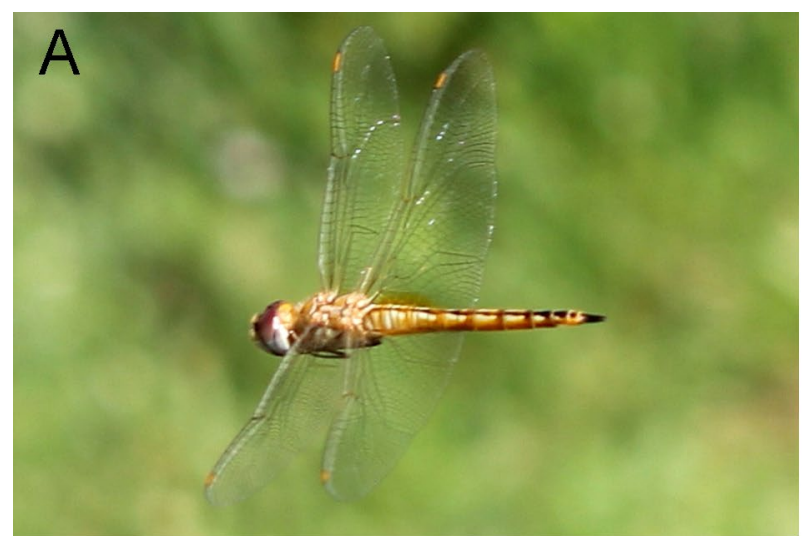

B
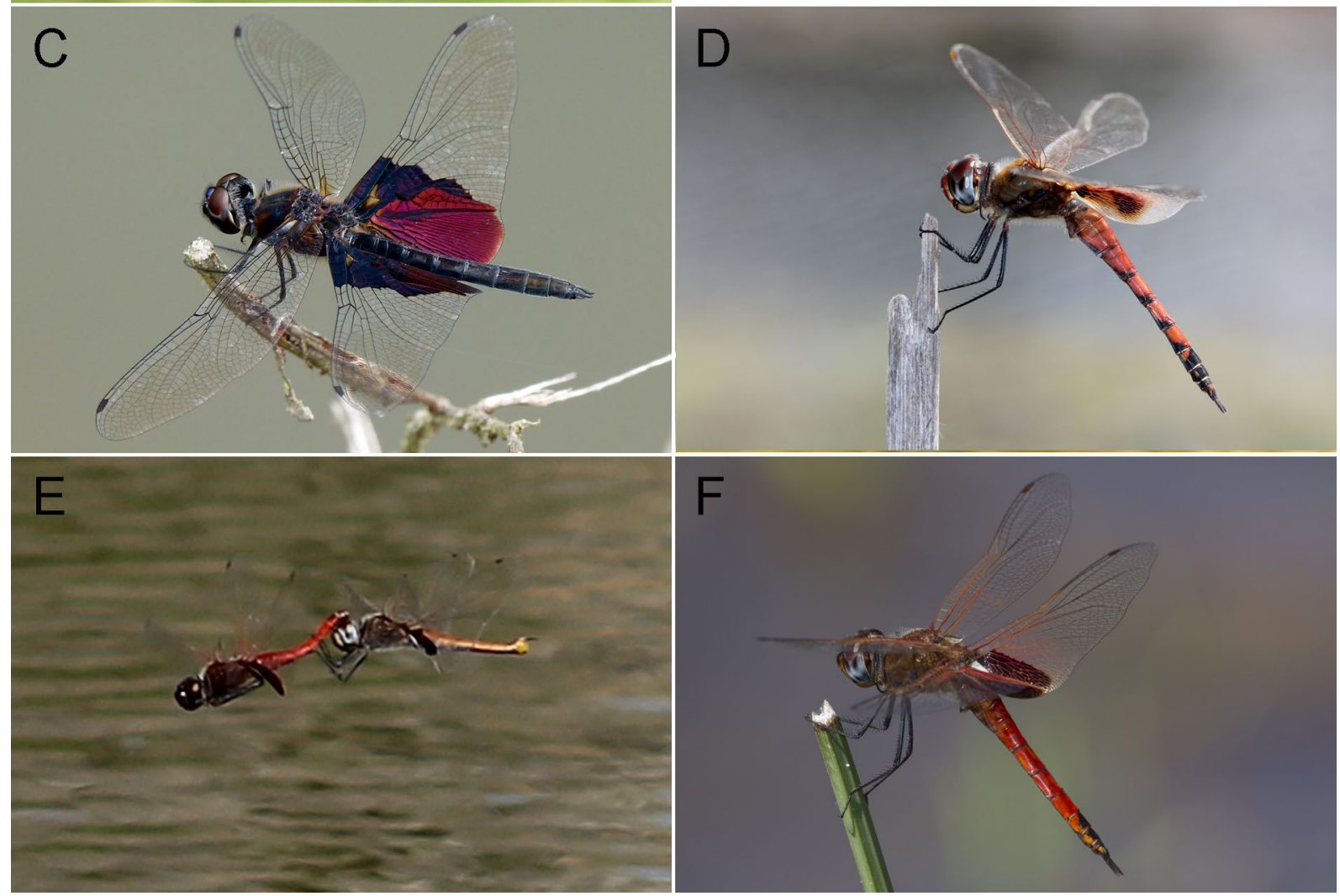

Fig. 21 Libellulidae (Anisoptera) from the Socotra Archipelago (Yemen). a Pantala flavescens male. b Rhyothemis semihyalina (locally extinct) from Hadiboh lagoons in 1898, after McLachlan (1903); c Rhyothemis semihyalina, male (not from Socotra); d Tramea basilaris male; e Tramea limbata tandem; F. Tramea limbata male (not from Socotra). a photo R. Ketelaar, 'Arher, Socotra Island,

04-11-2010, c photo M. Eising, Andasibe-Mantadia National Park, Madagascar, 12-01-2014, d photo R. Ketelaar, Khor Sirhin, Socotra Island, 07-11-2010, e photo R. Ketelaar, Wadi Ziyreg, Socotra Island, 06-11-2010, f photo J. Wilkinson, Tshipise, Limpopo, South Africa, 29-03-2018

the nineteenth century, the Phantom Flutterer was present at the outskirts of Socotra's two main cities, which strongly expanded since, Hadiboh and Qalansiyah. Ernest N. Bennett, in MacLachlan et al. (1898), mentioned R. semihyalina as "common near the lagoons of Ghalansiya" in the west and W.R. Ogilvie-Grant (MacLachlan 1903) collected four males in the Hadiboh Plain in 1898 (Fig. 21b). Later, Kimmins (1960) reported $R$. semihyalina from at least three separate localities visited by Popov in the latter area. All records are

from localities at sea level along the coast, and the species may have been common in the coastal areas. Rhyothemis semihyalina is a conspicuous species (Fig. 21c) with a butterfly-like flight that occurred in the most commonly surveyed areas in Socotra Island. Therefore, the disappearance is not likely to be an artefact of undersampling (Van Damme and Banfield 2011). The Phantom Flutterer is widespread in Africa below the Sahel; Socotra was one of the last disjunct northern (and eastern) localities in the species' range; the 


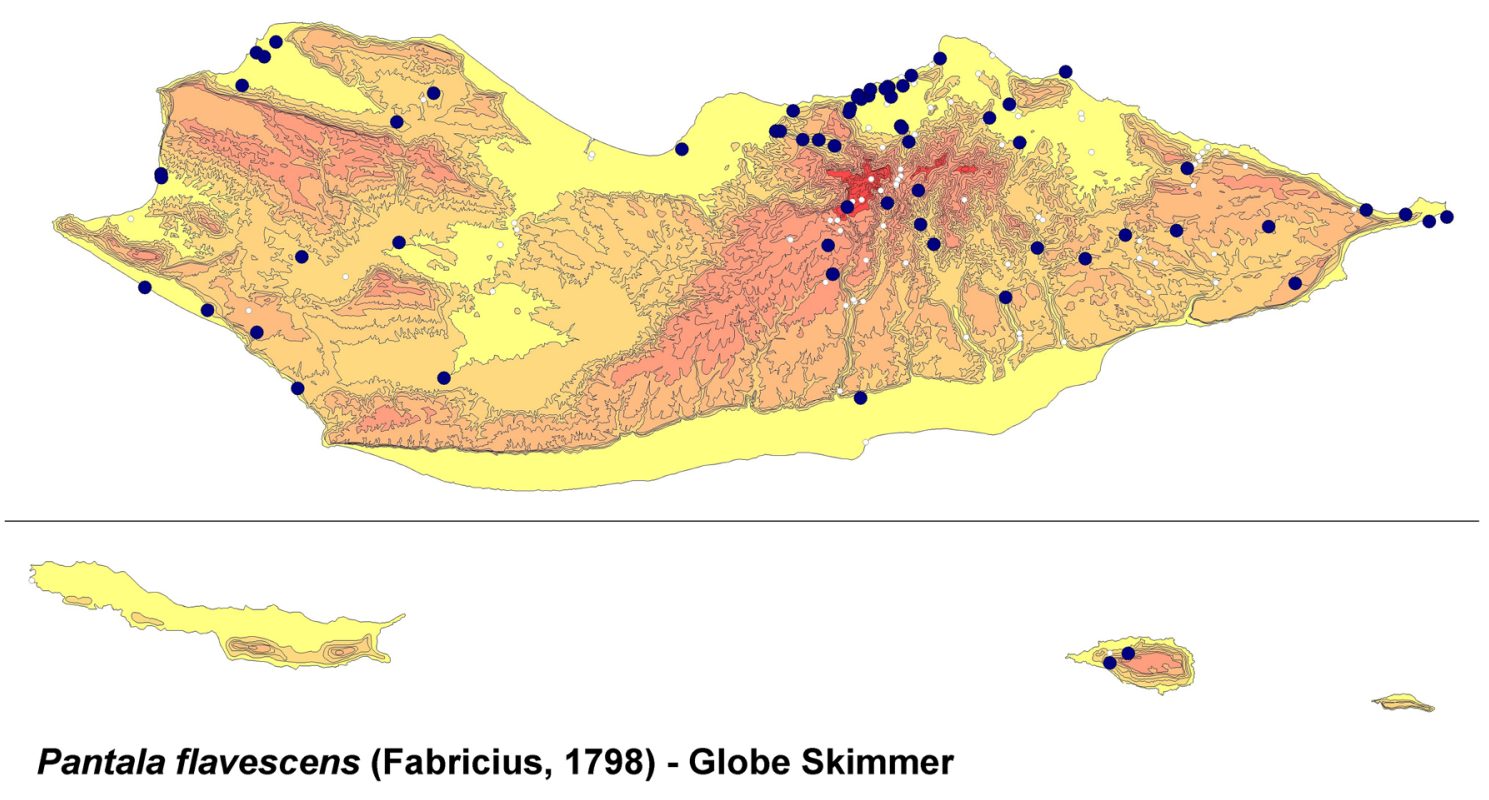

Fig. 22 Distribution of Pantala flavescens in the Socotra Archipelago (Yemen)

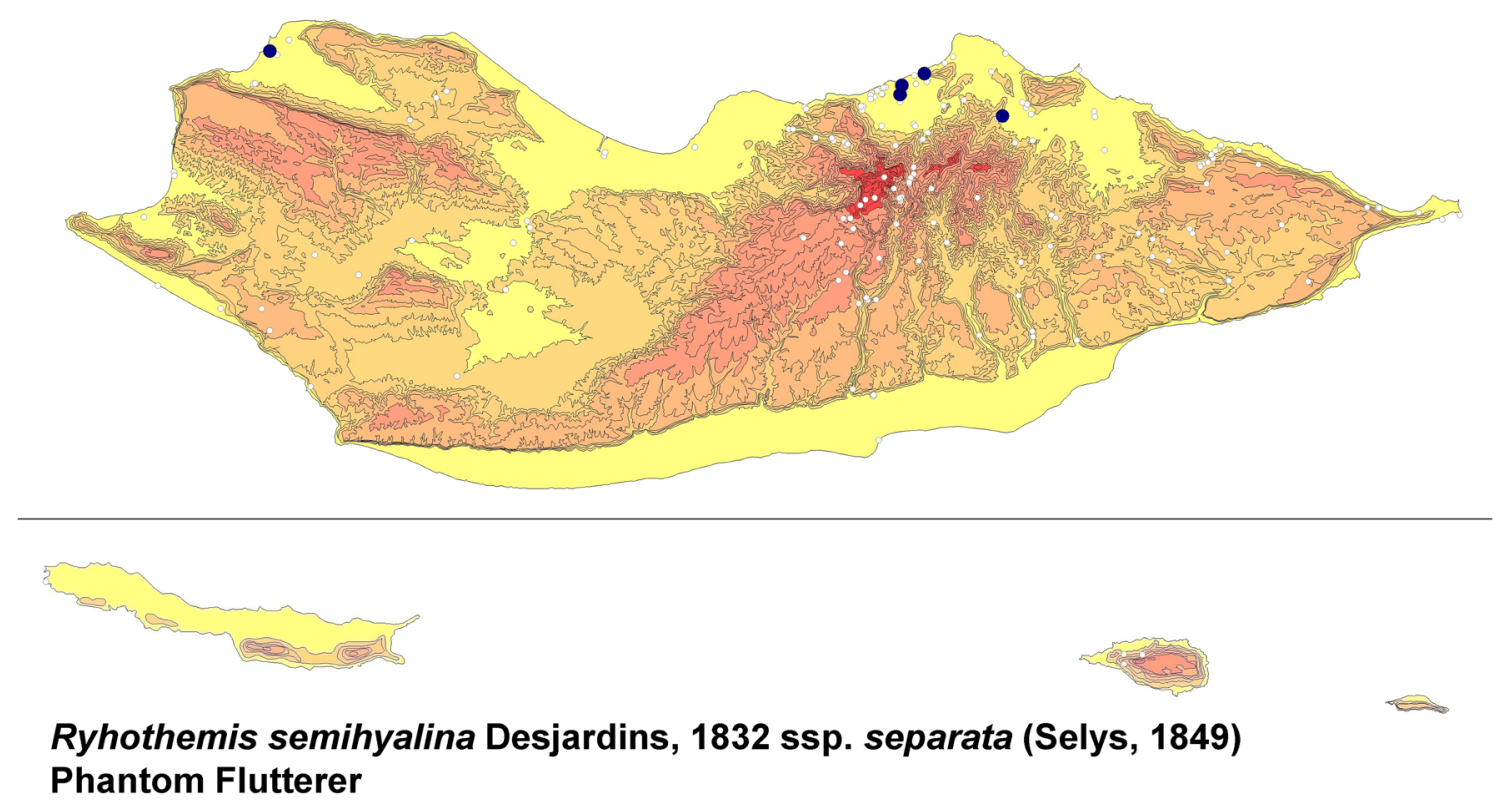

Fig. 23 Distribution of Rhyothemis semihyalina separata in the Socotra Archipelago (Yemen). Note that the species has not been recorded from Socotra since 1953

only remaining Arabian populations known are in Dhofar (Waterston and Pittaway 1991; Lambret et al. 2017); also extinct in Algeria and Israel (Boudot et al. 2016c).

\section{Sympetrum fonscolombii (Selys, 1840)—Red-veined Darter}

(Fig. 24 map)
Recorded only once from Socotra Island, collected in 1999 in Wadi Kilisan (Fig. 24) by H. Pohl, at ca. $100 \mathrm{~m}$ altitude (Schneider and Nasher 2013). In this area, Wadi Kilisan is a deep valley that harbours a large number of pools and areas with slow running water (October-April) between large boulders. The red males of $S$. fonscolombii are easily recognized by the blue underside of the eyes, the pale pterostigma outlined in black and the coloured wing veins; close attention is needed 


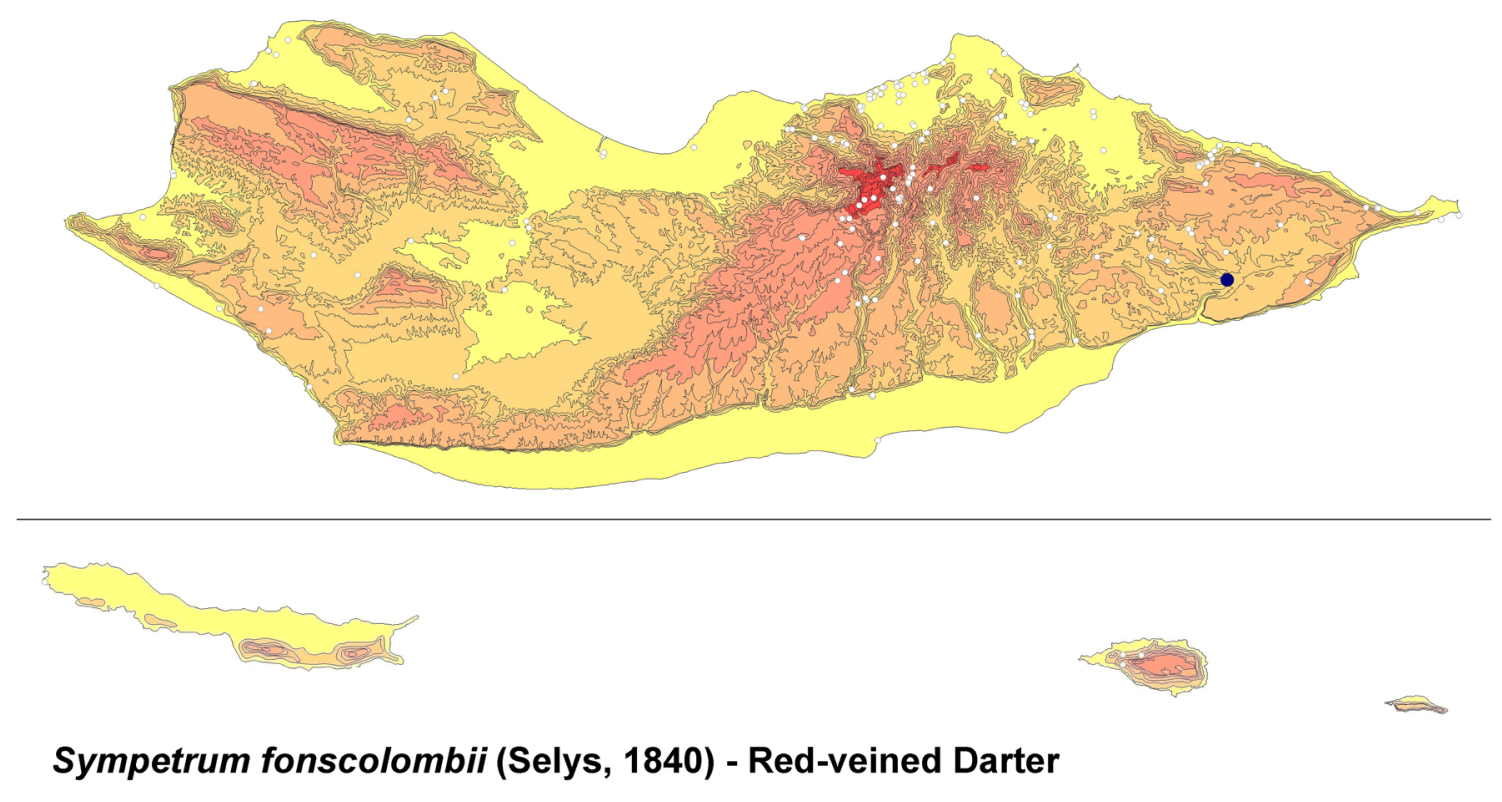

Fig. 24 Distribution of Sympetrum fonscolombii in the Socotra Archipelago (Yemen)

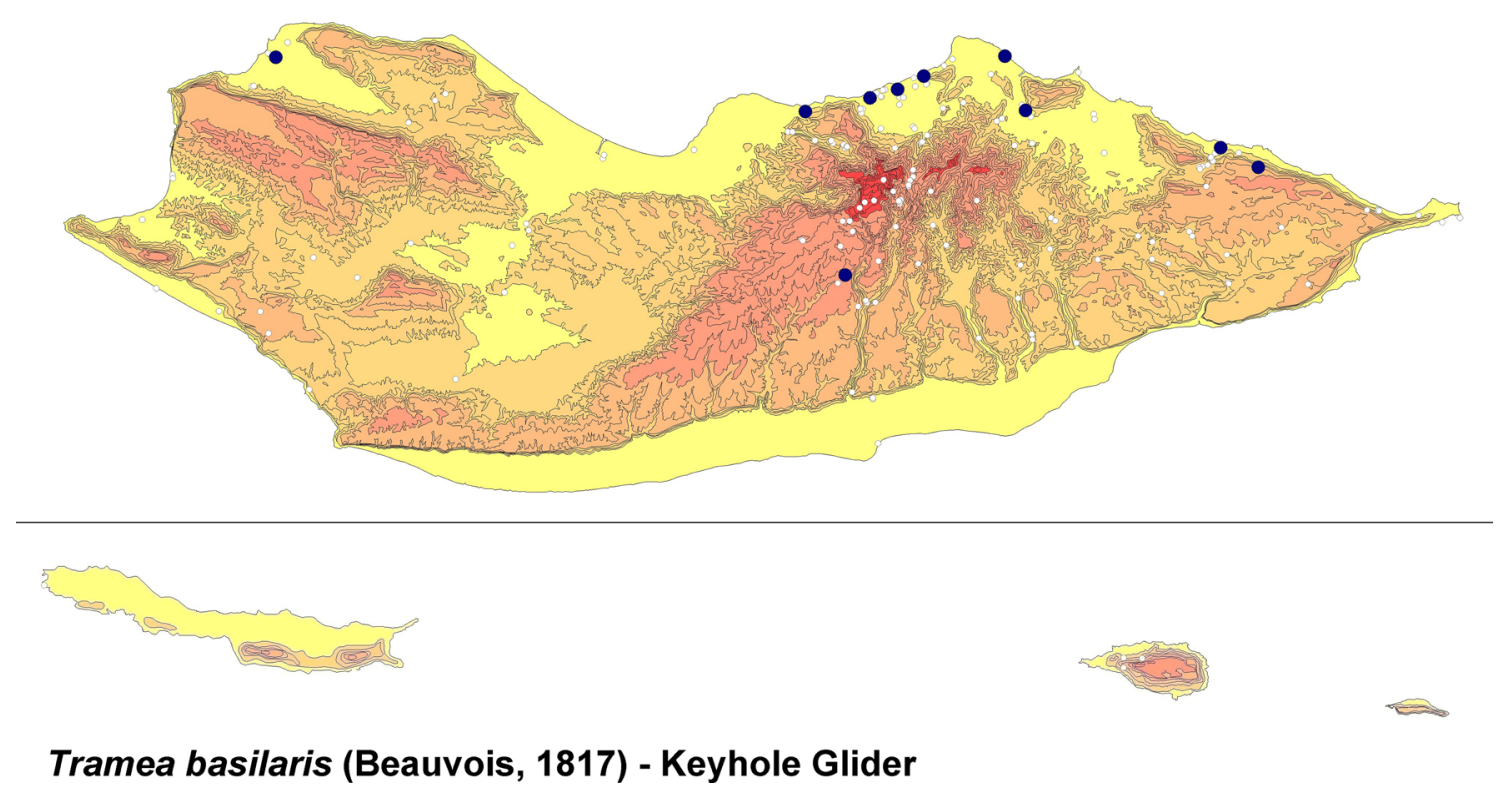

Fig. 25 Distribution of Tramea basilaris in the Socotra Archipelago (Yemen)

to determine its presence and distribution in Socotra. The species can be considered as rather rare in the Arabian Peninsula, illustrated by the limited number of records in Oman and UAE despite intensive surveys (Lampret et al. 2017). Its range covers Europe, Africa, Madagascar and Asia; it is a strong migrant with wide distribution in the paleotropics (Schneider and Nasher 2013; Dijkstra and Clausnitzer 2014).

\section{Tramea basilaris (Beauvois, 1817)—Keyhole Glider}

(Fig. 21d habitus; Fig. 25 map)

Rare in Socotra (1\% of the records, only 10 observations; Fig. 25). Not in the outer islands. Although this species has a broad ecology, T. basilaris (Fig. 21d) is mainly found in 


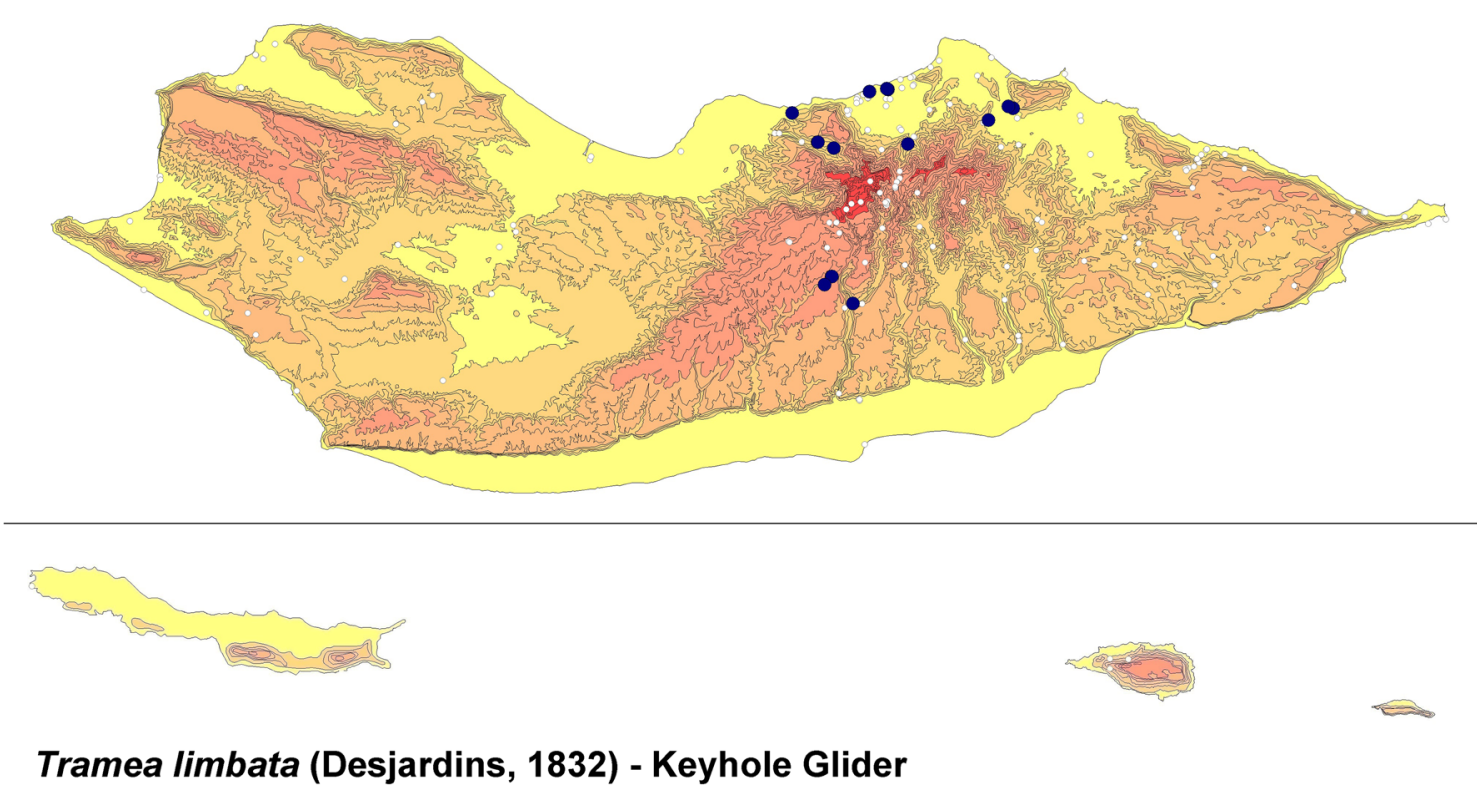

Fig. 26 Distribution of Tramea limbata in the Socotra Archipelago (Yemen)
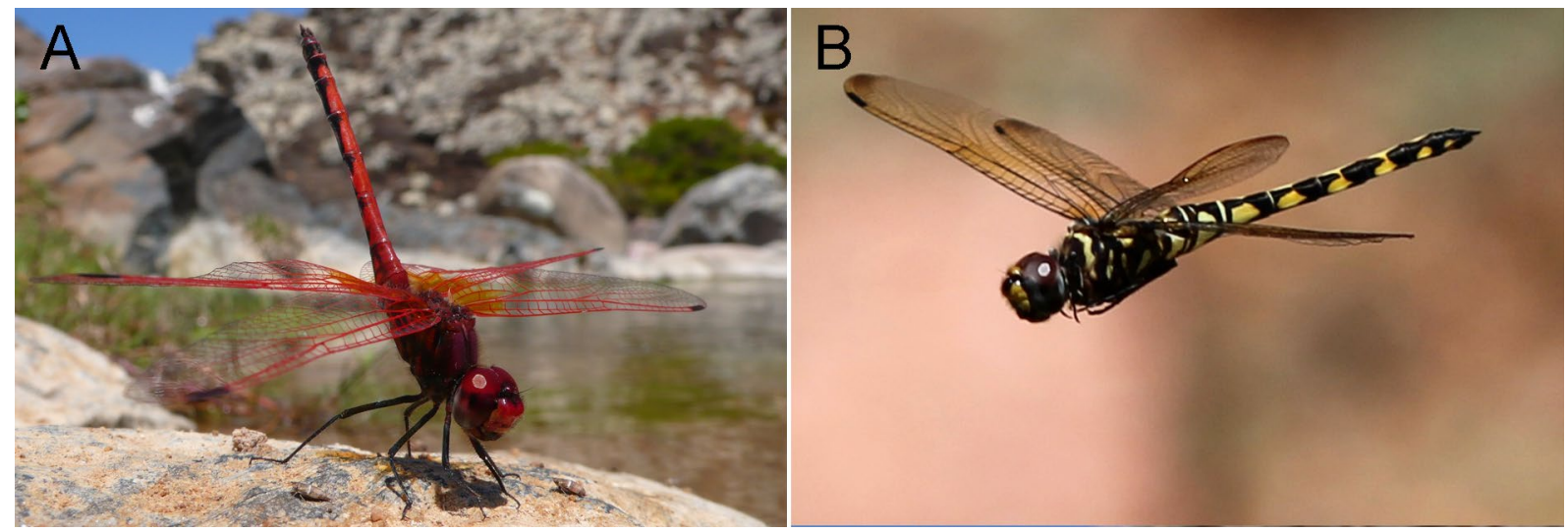

Fig. 27 Libellulidae (Anisoptera) from the Socotra Archipelago. a Trithemis arteriosa male; b Zygonyx torridus male. a photo R. Ketelaar, DiHashus, Socotra Island, 26-02-2009, b photo R. Ketelaar, Wadi Dineghan, Socotra Island, 01-11-2010

the coastal areas of northeast Socotra where it occurs in brackish lagoons and coastal wadis, mostly in low numbers. First collected in the Hadiboh plain in the north in 1898 (MacLachlan 1903, as T. burmeisteri Kirby, 1889) where it was still found in 2010. Present in brackish waters at Qadhub (Riservato et al. 2010), Sirihin Lagoon and also in Qalansiyah Lagoon in the west. We confirmed breeding at Wadi Ma'ābadh west of Hadiboh on the northeastern coast. The Keyhole Glider occurs also in pure freshwater lotic environments on the Diksam plateau. The altitude over its entire range in Socotra is 0-600 m (Fig. 25). In the field, T. basilaris (Fig. 21d) and T. limbata (Figs. 21e, f) can be easily confused; therefore specimens should be examined closely. Both species are widespread in Africa and parts of Asia (Dijkstra and Clausnitzer 2014). The Keyhole Glider is mainly considered an Indian migrant in Arabia (Lambret et al. 2017), herein reported to breed on Socotra for the first time.

\section{Tramea limbata (Desjardins, 1832)_Voyaging Glider}

(Figs. 21e, f habitus; Fig. 26 map)

Rare in Socotra (2\% of the records, or 18 observations), found mainly in the northern coastal areas in permanent 

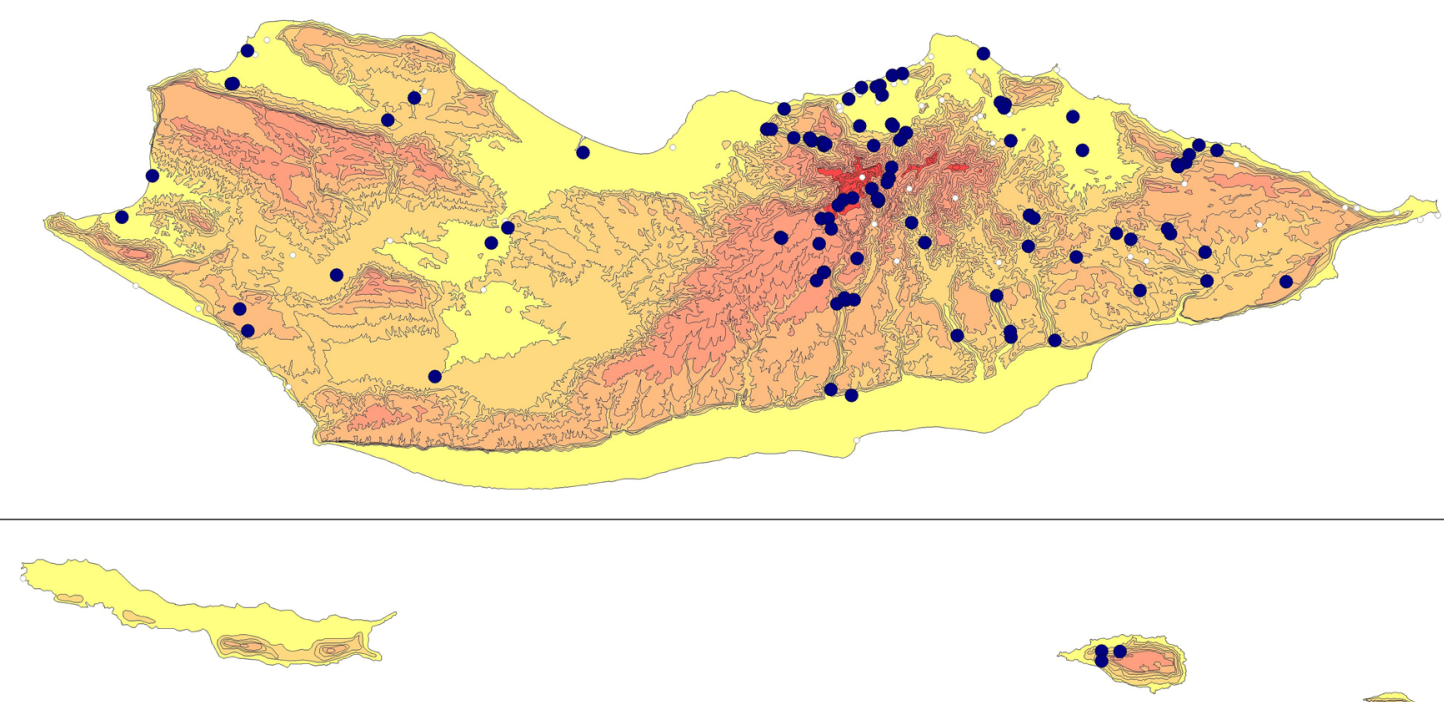

\section{Trithemis arteriosa (Burmeister, 1839) - Red-veined Dropwing}

Fig. 28 Distribution of Trithemis arteriosa in the Socotra Archipelago (Yemen)

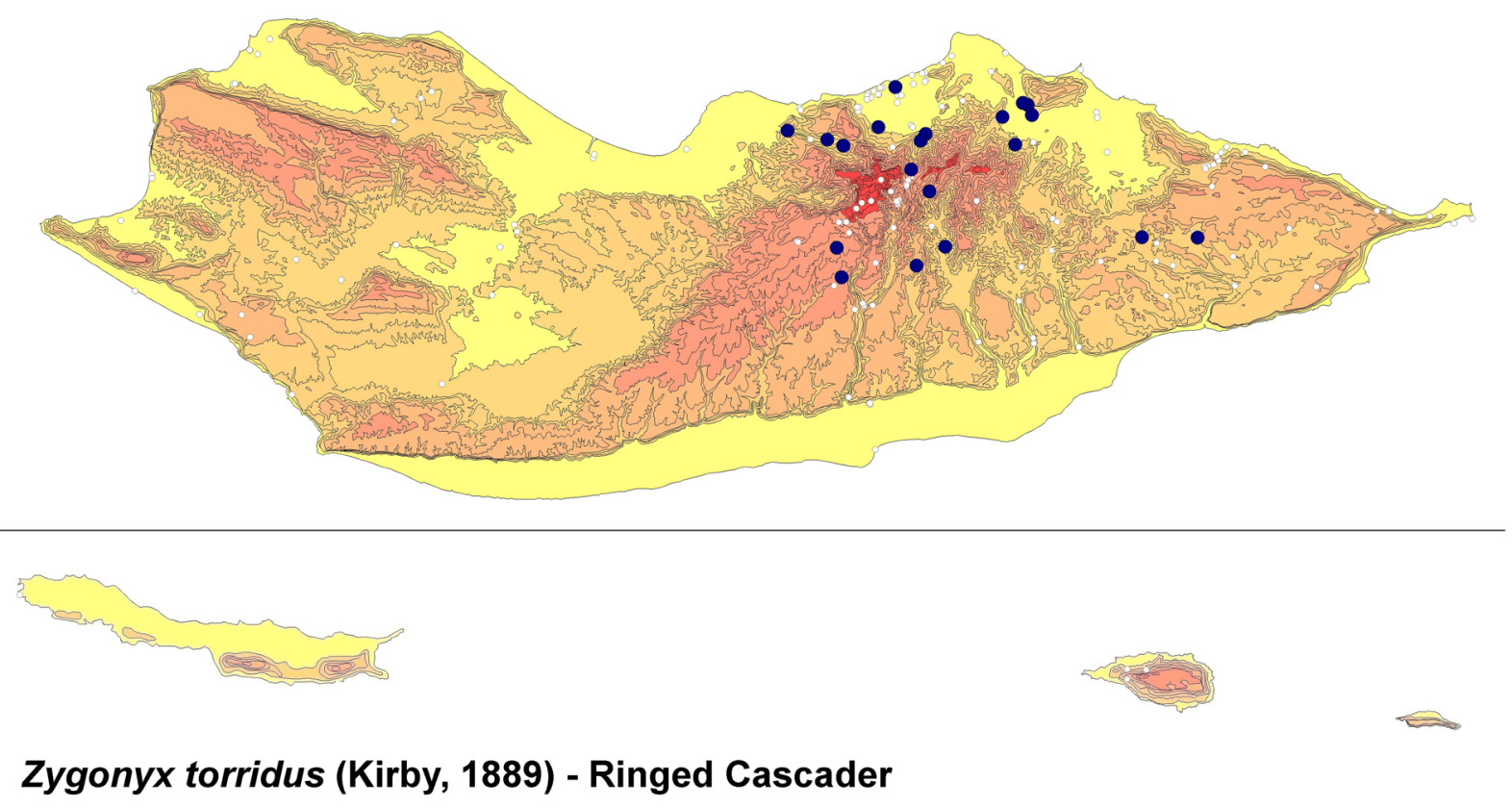

Fig. 29 Distribution of Zygonyx torridus in the Socotra Archipelago (Yemen)

brackish and freshwater habitats (Fig. 26). Not in the outer islands. The first record dates to 1953, when T. limbata was found in the Hadiboh area (Kimmins 1960). Currently present in coastal lagoons and estuaries in the Hadiboh Plain and at Qadhub, and in permanent freshwater wadis in the north such as 'Ayhaft and Dineghan. We observed breeding of this species in Wadi Dineghan. Also found in the interior of Socotra on the Diksam plateau at Wadi Ziyreg and
Wadi Dirhur near Firmihin. All records are in the eastern half and most in the northeast of Socotra. Total area of occupancy on Socotra where this species is currently known is small (ca. $270 \mathrm{~km}^{2}$ ). Altitude over its entire range in Socotra 0-600 m. Listed as Trapezostigma Hagen, 1849 in Wranik (2003). Wide distribution in Africa and Asia, however not present in northern Africa; absent in most of the Arabian Peninsula except for the southern margin in southern and 
central areas of Oman, and in Socotra (Clausnitzer 2016b; Lambret et al. 2017).

\section{Trithemis arteriosa (Burmeister, 1839)—Red-veined Dropwing}

(Fig. 27a habitus; Fig. 28 map)
The most common and widespread dragonfly in Socotra (Fig. 28), occurring east and west of the main island in a wide range of habitats including freshwater, brackish, lotic and lentic ecosystems. Constitutes ca. 14\% of all records in our database. Also on Samha Island (Fig. 28). Pinhey (1970) suggested a separate form for the Socotran populations, Trithemis arteriosa forma socotrensis Pinhey, 1970; however, the latter name is not accepted until new evidence
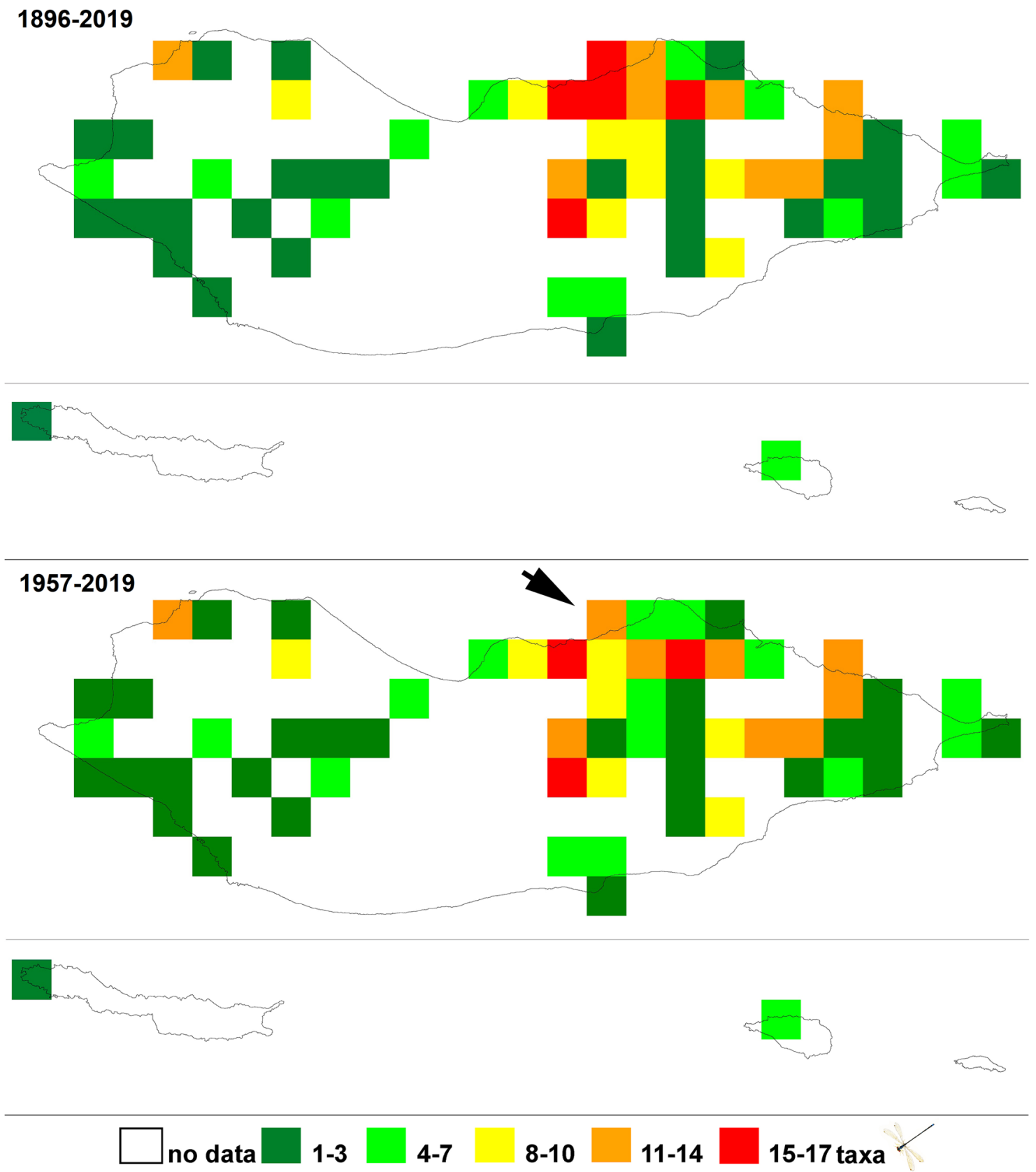

Fig. 30 Species richness of the Odonata in the Socotra Archipelago (Yemen) in $5 \times 5 \mathrm{~km}$ squares and five classes, ranging from relatively very low (1-3), low (4-7), medium (8-10), high (11-14) to very high richness (15-17 taxa). Empty squares lack records. Map above, all
841 records covering the period 1896 to 2019. Map below, a subset of 784 records from 1957 to 2019 (in fact, 1988-2019 because of a gap in records in the period 1957-1987) 

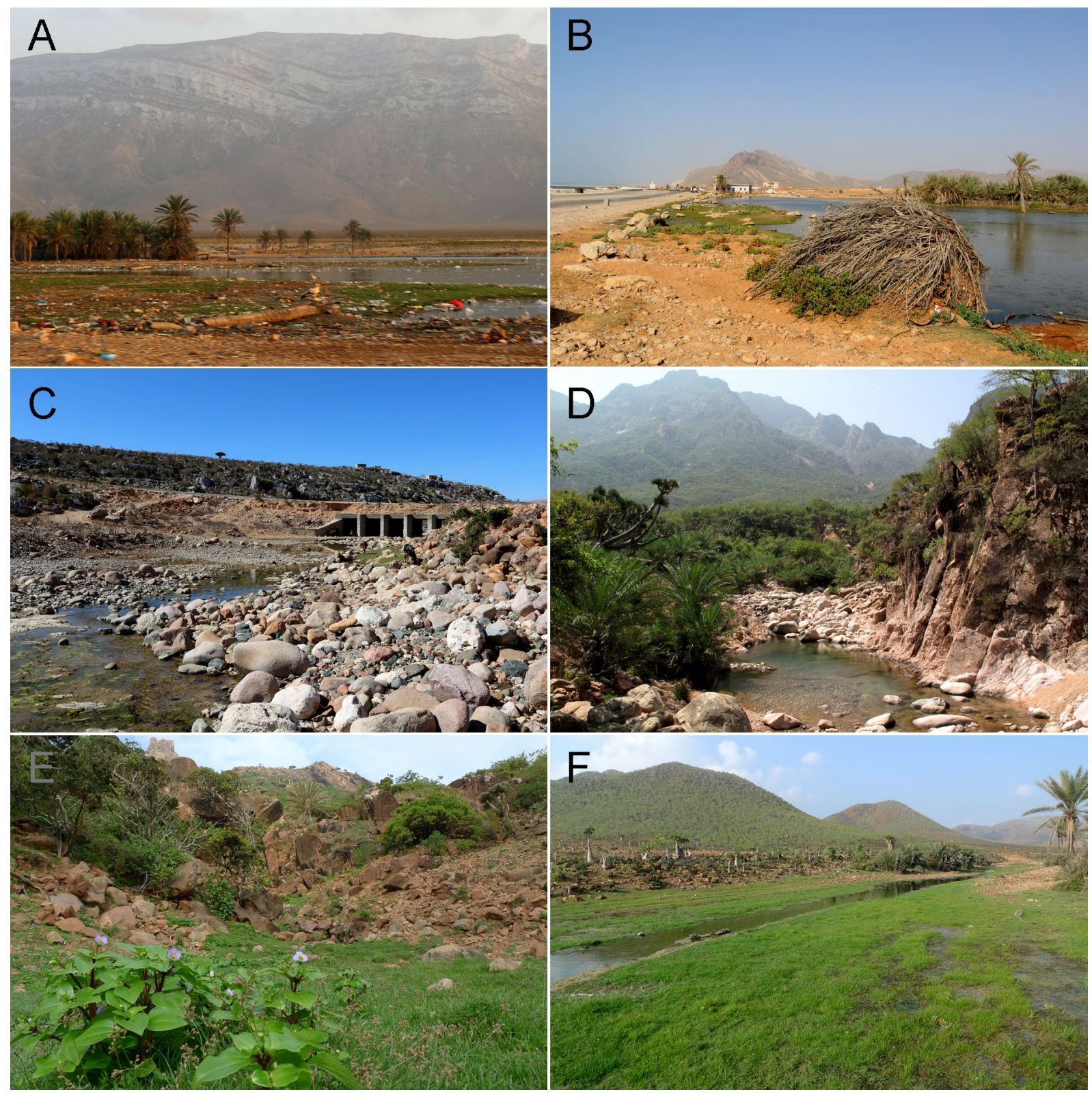

Fig. 31 Biotopes with relatively high Odonata richness on Socotra Island. a Brackish coastal habitats Qalansiyah Lagoon and Wadi Qalansiyah, one of the richest dragonfly areas in the west of Socotra Island. Urbanization and pollution from waste form a threat to this locality. Contains Tramea basilaris, Orthetrum sabina, Ischnura senegalensis and Macrodiplax cora. In 1896, Rhyothemis semihyalina was found here, now extinct on Socotra. Photo KVD, April 2019. b The brackish Sirihin Lagoon is fed by small freshwater streams at sea level, hosting pioneer and thermophilic species like Pantala flavescens, Tramea basilaris, Ischnura senegalensis and Crocothemis erythraea, as well as the halophilic Macrodiplax cora. Also one of the few areas with Hemianax ephippiger. One of the largest populations of Orthetrum sabina on Socotra is found here. Urban developments form an increasing threat as the Hadiboh Plain is rapidly changing. Photo KVD, April 2019. c Wadi Ziyreg on Diksam Plateau is one of the richest dragonfly areas on the island. It harbors one of the largest populations of the endemic Azuragrion granti. Road developments affect part of the stream. Photo KVD, April 2019. d Wadi 'Ayhaft, coming down from the Hageher Mountains, contains a series of wadi pools and well vegetated banks, and clean flowing waters in several upland areas. Rich in species, and an important habitat for A. granti and Zygonyx torridus. Photo R. Felix, 22-02-2009. e Small freshwater wetlands and marshes at 900-1200 m elevation on Socotra are important for rare species such as Orthetrum julia falsum and the endemic A. granti. Also the single record of A. somalicum amitinum is from this type of habitat. Photo RK, "Adho di-Meleh, 05-11-2010. f Wadi Shilliyin in Momi, an open, grassy wetland with small streams is one of the richest dragonfly sites in the east. This wadi holds one of the largest populations of the locally rare A. nigridorsum. Also Ceriagrion glabrum, Ischnura senegalensis and Diplacodes levebvrii are common in this locality. Photo RK, 02-11-2010 
would suggest otherwise. Typically perching on boulders and vegetation near the water (Fig. 27a), also in areas on Socotra with little or no vegetation. The Red-veined Dropwing is present from the coastal lowlands and the plateaus to the mountains, from sea level to $1200 \mathrm{~m}$ altitude. At pools and fast and slow-flowing streams in Socotra it is a typical species, reaching high local densities. Also commonly found at man-made reservoirs, artificial lakes and dug wells; on the coast of Samha Island, the species is present at artificial waterholes. Appears in sheltered as well as open areas, but mainly in the latter. Trithemis arteriosa is a very common and widespread species in Africa (Pinhey 1970); the species reaches the Arabian Peninsula in the east and southern Europe in the north (Boudot and Ferreira 2015).

\section{Zygonyx torridus (Kirby, 1889)—Ringed Cascader}

(Fig. 27b habitus; Fig. 29 map)

Not common (3\% of all records) (Fig. 29). Habitat-specific, typical for clear fast-flowing sections of wadis with wellvegetated banks. The total area of occupancy is relatively small on Socotra, about $400 \mathrm{~km}^{2}$. Not on the outer islands (Fig. 29). First recorded in 1956 (Kimmins 1960). This species has not been recorded thus far beyond the eastern half of the main island and therefore avoids the more arid parts which largely lack permanent well-vegetated waters. The Ringed Cascader (Fig. 27b) is locally not a common or abundant species. It is mainly found in fast-flowing areas of Wadi 'Ayhaft, Wadi Ziyreg and Wadi Dineghan, an indicator of clear and healthy lotic waters, at elevations of 0-800 m. One record at Sirihin Lagoon near Hadiboh is unusual, as this species is not seen on the island in coastal brackish environmentsl however as strong fliers (Fig. 27b), they may venture far along wadis down to the coast. It ranges from the Canary islands and southern Europe throughout sub-Saharan Africa and the Arabian Peninsula to India (Boudot and De Knijf 2015); its distribution in the Arabian Peninsula (e.g. UAE, Oman) and Northern Africa is fragmented (Dow et al. 2016; Lambret et al. 2017).

\subsection{Records per species}

Of a total of 841 observations, the most commonly recorded species are (in decreasing order by number of records, in percentage): . arteriosa (13.8\%), C. erythraea (10.4\%), O. chrysostigma (10.1\%), P. flavescens (9.3\%), I. senegalensis (8.2\%) and A. granti (8.2\%). Common are $O$. sabina (6.9\%), D. lefebvrii (6.3\%). Less common to rare: A. imperator (4.9\%), C. glabrum (4.3\%), M. cora (3.6\%), Paragomphus genei (3.2\%), Z. torridus (2.6\%), T. limbata $(2.1 \%)$ and $H$. ephippiger (2\%). Very rare species are $A$. nigridorsum (1.4\%), T. basilaris (1.2\%) and $O$. julia falsum (0.5\%), Single records include three species, Anax indicus? (A. guttatus-group), Azuragrion somalicum amitinum and $S$. fonscolombii. One species, $R$. semihyalina $(0.6 \%)$, is locally extinct.

\subsection{Species Richness}

(Fig. 30 maps; Fig. 31 habitats)

The point-to-grid analysis $(5 \times 5 \mathrm{~km}$ squares $)$, based on all records, resulted in five richness classes ranging between 1 and 17 taxa per square (Fig. 30). We consider these classes as representing locally relatively very low (1-3), low (4-7), medium (8-10), high (11-14) to very high dragonfly richness (15-17 taxa). Empty squares lack records; these areas were not surveyed or visited, but lacked suitable aquatic habitats during the period when surveys were carried out (October-April). We performed two analyses, the first spanning the years 1896-2019 (full dataset, all 841 records); in the second analysis we excluded all earlier records (the years 1896-1956), therefore covering the period 1957-2019 (784 records). There are large temporal gaps in the surveys. The first record after 1956 appears in 1988; 1960 could be used here as an arbitrary date between the two datasets; the 1960s also correspond to the period when recent developments on Socotra started (Van Damme and Banfield 2011), however the second period of dragonfly observations in reality covers the records of the years 1988-2019 due to an observation gap in the years 1957-1987.

The complete dataset (years 1896-2019; Fig. 30) shows a relatively low Odonata richness in the southwestern quarter of Socotra Island with seven taxa maximally; most western areas have no records or up to three taxa. In the northwest quarter of Socotra, the richness is very low to low, and two areas show medium to high odonate richness; the relatively highest richness in the western half of Socotra Island is in the Qalansiyah area which includes Qalansiyah Lagoon, Wadi Qalansiyah and Qaysoh wetland (11-14 taxa; Figs. 30 and 31a).

The eastern half of Socotra Island harbours a higher richness than the west. Some areas in the northeastern lowlands, the wadis along northern flanks of the Hageher and the high Diksam plateau contain the highest Odonata richness observed in the archipelago (15-17 taxa). The richest areas include (in the north) the Hadiboh Plain estuaries and lagoons (Fig. 31B), Wadi 'Ayhaft (Fig. 31d) and other wadis down from the Hageher towards the north such as Wadi Dineghan, and more central, Wadi Ziyreg (Fig. 31c) and Dirhur in Diksam. The Hageher area itself is not completely studied (empty squares), but surveyed areas shows a relatively high richness as this area harbours suitable freshwater habitats (Fig. 31e). Other areas with high richness (11-14 
Table 1 Terms for dragonflies in the unique Socotri language (identified in this study)

\begin{tabular}{|c|c|}
\hline Socotri term & Translation \\
\hline $\begin{array}{l}\text { 'idbihir } \\
\text { (plural } \hat{\imath}^{’} d b ə h u r \text { ) }\end{array}$ & $\begin{array}{l}\text { 'armoured flying insect (that stings)'; more general 'flying insect that } \\
\text { makes a buzzing noise'. In itself, the word is used for hornets, wasps, } \\
\text { bees (Hymenoptera); sometimes for hover- and robber flies }\end{array}$ \\
\hline 'ídbihir di-a $a^{\varphi} a \mathrm{k} o \mathrm{k}$ & 'Ídbihir of stagnant wadi pools' (dragonfly) \\
\hline${ }^{`} i d b i h i r d i-{ }^{-} \bar{a} r \partial f$ & 'ídbihir of reeds' (dragonfly) \\
\hline 'ídbihir di-ḳat & '’́dbihir of rock pools' (dragonfly) \\
\hline 'ídbihir di-māsṣa & '?idbihir of wet, marshy places' (dragonfly) \\
\hline 'idbihir di-nafrēri & 'I'dbihir with two major wings' (antlion or dragonfly; West Socotra only) \\
\hline 'ídbihir di-rīho & 'Ídbihir of (sweet) water' (dragonfly; most common term) \\
\hline
\end{tabular}

taxa) in the eastern half of Socotra include the Homhil area along the escarpment and a shallow wadi system in Momi, Wadi Shilliyin (Fig. 31f). In the outer islands, Odonata richness is very low to low: only one species in Abd al Kuri, five species in Samha and none in Darsa.

The first analysis accumulates 123 years of observations, therefore total richness in some areas may be different from today. To examine changes over time, we performed a second analysis excluding all records between 1896 and 1956 (retaining all records 1957-2019 which in fact cover the period 1988-2019; Fig. 30 below). The general pattern of relatively rich areas in the second analysis (1957-2019; in reality 1988-2019 because of the gap in records) is similar to the full dataset (1896-2019) when compared within each dataset. Comparison between the two datasets (Fig. 30) shows, however, a relatively lower Odonata richness in several squares in the 1957-2019 (in fact, 1988-2019) dataset (Fig. 30 below), in particular in the Hadiboh Plain area. This is most noticeable along the northeastern coast in the area between Hadiboh and Hawlaf and from Hadiboh directly $5 \mathrm{~km}$ towards the south, where the difference in taxa is five (from 12 to 7 taxa between Hadiboh and Hawlaf, and from 15 to 10 just south of Hadiboh) when compared between the first period (until 1956) and the second one (since 1988). A difference of five taxa corresponds to $29 \%$ of the recorded maximum number of species (17) in our $5 \times 5 \mathrm{~km}$ grid. The northeastern coastal lagoons seem to retain a relatively similar number of species in the two periods, from 15 to 14 , which is still relatively high. Two areas in the Hageher covering the higher courses of Wadi Dineghan towards 'Adho di-Meleh show a difference in class as well, but these are small (1-2 taxa) and can be attributed to missing observations. In the west, the difference in the number of species until 1956 compared to those found after (i.e. since 1988) is small, therefore the class remains the same (12 taxa before, 11 after). The analysis of the 1957-2019 dataset (Fig. 30 below) is further similar to the full dataset (Fig. 30 above), as $93 \%$ of all records date from 1988 onwards; therefore, one cannot simply derive a status quo for all squares that fall under the same richness class in both analyses.

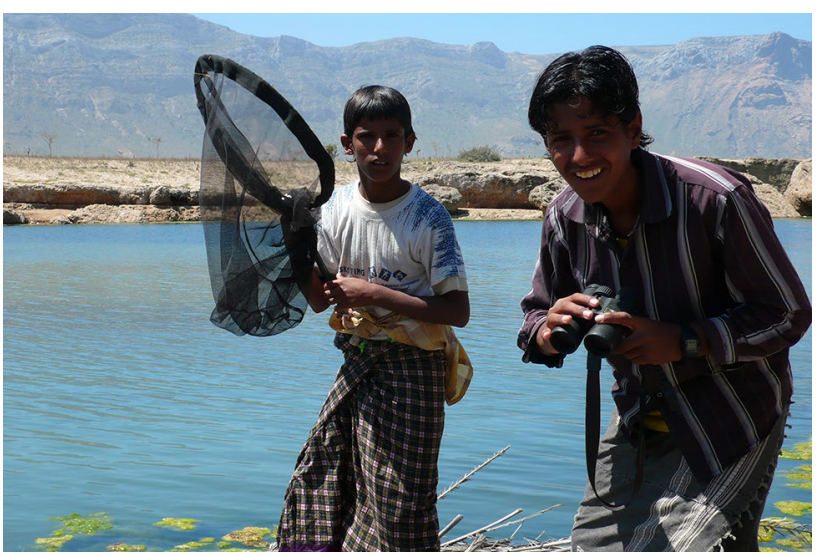

Fig. 32 The indigenous people of Socotra have at least six terms for dragonflies in their unique language. The general value of these animals, as indicators of healthy aquatic habitats, is known on the island. Photo: young Socotri showing interest in dragonfly observations during the surveys (RK, Wadi Qalansiyah, 2010)

\subsection{Local description and perception of Odonata}

The indigenous people of Socotra Island have several names for dragon- and damselflies in their unique and endangered Socotri language. A basic list of Socotri words for different animals is found in Wranik (2003:509). To assess the potential of the Socotran dragonflies for awareness purposes in aquatic biodiversity conservation, notes on the perception and local descriptions of Odonata are included here.

The Socotri use a general term for dragonflies by compounding nouns, the first linked to general traits of the animal, and the last linked to the habitat. The first noun is 'idbihir, plural $\imath^{\text {' }}$ dbohur, on itself an 'armoured flying insect (that stings)' or, more generally, a 'flying insect that makes a buzzing noise'. The noun is commonly used for hymenopterans, hornets in particular, for wasps and, bees, but also for hover- and robber flies. In combination with a second noun, the term becomes more specific, for example, bees are 'idbihir di-'asal ('idbihir of honey'). 
We found at least six compound terms for Odonata in the indigenous Socotri language besides the generic 'idbihir (Table 1). The most general term for dragonfly is 'idbihir di-rīho ('idbihir of (sweet) water') which could be loosely translated as 'flying buzzing insect of the water' or very general as 'water wasp' or 'water bee'. The word rīho refers primarily to potable water. The use of the first noun "${ }^{\varsigma} i d b i h i r$ is based on a general morphological similarity with large hymenopterans and the fact that these animals make a sound when flying.

Other names relate to more specific habitats, such as permanent shallow well-vegetated wetlands, which are particularly common in higher regions: 'ídbihir di-`ंärof ("'idbihir of reeds'), linked to habitats with Cladium species or ${ }^{\varsigma} \bar{a}$ rəf, a sedge common in damp soil along wadis coming down from the Hageher (Miller and Morris 2004) and 'íbihir di-māśa ('idbihir of wet, marshy places') containing $m \overline{o s ̣ a}$ or $m \bar{a} s ̦ a$, 'damp, marshy area', a word also used for Gramineae and Cyperaceae growing in these environments. Dragonflies of temporary waters: Pidbihir di-kat ("'idbihir of rock pools') and 'idbihir di-a'akok ("'idbihir of stagnant wadi pools'), the latter from 'iș $\partial$, plural $a^{\varsigma} a \mathrm{k} o \mathrm{k}$, 'small pool remaining in a wadi bed after rains'. We found no terms linking Odonata to brackish habitats. In western Socotra, people also use a general term 'ídbihir di-nəfrēri ('`idbihir with two major wings'), which according to Wranik (2003) may refer to antlions and ribbon-wings (Neuroptera); we consider it likely that Odonata and larger Neuroptera are sometimes lumped under this term. Dragonflies are separated in the Socotri language from other winged insects such as mosquitoes, grasshoppers and butterflies, which are described by different words (Wranik 2003). For example, the term for butterflies is šanșahāni, from the verb 'to open, split; to spread'.

Several young people whom we asked to name dragonflies, based on photographs during recent surveys (2019-2020), did not know the Socotri names. If the Socotri name was known, they referred to dragonflies more generally as 'idbihir, and on one occasion as 'idbihir di-șirzher ("idbihir that makes repeated sounds'); the latter is incorrect, as this is a Socotri term for cicadas and crickets that make repeated high calls at the height of the summer heat.

Indigenous communities in Socotra Island have a generally neutral to moderately positive attitude towards Odonata (Fig. 32). Local people describe these insects as harmless and amusing, aware that dragonflies do not sting. People do not kill or eat them; dragonflies do not play an important role in local folklore, hence the animals do not appear in stories or songs. Local people in Socotra, as indeed in most areas in the world, are not aware of the ecological roles of Odonata as predators of other arthropods. However, the connection to aquatic habitats is observed in the local language (water, reeds, marshes, temporary pools; Table 1). As the most common term 'idbihir di-rīho connects the animals to clean drinking water, the perception of the local people is often more positive than neutral. To illustrate the local perception, we include the following, translated from Socotri about 'ídbihir di-rīho (sound records Morris 1980-1990, unpubl. data): "We hear them when they fly, their wings make a clear buzzing sound. They are only ever found around sweet water. They like pools and puddles, running water and places with reeds and rushes, rock pools and water holes or you see them flying around plants growing in the vicinity of water. They are harmless and we never harm them. As children we used to creep up on them and try and catch them! If we managed to catch one we'd then play with it. We'd hold onto one wing and let the other go and listen to it go whirrrrrrr as it flew its other wings. Then we'd let it go. We'd never kill it: it doesn't bite and it isn't poisonous. They fly from place to place in a zigzag manner." The latter is based on accounts collected 40 years ago.

Contemporary impressions about dragonflies included the following statements by bedouins from the eastern interior (A.Y. Mahroos 2020 pers. comm.): "When these insects are flying around a certain wadi, it means the wadi is still clear and not dirty because of waste." and "they indicate rain and clean and clear water."; "they are around sweet water, never salty water". The statements link dragonflies to the quality of the aquatic environment. The local perception that dragonflies do not thrive well in waters without waste is recent, because waste has now visibly increased around larger settlements (Fig. 31a). Indigenous inhabitants of the interior, primary custodians of the rich Socotri language, look down on the pollution of waters near Hadiboh, as opposed to the clean waters at higher elevations.

As conspicuous animals, Odonata are observed as attractive to foreigners visiting Socotra, ecotourists and naturalists alike. They appear frequently among online nature photographs and descriptions from the island. A journalist, who recently visited the island, described how "iridescent dragonflies swooped and hovered' over a wadi (Carter 2006) and the British entomologist K.M. Guichard described the endemic A. granti as "a beautiful little sky-blue dragonfly" (in Doe 1992). Schneider (1999) wrote about his first impression of A. granti at Wadi Dineghan during a visit with HJD in 1996, "The only dragonfly on the wing was Trithemis arteriosa but, as evening approached, I spotted an azure blue damsel of impressive size disappearing into the riparian vegetation. I netted it and to my delight, it was a male Enallagma granti!". In recent scientific and in popular media, dragonflies from Socotra are mentioned at the same level of interest as birds and reptiles, for example in the book Sanctuary by Tobias and Morrison (2008) or in Sohlman (2004); BBC News (2013) posted a photo of $C$. erythraea resting on a Royal Navy ship offshore Socotra. 


\section{Discussion}

\subsection{New record}

The finding of a hitherto unrecorded Anax from Socotra in Wranik's collection at Prague Museum collection is surprising. As long as only one record is known, we should treat this finding carefully. However, we can expect new additions to the local odonate fauna, as three species have been reported only once (S. fonscolombii, A. somalicum and A. indicus?) and more vagrants are likely. The newly recorded Anax belongs to a strictly Oriental $A$. guttatus group. The closest matches are $A$. indicus and $A$. guttatus, which are not present in Arabia or Africa. However A. guttatus is a known strong flyer that may colonize remote islands such as the Seychelles (Belyshev and Haritonov 1978) and it is possible that such vagrants may reach Socotra by wind. Also M. cora has a primarily Asian origin, although present in Southern Arabia and the Horn of Africa (Dumont 1991; Lambret et al. 2017) and can be seen as an Oriental element on Socotra (McLachlan 1903). Several other isolated populations of Odonata of Asian origin are present in the Arabian Peninsula such as Pseudagrion decorum (Rambur, 1842) and Trithemis pallidinervis (Kirby, 1889) in Oman (Jödicke et al. 2004).

Only one specimen has been found of the potentially third aeschnid on Socotra. In the field, it may be confused with $H$. ephippiger which is widespread on the main island. All the new records in the Socotran odonatofauna of the last decades were found among general morphotypes on the island (e.g. $S$. fonscolombii could be confused with locally common red dragonflies to the untrained eye, A. somalicum with other azurets); therefore, close attention should be given during field surveys.

\subsection{Locally important species}

The majority of Odonata known from Socotra are listed as globally of Least Concern according to the most recent assessments in the IUCN Red List (version 2020-1). Only two taxa have a higher conservation status, the Near Threatened endemic $A$. granti and the Vulnerable subspecies $A$. somalicum amitinum (Schneider et al. 2013, 2018). The Socotra Bluet is one of the few endemic Socotran invertebrates in the IUCN Red List. Both species are threatened and recognized as critical for conservation in northern Africa and the Arabian Peninsula (Jödicke et al. 2004). Even though A. granti is locally widespread in eastern Socotra, it acts as an indicator for clean lotic environments, which should be protected.

In addition to the importance of $A$. granti and A. somalicum, Socotran populations of several species are disjunct and therefore significant within their wider range, such as the Oriental M. cora, for which Socotra is one of the few westernmost localities. Several other species such as A. nigridorsum, M. cora, P. genei, T. limbata and Z. torridus have relatively limited or disjunct distributions in the surrounding mainlands of the Arabian Peninsula and Northern Africa, and the Socotran populations are important. Already local populations of one species with such a disjunct distribution pattern went extinct, $R$. semihyalina, unless populations survive in a few isolated undisturbed brackish sites on the island. Even among the species with a more continuous range, these island populations are relevant. We currently lack genetic data for nearly all dragonflies on Socotra, which could help to assess regional speciation, for example, in T. arteriosa for which Pinhey (1970) suggested a Socotran variety. Molecular data would improve our knowledge about the origins and therefore invasion history of these populations. In addition, local populations of $O$. julia falsum and A. nigridorsum are small and vulnerable to disturbance. Both species occur in specific habitats and might be considered as local indicators for priority areas for conservation.

\subsection{Socotran Odonata Richness}

The maximal richness of up to 17 dragonfly taxa in a given area over decades of observations on Socotra may not seem high. In the richest sites, between six to ten species can be found easily at any given time. Temperate continental areas, for example in western Europe, reach considerably higher dragonfly richness of over 70 species, which is in turn low compared to tropical regions such as the Afrotropics (Kalkman et al. 2008; Clausnitzer et al. 2011; Pinkert et al. 2017). However, compared to the dragonfly diversity recorded per river subcatchment in Arabia only a few areas, mostly situated along the southern margins of the arid peninsula, reach an accumulative richness of 14 dragonfly taxa or higher (up to 29 taxa; Samraoui and Schneider 2015:40). Dhofar is a regional dragonfly hotspot with over 30 species (Lambret et al. 2017). The numbers in Arabia compare well to Northern Africa and most of the Horn of Africa, except for the Maghreb and other areas with higher diversity (Samraoui et al. 2010:58, Clausnitzer et al. 2011:99). The dragonfly diversity of Socotra is therefore not low, in fact it can be considered as relatively high when compared to the predominantly arid mainlands. The total of 21 extant taxa on Socotra also compares well to other western Indian Ocean islands; the Comores and the Seychelles each harbour a similar number of about 20 Odonata species but have proportionally more endemics (Samways 2003a, b), although these islands are considerably smaller in total area than Socotra.

On Socotra Island, diversity of dragonflies is relatively highest in the east. This is also the region where the only endemic species is confined to. The eastern areas are wetter 
due to the presence of the granite mountains and adjacent elevated plateaus catching the moisture (Miller and Morris 2004; Scholte and De Geest 2010; Banfield et al. 2011). Therefore, the east harbours most of the suitable permanent freshwater habitats of the archipelago, areas with the highest local dragonfly diversity. These include well-vegetated and sheltered permanent freshwater streams and deep pools in large valleys such as Wadi 'Ayhaft and Wadi Dineghan, and higher streams, marshes and wetlands in the Diksam and Hageher areas such as Wadi Ziyreg. Several Odonata that depend mainly on permanent waters, like the Ringed Cascader, and all three bluets, are known only from the east. We consider the higher mountain ranges and habitats as the centre of distribution of the endemic Socotra Bluet. These areas are generally rich in biodiversity and endemism on Socotra because they function as wet refugia (Miller and Morris 2004, Banfield et al. 2011). A restriction of several endemics to mainly the eastern half of Socotra can be observed in other groups, for example in plants, such as the Socotra Dragon's Blood Tree Dracaena cinnabari Balfour (Miller and Morris 2004) or in reptiles such as the gecko Pristurus insignoides Arnold, 1986, which is related to high moist habitats in the Hageher mountains (Razzetti et al. 2011).

Among the aquatic insects in the archipelago, important parallels can be noted as well, for example between the dragonflies and the aquatic beetles. Both the hydrophiloid (Fikáček et al. 2012) and adephagous water beetles (Hájek and Reiter 2014) have a similar richness and a relatively low proportion of endemics (17/3 for Adephaga; 16/3 for Hydrophiloidea) when compared to terrestrial beetle families in Socotra (Hájek and Bezděk 2019). Most of the endemics among the aquatic beetles inhabit the streams and wadis in or directly connected to the mountains; the hydrophilid Hemisphaera socotrana Fikáček, Delgado and Gentili, 2012 was described from Wadi Ayhaft, where also A. granti occurs; two endemic dytiscids (Yola wraniki Wewalka, 2004 and Hyphydrus dioscoridis Hájek and Reiter, 2014) are mostly associated with pools in wadis coming from the mountains (Wewalka 2004; Fikáček et al. 2012; Hájek and Reiter 2014). On the other hand, endemics of the minute mud-loving beetles of the genus Georissus Latreille, 1809 (Fikáček et al. 2012) confirm the importance of conservation of the unique biodiversity in the coastal lagoons of eastern and western Socotra. In general, the latter supports that dragonfly richness relates well to that of other freshwater groups within regions (Darwall et al. 2011); therefore, we should consider the richer dragonfly areas in Socotra as important for local conservation of other aquatic invertebrates.

Despite the observed declines, the northeastern coastal area of Socotra, which includes freshwater streams as well as brackish estuaries and lagoons, is a locally relatively rich area for dragonflies. Further east, Wadi Homhil, Wadi Shilliyin and Wadi Kilisan are among the most important sites that have been surveyed, not directly connected to granite mountains, yet harbouring important sheltered freshwater habitats.

In comparison, the western half of Socotra Island and the outer islands are low in dragonfly diversity. This cannot be attributed to sampling bias alone, as there is an actual shortage of permanent surface freshwater habitats in the west. The plateaus in western Socotra lack the elevated granitic pinnacles that are present in the east; therefore, the water in the west percolates through the limestone into subterraneous reservoirs instead of running along deep valleys. Only a few areas in the west harbour significant permanent surface waters, such as Wadi Qalansiyah, Wadi Shu'ub, Neet and the waterfalls at Hazehaz (Berbeher), which need closer study. It is likely that during the monsoons, i.e. outside the common dragonfly surveying period between October and April, temporary freshwater areas may form suitable habitats for rapid colonizers. However, the apparent lack of records of Azuragrion in the west of Socotra Island can be considered as true absence due to a lack of suitable habitats, until new evidence would suggest otherwise. More monitoring efforts and training of local people in identification are needed in general for dragonflies in Socotra. Attention should be given to identification of the larval stages and exuviae to allow for a more comprehensive understanding.

\subsection{Changes in recent decades}

The Odonata make up a small proportion of the Socotran fauna, not diverse or high in endemics when compared to obligate terrestrial groups, or when compared to odonate faunas in other islands of similar size. However, our analysis of records covering over 120 years, even for a small number of taxa and not based on systematic coverage, leads us to suggest changes in richness over time.

Our comparison of the records of the years 1896-2019 versus 1957-2019 indicates a potential decline in the number of Odonata taxa after 1956 (in fact, the next record after 1956 is in 1988) in some areas of the Hadiboh Plain. In these areas, we observe a drop of about a third of the maximum number of taxa recorded in the spatial resolution considered $(5 \times 5 \mathrm{~km})$. This is unlikely to be an artefact due to undersampling, as there are 13 times more dragonfly records after 1956 than before.

Three species have not been recorded from the Hadiboh Plain since the late 1950s: $R$. semihyalina, A. nigridorsum and the endemic $A$. granti. Therefore, the changes in these areas had an impact on at least two types of aquatic habitats: (1) brackish lagoons and estuaries, the typical habitat for $R$. semihyalina, a libellulid which was considered common in eastern and western areas of Socotra, such as Hadiboh and Qalansiyah up to the 1950s; (2) clean sheltered lotic freshwater environments with well-vegetated grassy banks, typical for Azuragrion. We consider the apparently small differences 
as significant and speculate that they result from direct human disturbance in these development areas. Potential natural factors, such as climate-driven impacts like periods of drought, should also be taken into account, but were not studied here. Natural changes may have contributed, together with human impacts, to the disappearance of the once common Phantom Flutterer in Socotra, which also disappeared in Algeria and Israel (Boudot et al. 2016c).

\subsection{Threats and Conservation}

Socotra Island is subjected to a number of challenges affecting the local biodiversity and culture (Van Damme and Banfield 2011). Effects of human disturbance on the invertebrate fauna of surface waters in Socotra have not been investigated until this study. Recent images of coastal waters illustrate the expanding general human disturbance (Fig. 31). Along the northern coast, in particular the Hadiboh Plain, Socotra changes more rapidly than anywhere else, including direct changes in land use as well as infrastructure works; vegetation loss is apparent through overgrazing and cutting for firewood and building. The latter are all factors known to affect dragonfly diversity.

Freshwater streams and important estuaries and lagoons in the coastal lowlands are affected by terrestrial impacts such as infrastructure development, pollution and other direct human disturbance (Wranik 2003; Thieme et al. 2005; Van Damme and Banfield 2011; Porter and Suleiman 2016). The negative effects of urbanization and vegetation removal on dragonfly richness are well known (Villalobos-Jiménez et al. 2016) and have a direct effect on Socotra's waters. Clearing of vegetation, overgrazing, general urbanisation and pollution in the Hadiboh Plain may have reduced the number of suitable habitats for A. granti and A. nigridorsum, which prefer well-vegetated sheltered freshwater streams. On the higher plateaus, climate change (droughts) and effects from overgrazing are more likely to impact the terrestrial (Pietsch and Morris 2010; Van Damme and Banfield 2011) and therefore the aquatic environments. However, overgrazing of banks, fragmentation of streams, like the road through Wadi Ziyreg, water extraction from permanent streams and pollution are realistic all over the island as the human population expands (Fig. 31). Several aquatic sites in coastal areas of Socotra run through date palm plantations or near home gardens which require water; therefore uses of insecticides would affect the animals within.

In addition, although not studied in detail, it is likely that there is an effect of the (still ongoing) anti-malaria campaigns. These include the repeated introductions of exotic populations of the Arabian Toothcarp Aphanius dispar (Rüppell, 1829) in most areas in Socotra since the 1980s and the extensive administration over decades of high amounts of insecticides in lagoons and wadis (Al-Safadi 1998; Wranik
1998; 2003; Van Damme and Banfield 2011), which have most likely impacted non-target aquatic invertebrates such as dragonflies. In spring 2019, we also witnessed insecticides being dumped via a small aircraft directly in Sirihin and Hadiboh lagoon as part of anti-mosquito campaigns, on a weekly basis, and we noted that the general use of insecticides in agriculture has strongly increased. Such increased insecticide activities will affect sensitive invertebrates in these coastal sites, like dragonflies, and therefore have an indirect effect on their consumers as well. A strong local protection of the aquatic habitats is vital, including the designation of new protected areas aimed primarily at protecting the aquatic biota. Such a formal protection is necessary for rich aquatic areas on the plateaus, but also for coastal estuaries and lagoons, in order to maintain the local biodiversity and the quality of these environments.

Several of the locally diverse areas for dragonflies on Socotra are not protected through national or international designations as they are considered as pure development zones in the Socotra Conservation Zoning Plan and the UNESCO World Heritage Property, such as Hadiboh and Qalansiyah areas (UNDP/GEF 2000; UNEP/WCMC 2008). According to our study, these areas actually harbour some of the richest sites for dragonflies, and by extension we should consider these sites important for aquatic biota. In the northern plains of the island, also interesting shallow temporary waters occur that are vulnerable, harbouring important invertebrate taxa (Van Damme 2018). In general, there are no management plans for conservation of surface waters in Socotra, or for protecting the vegetation and soils bordering main waters. Habitats which are currently under pressure such as the northeastern coastal lowlands, and the relatively less directly pressured eastern highlands are important to local biodiversity beyond dragonflies. The estuaries and lagoons on Socotra play a crucial role in maintaining biodiversity of vertebrates such as fish and birds (Lavergne et al. 2016; Porter and Suleiman 2016). The higher elevation areas would be susceptible to overgrazing, soil erosion and climate change, but suffer at present less from direct development other than road building and potential water extraction (Van Damme and Banfield 2011). Without intervention, the trend is likely that impacts on aquatic habitats in the coastal plains and beyond in Socotra will increase, risking declines in local biodiversity.

Finally, the erosion of the rich local language risks a loss of the link between the people and their natural environment (Miller and Morris 2004; Van Damme and Banfield 2011). This includes a small group on the island such as dragonflies for which we identified no less than six local terms. The local perception towards dragonflies is generally neutral to positive. These animals are recognized by the islanders as harmless and as indicators of clean freshwater environments. Therefore, the Odonata of Socotra have a high potential as 
local flagships to broaden awareness of aquatic habitat conservation, both towards the indigenous communities as well as visitors. In particular, the endemic and attractive Socotra Bluet is a flagship species to emphasize the importance of the pristine freshwater environments that sustain life on the island.

\subsection{Online resources}

To facilitate future dragonfly research on Socotra, the current list of 841 dragonfly records (also available as a spreadsheet in Supplementary Material) has been converted into a geodatabase and uploaded to a user-friendly simple web mapping server using the cloud service of ArcGIS online (ESRI). The online geodatabase is published using a web mapping application, accessible at www.dragonflie sofsocotra.com. When opening the application, the first layer shows the distribution of the first species in the alphabetical list, Anax imperator. Other species can be accessed by using the 'Layers' pictogram shown on the bottom of the screen. Clicking on any distribution point in the map gives the user access to the full details of the record and a link to a photo of each species. The top right of the app contains general information under the icon ' $i$ ' and a ruler icon to allow distance measurements and calculate areas. The mapping server is open access and connected to a mobile application, allowing the collection of new records in the field to achieve continuity and growth of the geodatabase.

\section{Conclusions}

1. We recorded relatively more Odonata in the east of Socotra Island which harbours most permanent wet areas with up to 17 taxa per $5 \times 5 \mathrm{~km}$. These areas can be considered as important for aquatic biodiversity. In the west, we recognized two areas with relatively important richness, but more surveys are needed.

2. Our analysis suggests a drop in dragonfly richness in areas in the Hadiboh Plain when comparing the records of 1896-1956 with those until 2019 (no records were available for the period 1957-1987). We attribute the change predominantly to human disturbance of aquatic and terrestrial habitats due to the effects of urbanization and vegetation loss. These areas still harbour a locally relatively high dragonfly richness and are priority sites for conservation. Other priority areas are those identified herein with high dragonfly richness in the mountains and on the plateaus.

3. Without intervention, a further decline of aquatic invertebrate diversity can be predicted on Socotra island, in particular in the northern coastal areas.
4. The potential of dragonflies as local flagship species to promote awareness for aquatic habitats and their conservation on Socotra is significant. Indigenous communities on the island perceive these insects as neutral to positive and recognise them as indicators of clean water. We identified at least six terms for the word 'dragonfly' in the unique Socotri language.

5. A new record of an Oriental Anax brings the total number of species known from the archipelago to 22, of which one is locally extinct and three have been recorded only once. The new record should be treated with care; however more vagrants can be expected. Continued and more systematic surveys, including local training, are needed to fill in the blanks and to continue to monitor the status of the Socotran Odonata and their habitats.

Electronic supplementary material The online version of this article (https://doi.org/10.1007/s12210-020-00942-6) contains supplementary material, which is available to authorized users.

Acknowledgements The authors wish to thank the Environmental Protection Agency (EPA) Yemen/Socotra Branch and the Ministry of Water and Environment Yemen, for supporting field work on Socotra; the entire study, collections and fieldwork, were conducted in agreement with EPA. Dr. Jan Bezděk and Dr. Jiří Hájek for various help, providing additional literature, in particular Dr. Hájek's valuable comments on parallels with the aquatic beetles; Dr. Wolfgang Wranik for help in mapping the original localities of his collection. Special thanks to Socotra island conservationists Salem Hamdiah (EPA) and Ali Yahia Mahroos for collecting notes on the local naming and impressions of dragonflies with KVD in 2019-2020. RK and JB wish to thank the Uyttenbogaart-Eliasen Foundation for financial support (SUB2008.12.02 and SUB2010.05.09) and Rob Felix and Ron Felix for their company and assistance in the field. The study was partly supported by the United Nations Environment Programme (UNEP) - Global Environment Facility (GEF) Project \#5347 for KVD and AS. Thanks to Dr F. Krupp for facilitating the biodiversity survey of KVD to Socotra in 2019. Special thanks to Paul Schrijvershof, Mark Eising and John Wilkinson for photographs of specimens from Oman, South Africa and Madagascar, for which we lacked photos from Socotra. Finally, the authors wish to thank the three reviewers, Geert De Knijf, Jiří Hájek and Elisa Riservato for valuable and constructive comments.

\section{Compliance with ethical standards}

Conflict of interest This study is in compliance with ethical standards and there is no conflict of interest.

Ethical standards All data are publicly available at the Socotra Dragonfly Portal (www.dragonfliesofsocotra.com). All data were compiled through this study and provided as raw data in the supplementary material. All distribution data have been shared with the Yemeni Government through EPA, including the Socotra Dragonfly Portal, temporarily hosted at Mendel University (Czech Republic). Dragonfly data was also provided by KVD to the SGN Socotra Portal. The study was partly supported by the United Nations Environment Programme (UNEP)—Global Environment Facility (GEF) Project \#5347 "Support to the Integrated Program for the Conservation and Sustainable 
Development of the Socotra Archipelago" for KVD and AS, and the Uyttenbogaart-Eliasen Foundation for RK and JB (SUB2008.12.02 and SUB2010.05.09).

Funding Open Access funding enabled and organized by Projekt DEAL.

Open Access This article is licensed under a Creative Commons Attribution 4.0 International License, which permits use, sharing, adaptation, distribution and reproduction in any medium or format, as long as you give appropriate credit to the original author(s) and the source, provide a link to the Creative Commons licence, and indicate if changes were made. The images or other third party material in this article are included in the article's Creative Commons licence, unless indicated otherwise in a credit line to the material. If material is not included in the article's Creative Commons licence and your intended use is not permitted by statutory regulation or exceeds the permitted use, you will need to obtain permission directly from the copyright holder. To view a copy of this licence, visit http://creativecommons.org/licenses/by/4.0/.

\section{References}

Al-Safadi MM (1998) Freshwater fishes of Soqotra Island, Yemen. In: Dumont HJ (Ed) Soqotra: proceedings of the first international symposium on soqotra island: present \& future, United Nations Publications, New York, pp 213-217

Apel M, Brandis D (2000) A new species of freshwater crab (Crustacea: Brachyura: Potamidae) from Socotra Island and description of Socotrapotamon n. gen. Fauna of Arabia 18:133-144

Banfield LM, Van Damme K, Miller AG (2011) Evolution and biogeography of the flora of the Socotra archipelago (Yemen) In: Bramwell D, Caujapé-Castells J (Eds), The Biology of Island Floras, Cambridge University Press, Cambridge, pp 197-225

Batelka J (2012) Socotra archipelago-a lifeboat in the sea of changes: advancement in Socotran insect biodiversity survey. Acta Ent Mus Nat Pra 52(suppl. 2):1-26

BBC News (2013) Exotic wildlife join HMS Echo crew. BBC News 9 Oct 2013, URL: https://www.bbc.com/news/uk-england-devon $-24456213$

Belyshev BF, Haritonov AY (1978) The distribution of the cosmopolitan genus Anax Leach and its probable origin (Anisoptera: Aeshnidae). Odonatologica 7:115-121

Beydoun ZR, Bichan HR (1970) The geology of Socotra, Gulf of Aden. Quart J Geol Soc Lond 125:413-446

Bezdĕk J, Hájek J (2017) Insect biodiversity of the Socotra Archipelago-underlined and counted. Act Ent Mus Nat Pra 57(Suppl):1-39

Bezděk J, Purchart L, Král K, Hula V (2012) List of local Socotran geographical names used in entomological literature. Act Ent Mus Nat Pra 52(Suppl. 2):27-67

Botting D (1959) Island of the Dragon's blood. Funk \& Wagnalls, New York, p 251

Boudot JP (2015) Ischnura senegalensis (Rambur, 1842). In: Boudot JP, Kalkman VJ (eds) Atlas of the European dragonflies and damselflies. KNNV publishing, The Netherlands, pp 137-139

Boudot JP, Clausnitzer V Dijkstra KDB, Suhling F, Schneider W, Samraoui B (2016a) Ceriagrion glabrum. The IUCN Red List of Threatened Species 2016: e.T59828A75380384.https://doi. org/10.2305/IUCN.UK.2016-3.RLTS.T59828A75380384.en. Downloaded on 13 February 2020
Boudot JP, Clausnitzer V Dijkstra KDB, Suhling F, Schneider W, Samraoui B (2016b) Paragomphus genei. The IUCN Red List of Threatened Species 2016: e.T59976A83861834.https://doi. org/10.2305/IUCN.UK.2016-3.RLTS.T59976A83861834.en. Downloaded on 13 February 2020

Boudot JP, Clausnitzer V Dijkstra KDB, Suhling F, Schneider W, Samraoui B (2016c) Rhyothemis semihyalina. The IUCN Red List of Threatened Species 2016: e.T60037A83869229.https:// doi.org/10.2305/IUCN.UK.2016-3.RLTS.T60037A83869229 .en. Downloaded on 13 February 2020

Boudot JP, De Knijf G (2015) Zygonyx torridus (Kirby, 1889). In: Boudot JP, Kalkman VJ (Eds): Atlas of the European dragonflies and damselflies. KNNV publishing, The Netherlands, pp $321-322$

Boudot JP, De Knijf G (2015) Zygonyx torridus (Kirby, 1889). In: Boudot JP, Kalkman VJ (eds) Atlas of the European dragonflies and damselflies. KNNV publishing, The Netherlands, pp 321-322

Boudot JP, Kalkman VJ (2015) Atlas of the European dragonflies and damselflies. KNNV publishing, The Netherlands, p 360

Carter M (2006) The land that time forgot. The Guardian, Yemen Observer section, April 13, 2006.URL: https://www.theguardia n.com/travel/2006/apr/16/yemen.observerescapesection

Cheung C, DeVantier L (2006) Socotra-a natural history of the islands and their people. Van Damme K (Ed) Odyssey books and guides. Airphoto International Ltd., Hong Kong, p 408

Clark TE, Samways MJ (1996) Dragonflies (Odonata) as indicators of biotope quality in the Kruger National Park, South Africa. J Appl Ecol 33:1001-1012

Clausnitzer V, Dijkstra KDB, Kipping J (2011) Globally threatened dragonflies (Odonata) in Eastern Africa and implications for conservation. J East Afr Nat Hist 100(1-2):89-111

Clausnitzer V (2016a) Crocothemis erythraea. The IUCN red list of threatened species 2016:e.T59859A83846274. https://doi. org/10.2305/IUCN.UK.2016-3.RLTS.T59859A83846274.en. Downloaded on 13 February 2020

Clausnitzer V (2016b) Tramea limbata. The IUCN red list of threatened species 2016: e.T60050A83381971. https://doi.org/10.2305/ IUCN.UK.2016-3.RLTS.T60050A83381971.en. Downloaded on 13 February 2020

Clausnitzer V, Jödicke R (2004) Guardians of the watershed. Int J Odonatol 7:111-112

Clausnitzer V, Martens A (2004) Critical species of Odonata in the Comoros, Seychelles, Mascarenes and other small western Indian Ocean islands. Int J Odonatol 7:207-218

Darwall WRT, Smith KG, Allen DJ, Holland RA, Harrison IJ, Brooks EGE (Eds) (2011) The diversity of life in african freshwaters: under water, under threat. An analysis of the status and distribution of freshwater species throughout mainland Africa. IUCN, Cambridge, Gland, p $347(+4)$

Dijkstra KDB, Clausnitzer V (2014) The dragonflies and damselflies of Eastern Africa. Handbook for all Odonata from Sudan to Zimbabwe. Studies in Afrotropical Zoology, vol. 298. Tervuren, Royal Museum for Central Africa, Belgium, p 263

Doe B (1992) Socotra: island of tranquility. In: Serjeant RB, RadcliffeSmith A, Guichard KM (eds) Immel Publishing Limited, London, p 219

Dolný A, Bárta D, Lhota S, Rusdianto DP (2011) Dragonflies (Odonata) in the Bornean rain forest as indicators of changes in biodiversity resulting from forest modification and destruction. Trop Zool 24:63-86

Dow RA, Clausnitzer V (2016) Diplacodes lefebvrii. The IUCN red list of threatened species 2016:e.T59864A83847795. https://doi. org/10.2305/IUCN.UK.2016-3.RLTS.T59864A83847795.en. Downloaded on 13 February 2020

Dow RA, Boudot JP, Clausnitzer V, Suhling F, Ferreira S, Dijkstra KDB, Schneider W, Samraoui B (2016) Zygonyx torridus. The 
IUCN red list of threatened species 2016: e.T60078A83877723. https://doi.org/10.2305/IUCN.UK.2016-3.RLTS.T60078A838 77723.en. Downloaded on 13 February 2020

Dumont HJ (1991) Odonata of the Levant. Fauna Palestine, Insecta V, Jerusalem, pp 297

Dumont HJ, Vierstraete A, Vanfleteren JR (2010) A molecular phylogeny of the Odonata (Insecta). Syst Entomol 35:6-18

Fikáček M, Delgado JA, Gentili E (2012) The hydrophiloid beetles of Socotra Island (Coleoptera: Georissidae, Hydrophilidae). Acta Ent Mus Nat Pra 52(Suppl. 2):107-130

Hájek J, Bezděk J (2019) Annotated catalogue of beetles (Coleoptera) of the Socotra Archipelago. Zootaxa 4715:1-76

Hájek J, Reiter A (2014) Adephagous water beetles (Coleoptera: Gyrinidae, Haliplidae, Noteridae, Dytiscidae) from Yemen and Dhofar region (Oman) with description of a new Hyphydrus from Socotra Island. Acta Ent Mus Nat Pra 54(Suppl):63-99

Hijmans RJ, Guarino L, Cruz M, Rojas E (2001) Computer tools for spatial analysis of plant genetic resources data: 1. DIVA-GIS Plant Genet Resour Newsl 127:15-19

IUCN World Heritage Outlook (2017) Socotra archipelago-2017 conservation outlook assessment, pp 32. URL: https://worldherit ageoutlook.iucn.org (date Accessed 30 Jan 2020)

Jödicke R, Boudot J-P, Jacquemin G, Samraoui B, Schneider W (2004) Critical species of Odonata in northern Africa and the Arabian Peninsula. Int J Odonatol 7:239-253

Kalkman VJ (2015) Orthetrum sabina (Drury, 1773). In: Boudot JP, Kalkman VJ (eds) Atlas of the European dragonflies and damselflies. KNNV publishing, The Netherlands, pp 283-285

Kalkman VJ, De Knijf G (2015) Diplacodes lefebvrii (Rambur, 1842) In: Boudot JP, Kalkman VJ (Eds): Atlas of the European dragonflies and damselflies. KNNV publishing, The Netherlands, pp 256-258

Kalkman VJ, Monnerat C (2015a) Anax ephippiger (Burmeister, 1839). In: Boudot JP, Kalkman VJ (Eds): Atlas of the European dragonflies and damselflies. KNNV publishing, The Netherlands, pp 169-171

Kalkman VJ, Monnerat C (2015b) Orthetrum chrysostigma (Burmeister, 1839). In: Boudot JP, Kalkman VJ (Eds): Atlas of the European dragonflies and damselflies. KNNV Publishing, The Netherlands, pp 278-279

Kalkman VJ, Monnerat (2015c) Pantala flavescens (Fabricius, 1798). In: Boudot JP, Kalkman VJ (Eds) Atlas of the European dragonflies and damselflies. KNNV publishing, The Netherlands, pp 291-298

Kalkman VJ, Proess R (2015) Anax imperator Leach, 1815. ). In: Boudot JP, Kalkman VJ (eds) Atlas of the European dragonflies and damselflies. KNNV publishing, The Netherlands, pp 173-175

Kalkman VJ, Clausnitzer V, Dijkstra KDB, Orr AG, Paulson DR, van Tol J (2008) Global diversity of dragonflies (Odonata) in freshwater. Hydrobiologia 595:351-363

Kimmins DE (1960) The odonata and neuroptera of the island of socotra. Ann Mag Nat Hist 13:385-392

Krupp F, Schneider W, Nader IA, Khushaim O (1990) Zoological survey in Saudi Arabia, spring. Fauna of Saudi Arabia 11:3-9

Lambret P, Boudot JP (2013) Hemianax ephippiger (Burmeister, 1839) (Odonata, Anisoptera: Aeshnidae): présentation générale. Martinia, Revue scientifique de la Société française d'Odonatologie, Hors série 2013:13-28

Lambret P, Boudot JP, Chelmick D, De Knijf G, Durand E, Judas J, Stoquert A (2017) Odonata surveys 2010-2016 in the United Arab Emirates and the Sultanate of Oman, with emphasis on some regional heritage species. Odonatologica 46:153-205

Lavergne E, Zajonz U, Krupp F, Naseeb F, Aideed MS (2016) Diversity and composition of estuarine and lagoonal fish assemblages of Socotra Island, Yemen. J Fish Biol 88:2004-2026

Lemelin RH (2007) Finding beauty in the dragon: the role of dragonflies in recreation and tourism. J Ecotour 6:139-145
May ML (2002) Phylogeny and taxonomy of the damselfly genus Enallagma and related taxa (Odonata: Zygoptera: Coenagrionidae). Syst Entomol 27:387-408

May ML (2019) Odonata: who they are and what they have done for us lately: classification and ecosystem services of dragonflies. Insects 10:62

McLachlan R (1903) Insecta: Neuroptera. Amphibiotica. In: Forbes HO (Ed) The natural history of Sokotra and Abd-el-Kuri: being the report upon the results of the conjoint expedition to these islands in 1898-9. Special Bulletin of the Liverpool Museums, Liverpool, pp 398-405. pls XXIV-XXIVa

McLachlan R, Kirby WF, Austen EE (1898) Insects of other orders. In: Dixey FA, Burr M, Pickard-Cambridge O (eds) On a collection of insects and arachnids made by Mr. E. N. Bennett in Socotra, with descriptions of new species. Proc Zool Soc Lond 1898:386-387

Miller A, Morris M (2004) Ethnoflora of the Soqotra Archipelago. Royal Botanical Gardens of Edinburgh, Edinburgh, p 759

Nasher AK, Al Jumaily MM (2003) Zoological material from Socotra Archipelago deposited in Sana'a University, with reference to the need for establishing a National Scientific Museum. In: BaAngood SA, Ba-Saleem MO, Hussein MO (eds) Proceedings of the second international symposium on the developing strategy of Socotra Archipelago and other Yemeni islands. 14-16 December 2003, Aden. Volume I. Natural resources and biodiversity. Aden University Printing and Publishing House, Aden, pp 65-73

Neubert E, Amr Z, Van Damme D (2014) The status and distribution of freshwater molluscs in the Arabian Peninsula. In: Smith KG, Barrios V, Darwall WRT, Numa C (eds) The status and distribution of freshwater fauna in Arabia. IUCN: Gland, Cambridge, pp 30-38

Pietsch D, Morris M (2010) Modern and ancient knowledge of conserving soils in Socotra Island, Yemen. In: Zdrulli et al. (eds) Land degradation and desertification: assessment, mitigation and remediation. Springer, Dordrecht, pp 374-386

Pinhey E (1970) Monographic study of the genus Trithemis Brauer (Odonata, Libellulidae). Mem Entomol Soc South Afr 11:1-259

Pinkert S, Dijkstra KDB, Zeuss D, Reudenbach C, Brandl R, Hof C (2017) Evolutionary processes, dispersal limitation and climatic history shape current diversity patterns of European dragonflies. Ecography 40:1-10

Porter RF (2011) Introducing the dragonflies on Socotra. Tayf 8:11

Porter RF, Suleiman AS (2016) The important bird and biodiversity areas of the socotra archipelago, Yemen. Sandgrouse 38:169-191

Ramsar (2013) Detwah Lagoon, Socotra Archipelago, Yemen. URL: https://rsis.ramsar.org/ris/1736?language=en (date Accessed: 30 Jan 2020)

Razzetti E, Sindaco R, Grieco C, Pella F, Ziliani U, Pupin F, Riservato E, Pellitteri-Rosa D, Butikofer L, Suleiman AS, Al-Aseily BA, Carugati C, Boncompagni E, Fasola M (2011) Annotated checklist and distribution of the Socotran Archipelago Herpetofauna. Zootaxa 2826:1-44

Remsburg AJ, Turner MG (2009) Aquatic and terrestrial drivers of dragonfly (Odonata) assemblages within and among north-temperate lakes. Freshw Sci 28:44-56

Riservato E, Grieco C, Pella F, Sindaco R, Pupin F, Suleiman AS, Fasola M (2010) A contribution to the knowledge of the odonatofauna of the Socotra Archipelago (Yemen) (Insecta: Odonata). Zool Middle East 50:101-106

Samraoui B, Weekers PHH, Dumont HJ (2002) Enallagma of the Western and Central Palaearctic (Zygoptera: Coenagrionidae). Odonatologica 31:371-381

Samraoui B, Boudot JP, Ferreira S, Riservato E, Jović M, Kalkman VJ, Schneider W (2010) The Status and Distribution of Dragonflies. In: García N, Cuttelod A, Abdul Malak D (eds) The status and distribution of freshwater biodiversity in Northern Africa. IUCN, Gland, Cambridge, Malaga, pp 51-70

Samways MJ (2003a) Conservation of an endemic odonate fauna in the Seychelles archipelago. Odonatologica 32:177-182 
Samways MJ (2003) Threats to the tropical island dragonfly fauna (Odonata) of Mayotte, Comoro archipelago. Biodivers Conserv 12:1785-1792

Samways MJ, Pryke JS, Simaika JP (2011) Threats to dragonflies on land islands can be as great as those on oceanic islands. Biol Conserv 144:1145-1151

Samways MJ, Simaika JP (2016) Manual of freshwater assessment for South Africa: Dragonfly Biotic Index. South African National Biodiversity Institute (SANBI). Pretoria, Suricata 2:1-224

Schneider T, Ikemeyer D (2016) Dragonflies of Oman-a revised illustrated checklist (Odonata). Entomologische Zeitschrift Schwanfeld 126:137-147

Schneider W (1999) Soqotra-the island of dragons' blood. Agrion 3:27-28

Schneider W, Dumont HJ (1998) Checklist of the dragonflies and damselflies of Soqotra Island (Insecta: Odonata). In: Dumont HJ (ed) Proceedings of the First international symposium on Soqotra Island: Present and future. Volume 1. United Nations Publications, New York, pp 219-231

Schneider W, Nasher AK (2013) Dragonflies from mainland Yemen and the Socotra Archipelago-additional records and novelties. Int Drag Fund Rep 57:1-13

Schneider W, Parr MJ (1998) Orthetrum julia falsum Longfield 1955, new to the dragonfly fauna of Yemen and the Arabian Peninsula (Anisoptera: Libellulidae). Int J Odonatol 1:155-158

Schneider W, Samraoui B (2015) The status and distribution of dragonflies and damselflies (Odonata) in the Arabian Peninsula. In: García N, Harrison I, Cox N, Tognelli MF (eds). Freshwater biodiversity in the arabian peninsula. IUCN, Gland, Cambridge, Arlington, pp 39-55

Schneider W, Samraoui B, Boudot J-P (2013) Azuragrion somalicum ssp. amitinum. The IUCN Red List of Threatened Species 2013: e.T13186344A13186346. https://doi.org/10.2305/IUCN. UK.2013-1.RLTS.T13186344A13186346.en. Downloaded on 30 January 2020

Schneider W, Samraoui B, Boudot J-P (2018) Azuragrion granti. The IUCN Red List of Threatened Species 2018: e.T60286A75346501. https://doi.org/10.2305/IUCN.UK.2018-1. RLTS.T60286A75346501.en. Downloaded on 30 January 2020

Scholte P, De Geest P (2010) The climate of Socotra Island (Yemen): a first-time assessment of the timing of the monsoon wind reversal and its influence on precipitation and vegetation patterns. J Arid Environ 74:1507-1515

Sharma G (2013) Macrodiplax cora. The IUCN red list of threatened species 2013: e.T167478A17531208. https://doi.org/10.2305/ IUCN.UK.2013-1.RLTS.T167478A17531208.en. Downloaded on 13 February 2020

Simaika JP, Samways MJ (2009) An easy-to-use index of ecological integrity for prioritizing freshwater sites and for assessing habitat quality. Biodivers Conserv 18:1171-1185
Sohlman E (2004) A Bid to Save the 'Galápagos of the Indian Ocean'. Science 303(5665): 1753

Thieme ML, Abell R, Burgess N, Lehner B, Dinerstein E, Olson D (2005) Freshwater ecoregions of africa and madagascar: a conservation assessment. Island Press, Washington DC, p 483

Tobias MC, Morrison JG (2008) Sanctuary: global oases of innocence. Council Oak Books, Tulsa, p 360

UNDP/GEF (2000) Socotra biodiversity project YEM/96/G32. Conservation Zoning Plan of Socotra Islands. Presidential Decree no. 275 of the Year 2000, p 17 URL: https://www.friendsofsoqotr a.org/Bibliography/pdfs/Zoning\%2520plan\%25202000.pdf

UNEP/WCMC (2008) Socotra Archipelago, Yemen. UNESCO Fact Sheet. World heritage sites, protected areas and world heritage. United Nations Environment Programme and World Conservation Monitoring Centre, 11 pp. URL: www.unep-wcmc.org/sites/wh/ pdf/Socotra\%2520revised.pdf

Van Damme K (2009) Socotra Archipelago. In: Gillespie RG, Clague DA (eds) Encyclopedia of Islands. University of California Press, Berkeley, Los Angeles, pp 846-851

Van Damme K (2011) Insular biodiversity in a changing world. Nature Middle East 2011:61. https://doi.org/10.1038/nmiddleeas t.2011.61

Van Damme K (2018) A record of Notostraca on Socotra Island and the importance of local conservation of the habitat. Zootaxa 4446:555-566

Van Damme K, Banfield L (2011) Past and present human impacts on the biodiversity of Socotra Island (Yemen): implications for future conservation. Zool Middle East 2011(Suppl. 3):31-88

Villalobos-Jiménez G, Dunn AM, Hassall C (2016) Dragonflies and damselflies (Odonata) in urban ecosystems: a review. Eur J Entomol 113:217-232

Walpole JM, Leader-Williams N (2002) Tourism and flagship species in conservation. Biodivers Conserv 11:543-547

Waterston AR, Pittaway AR (1991) The Odonata or dragonflies of Oman and neighbouring territories. J Oman Stud 10(989):131-168

Wewalka G (2004) Dytiscidae (Insecta: Coleoptera) of the Socotra Archipelago, with descriptions of two new species. Fauna of Arabia 20:463-472

Wranik W (1998) Faunistic notes on Soqotra Island. In: Dumont HJ (ed) Proceedings of the First international symposium on Soqotra Island: Present and future. Volume 1. United Nations Publications, New York, pp 135-198

Wranik W (2003) Fauna of the socotra archipelago. Field guide. Universität Rostock, Rostock, p 542

Publisher's Note Springer Nature remains neutral with regard to jurisdictional claims in published maps and institutional affiliations. 